\title{
Experimental Study of Plastic Responses of Pipe Elbows
}

\author{
W. L. Greenstreet
}

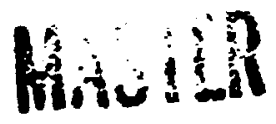

Prepared for the U.S. Nuclear Regulatory Commission Office of Nuclear Regulatory Research Under Interagency Agreements ERDA 40-551-75 and 40-552-75 
ORNL/NUREG-24

Dist. Category NRC-5

Contract No. W-7:05-eng-26

Ẽngjneering Tech

EXPERIMENTAL STUDY OF PLAS'IIC RESPONSES OF PIPE ELBOWS

W. L. Greenstreet

Manuscript completed - January 20, i978

Date Published: February 1978

Prepared for the

U.S. Nuclear Regulatory Commission

office of Nuclear Regulatory Research under Interagency Agreements F.RDi 40-551-75 and 40-552-75

Prepared by the

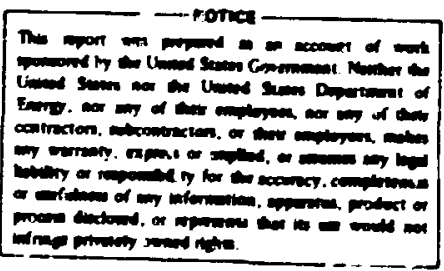

OAK RIDGE NATIONAL LABORATORY

Oak RIdge, Tennessee 37830

operated by

UNION CARBIDE CORPORATION

for the

LEPARTMENT OF' ENERGY 


\section{CONTFNTS}

Page

FOREWORD ........................... . v

ABSTRACT . . . . . . . . . . . . . . . . 1

INTRODUCTION . . . . . . . . . . . . . . . . 1

DESCRIPTION OF SPECIMENS AND TESTS . . . . . . . . . . 3

EXPERIMENTAL RESULTS . . . . . . . . . . . 15

INTERPRETATION OF RESULTS . . . . . . . . . . . 35

CONCLUSIONS . . . . . . . . . . . . . . . . . 47

ACKNOWLEDGMENT . . . . . . . . . . . . . . . 48

REFERENCES . . . . . . . . . . . . . . . . 48

APPENDIX: DIMENSIONAL DATA FOR SPECIMENS PE-17 THROUGH -20 . . 51 


\section{FOREWORD}

This work was performed at th= Oak Ridge National Laboratory (ORNL) in support of the JRNL Design Criteria for Piping and Nozzles Program being conducted for the U.S. Niclear Regulatory Commisston (USNRC), Jffice of Nuclear Reguiatory Research. E. K. Lynn of the Metallurgy and Materials Branch, Division of Reactor Safety Research, USNRC, is tie cognizant engineer, and S. F. Moore of ORNL Engineering Technology Division is the program manager.

The objectives of the ORNL program are to conduct integrated experimental and analytical stress analysis studies of piping system components .1nd pressure vessel nozzles to confirm and/or impro'e the adequacy of structural design criteria and analytical methods used to assure that nuclear power plants are designed for safe operation. Program activities are coordinated with other safety-related piping and pressure vessel research through the Design Division, Pressure Vessel Fasearch Committee (PVRC) of the Welding Research Counc11, and through the ASME Boiler and Pressure Vessel Code committees. Results from the ORNL program are used by appropriate codes and standards groups in drafting new or improved design rules and criteria.

The following reports have been issued under U.S. Nuclaar Regulatory Commission sponsorship:

J. W. Bryson, J. P. Callatan, and R. C. Gwaltney, Stress Analydes of Flat Flates with Attashed Nozzles, Vol. 1. Comparison of Stresses in o One-Nozale-to-Flat-Plate Configuration and in a Two-iozale Corfiguration with Theoretical Predictions, ORNL-5044 (July 1975).

R. L. Battiste et al., Stress Analysis of Flat Plates with Attached Nozales, Vol. 2. Experimental Stress Analyses of a Fiat Plate with une Nozile Attached, ORNL-5044 (July 1975).

E. C. Rodabaugh and S. E. Moore, Stress Indices for ANSI Standard B16.11 Socket-Welding Fittings, ORNL/TM-4929 (August 1975).

R. C. Gialtney, J. W. Brysen, and S. E. Bolt, Theoretical and Experimental Stress Analyses of OQNL Thin-Shell Cylinder-tc-Cylinder Model 2, ORNI,-5021 (Occober 1975). 
S. E. Moore, "Cont; . utinns of the ORML "iping Progran to Nuclear Plping Design Code. and Standards," Proveedings of the Technology Information Meetin, on "iethods for Analysing Piping Integrity, Nov. 11-12, 1975, PDA-.6-50; also in J. Tres8. Vessel Technoi., Trans. ASME 99, 22;-30 (February i977).

H. L. Greenstreet, "Sumary and Accouplistiments of the ORNL Program for Nuclear Piping Design Criteria," Procsedings of the Technology Information Meeting; on Methods for Analysing Piting Integrity, Nov. 11-12, 1975, E.RDA-76-50.

J. H. Bryson and H. F. Swinson, Itress Anx?yeee of tint, Plates with Attached Hozzles, V.Z. 3. Experimental S:ress Analyses of a Fi t Plate with Two Clos:ly Spaced Ncziles of iqual Diameter Attracie: ORNL-5044 (Decenber 1975).

E. C. Rouabaigh, F. H. O'Hara, Jr., and S. E. Woore, FLANGE: A Computer Proyrom for the Analysis of Flanged Joints with Ring-Type Gaskets, CakL-5035 (january 1976).

R. L. Texr.3r, User's suide for SHFA: Steady-State Heat F'ow Analysis of Tee Joi;sts by the Finite Element Method, UCCN//CSD/INF-60, Oak Ridge Gaseous Diffusion Plant (January 1976).

E. C. Podabaugh and S. E. More, Flanged Joirts with Contact Outside the Boin: Circle - ASM: Part B Design Rules, ORNL/Sub/2913-1. Battelle-Columbus Labcratories (May 1976).

E. C. Rodabaugh, Approj riate Nominal Streeses for Use with ASME Code Pressure-Loading Stress Indices jor Noz.3Les, ORNL/Sub/2913-2, Buttelle-Columbus Labor atorfes (June i976).

S. E. More and J. W. Bryson, Progress Report for the Design Criteria for Piping and Nozzles Program for the Two Quarterly Period: July 1 to Sept. 30 and Oct. 1 to Dea. 31, 1975, ORN/NUREG/TM-18 (June 1976).

R. L. Maxwe1l and R. W. Holland, Experimental Stress Analysie of the A'tachment Pegion of a Hemispherical Shell with a Radiall!, sitached Nozzle, Zeru Penetration, ORNL/Sub/2203-4, University of Tennessee (July 1976).

J. P. Cullahan and J. W. Bryson, Stress Aralyses of Perforated Fiat Plater. Under In-Plane Loadings, ORM/NUREG-2 (August 1976).

E. C. Rodabaugh and S. E. Moore, Evaluation of the nolting and Planges of ANSI B16.5 Flanged Joints - ASME Part A Elanges, ORNi,/Sub/2913-3, Battel le-Columbus Laboratories (September 1976).

F. C. Rodabaugh and R. C. Gwaltney, Elastic Stresses at Reinforced $\therefore$ ales in Sphorical Shells with Presoure and Menent Loading, or.?.:/Sub/2913-4, Battelle-Columbus Laboratories (October 1976). 
E. C. Rodabaugh, S. E. Moore, and J. N. Robinson, Eimensional Control of Buttwelding Pipe Fittirgs for Inclear Power $P^{7}$ mt Class ? Piping Systems, nun; Judi2313-5, Battelle-Columbus Labora zories (December 1976).

S. E. Moore and J. W. Bryson, Design Criteria jo Piping and llozises Progrum Quarterly Progress Rcjort for April-sine 1976, ORNL/NUREG/ TM-107 (April 1977).

E. C. Rodabaugh and S. E. Moore, Elexibility Factors for Small $(a / D<1 / 3)$ Branch Connections with External Loudings, ORNL!Sub/ 2913-6, Battelle-Columbus Laboratorles (March 1977).

S. E. Moore and J. W. Bryson, Desigr Criteria for Piping and lozzles Progrom Quarteriy Progress Report for July-September 197i, 0RNL/ NUREG/TM-91 (Febriary 1977).

P. G. Fowler and J. W. Bryson, User's Manual for the CJRTES Graphics Package GRFPAK, ORNL/NUREG/TM-127 (August 1977).

B. R. Bass, J. W. Bryson, and S. E. Moore, "Validation of the Finite Element Stress Analysis Computer Program CORTF.s-SA for Analyzing Piping Tees and Pressure Vessel Nozzles," Pressure iessels and Fiping Computer Program Evaluation and Qualification, PVP-PB-024, Pp. 9-25, ASME (1977).

J. K. Hayes and S. E. Moore, "Experimental Stress Analysis for Four 24-in. ANSI Standard B16.9 Tees," Paper 77-PVP-4, presented at the ASME Energy Technology Conference and Exhibition, Houston, Tex., Sept. 18-23, 1977.

I. W. Bryson, W. G. Johnson, and B. R. Bass, Stresses in Peinforced Nozale-Cylinds. Attachments Under Internal Fressure Loading Analuzed by the Finite-Element Method - A Parameter Study, ORNL/NUREG-4 (October 1977).

F. K. W. Tso et al., Stress Anaiysis of Cylindrical Pressure Vessels with Closely Spaced Vozzles by the Finite-Element Method, Vol. 1. Stress Analysis of Vesseis with two Closely Spaied Nozzles Inder Internal Pressure, ORNL/NUREG-18/V1 (November 1977). 


\title{
EXPERIMENTAL STUDY OF PLASTIC RESPONSES
}

OF PIPE ELBOWS

H. L. Greenstreet

\begin{abstract}
Load-deflection responses vere deterwined experinentally for sixteen 152.4-mom (6-in.) (nominal) comercial carbon steel pipe elbows and four 152.4-m (6-in.) stalnless steel elbows. Each speciven vas loaded with an external force of sufficient magnitude to produce predorinantly plastic response. The Influences of bend radius and wall thlikness were studied, as well as the effect of internal pressure on load-deflection behavior. innnartoons of results from stalnless steel and from carbon steel elbows indicate differences in respunses attributable to material differences. The results were incerpreted in terms of 1 imit analysis concepts, and collapse loads were deternined. Trends given by the collapse loads are identified and discussed.
\end{abstract}

\section{INTRODUCTION}

This report is concerned with the structural behavior of pipe elbows. These comonly used components are of particular importance because they are often the most flexible members in a piping system anci hence are forced to accommodate itsproport tonate displacements arising from differential movements. In practice, this flexibility is needed to keep the overall forces and stresses in the system within acceptable ranges. However, precautions must be taken to avoid exceeding the range of predoninantly elastic response because the resistance to deformation will decrease rapidly with increasing load and may result in malfunction or faflure of the component and of the system.

In orcer to avold these undesirable structural responses, plastic limit analysis concepts are used for establishing allowable loads. Limit acalyses provide estimates of plastic collapse loads, that 1s, loads above winch large increases in deformaticn result from small increases in load. These large deformations are assoclated with plastic flow, which dominates to such an extenc that the elastic portions of the material do not play a significant role in resisting the deformations. Although these concepts are associated with idealized behaviors adopted for use in mathematical 


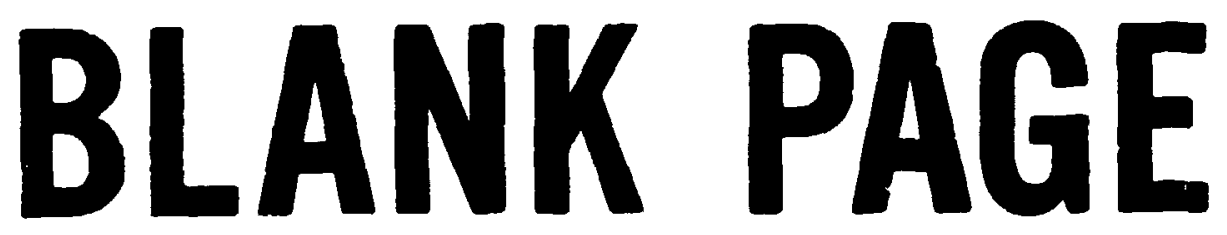


analyses, they can be applied to structures such as elbows provided that

1. excessive deformations occur before the influence of strain hardening becones appreciable;

2. changes in geonetry of the structure produced by the deflections have negligible effect on the load required to continue the deformation.

Experinentall; deternined plastic collapse loads are given in this report for 20 comercial short- and long-radius butt-welding elbows, nominally $152.4=$ (6 in.) In dianeter. These elbows were loaded by external forces and by concsetions of external force and internal pressure. Deflectfons and strains were measured by means of dial indicators and strain gages, respectively. The dial-indicator readings were the primary sources for lint-load deterrinations, and the strain-gage data were used for checking purposes and to provide details on the plastic collapse process.

The principal objective of this series of zests was to obtain inplane and out-of-plane limit moments. The imposed moments were produced by forces acting on moment arms sufficiently long to give essentially only moment loads on the elbows. The specimens were not examined to provide quantitative information regarding the locations and extents of the plastic zones developed or to determine the order in which such zones were formed. However, qualitative data regarding plastic zone location for selected reglons were obtained in a few instances.

The test specimen 3 and the experimental procedures a = described in the following sections. Representative load-deflection and load-strain curves are inclucied to indicate the results obtained, and the method used for IImit-load determination is explained. The limft loads are tabulated, and conclusions regarding the test rcsults are presented.

Results fiom the first 15 eloow tests were giver in Ris. 2. In this report, the contents are expanded to cover results from 5 additional tests, and the overall results are interpreted on the broader bases afforded by the added information. 


\section{DESCRIPTION OF SPECIMENS AND TESTS}

A series of room-temperature linit-loaj tests was conducted on twenty 152.4-m (5-in.) commercial butt-welding elbows. Sixteen were made from ASTM A-1OS grade B carbon steel, and four were made from ASTM A-312 type 304L stainless steel. Short- and long-radius sched-40 and -80 elbows were used. The first 16 were obtained from the same manufacturer; all types are listed in Table 1 along with the nowinal dimensions and materials properties. A typical opecimen is shown in Fig. 1.

Both types of elbcws were made using standard manufacturing procedures. The carbon stecl elbows were formed by forcing ASTM A-106, grade B, hot-finjshed seamless pipe over a mandrel in a furnace where the metal semperature was held within the approximate range of 871 to $982^{\circ} \mathrm{C}\left(1600\right.$ to $\left.1800^{\circ} \mathrm{F}\right)$. The formed pieces were then maintained at temperatures in the range quoted and inserted in sizing dies which are used to ensure conformance with the dimensional requirements of ANSI B16.9 and B16.28. Following the forming and sizing operations, the elbows were cooled in still air. The temperatures during fabrication and the method of cooling are in accord with the requircments of ASTM A-234, which does not require that further heat treatment be applied.

The stainless steel elbows were formed by forcing ASTM A-312 type 304L stafnless steel seamless pipe through a die cavity at room temperature. An inside mandrel was used in this operation to guide the pipe and to prevent buckling during the forming process. Following fabrication, the elbows were annealed at $1066^{\circ} \mathrm{C}\left(1950^{\circ} \mathrm{F}\right)$ and water quenched.

The majerials properties listed in Table 1 were obtalred mainly fron tensile specimens taken from selected elbows after they were tested. In some cases, specimens were taken from duplicate elbows; the first 16 elbows were from 4 lots, and one from each lot was used. The coupons for the tensile specimens were removed from the outside near the loaded end of each elbow; this region was subfected to relatively low strains during test in all cases. Tensile specimens from each of the last four spectliens were tested.

The tensile specimen.7 had a 3.18-mm-dtam (0.125-in.), 12.i-mm-1ong (1/2-in.) gage section and were instrumented with twic metallic-foll 


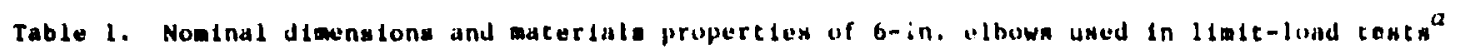

\begin{tabular}{|c|c|c|c|c|c|c|c|c|c|c|c|}
\hline \multirow[b]{2}{*}{ Specienne } & \multirow{2}{*}{ Deecription $b$} & \multicolumn{4}{|c|}{ Nowinal dimenslons } & \multirow{2}{*}{$\begin{array}{l}\text { Specimen } \\
\text { material }\end{array}$} & \multirow{2}{*}{$\begin{array}{l}\text { Lot } \\
\text { No. }\end{array}$} & \multirow{2}{*}{$\begin{array}{l}\text { Moduluy } \\
\text { ol eluatedey } \\
\left(p=1 \times 10^{-f_{2}}\right)\end{array}$} & \multirow{2}{*}{$\begin{array}{l}0.2 \% \text { offuet } \\
\text { yluld nerous } \\
\text { (pal) }\end{array}$} & \multirow{2}{*}{$\begin{array}{c}\text { irupretional } \\
\text { limit yiald } \\
\text { ntruen } \\
(p, 1)\end{array}$} & \multirow{2}{*}{$\begin{array}{l}\text { Tenulle } \\
\text { werength } \\
\text { (rub) }\end{array}$} \\
\hline & & $\begin{array}{l}D_{0} \\
(1,1 .)\end{array}$ & $\begin{array}{l}D_{i} \\
(\ln .)\end{array}$ & $\begin{array}{c}D_{t} \\
(\ln .)\end{array}$ & $D_{1} / \mathrm{c}$ & & & & & & \\
\hline$P E-1$ co -6 & Sched-40 LR & 6.625 & 6.015 & 0.280 & 21.66 & $\begin{array}{l}\text { Astis A-106 } \\
\text { grade B }\end{array}$ & $\$ 4401$ & 10.1 & 50,000 & & $: 1,600$ \\
\hline$P E-7 \quad 50-9$ & Sched-80 LR & 6.625 & 5.761 & 0.432 & 13.34 & $\begin{array}{c}\text { ASTM A-106 } \\
\text { xrade }\end{array}$ & $\$ 3147$ & $30 . ?$ & 37.800 & & 65.100 \\
\hline PE 10 to -14 & Sched-40 SR & 6.625 & 6.065 & 0.280 & 21.66 & $\begin{array}{l}\text { ASTM A-106 } \\
\text { Krade } \mathrm{B}\end{array}$ & $\$ 4521$ & 11.1 & 39,600 & & 74,100 \\
\hline$P E-15,-16$ & Sched-4C LR & 6.625 & 6.065 & $0.2 \mathrm{HO}$ & 21.66 & $\begin{array}{l}\text { ASTM A-312 } \\
\text { type } 3041 \text {. SS }\end{array}$ & SIP & 2н. Н & 37,700 & 13,500 & 67,800 \\
\hline$P E-17$ & Sched-40 SR & 6.625 & 0.065 & 0.280 & 21.66 & $\begin{array}{l}\text { ASTM } \lambda-312 \\
\text { Cype 304l. SS }\end{array}$ & $\begin{array}{r}14247 \\
\text { SSGW }\end{array}$ & 29.4 & 35,600 & $16,00(1)$ & $9 h, 6(1)$ \\
\hline$P E-18$ & Sched -80 LR & 6.625 & 5.761 & 0.432 & 13,34 & $\begin{array}{l}\text { ASTH } A-312 \\
\text { type } 304 \mathrm{~L} \text { SS }\end{array}$ & $\begin{array}{r}15526 \\
\text { SSAV }\end{array}$ & 29.7 & 15,400 & 18,000 & $8 x_{1} 100$ \\
\hline$P E-19$ & Sched-40 SR & 6.625 & 6.065 & 0.280 & 21.66 & $\begin{array}{l}\text { ASTT A-1U6 } \\
\text { Rrade B }\end{array}$ & $\begin{array}{l}\text { Heate No., } \\
\text { NSI 38? }\end{array}$ & 33.11 & 46.000 & & $68,0 !$ \\
\hline PE-20 & Sched-80 SR & 6.625 & 5.761 & 0.4 .2 & 13.34 & $\begin{array}{l}\text { AStM A-10b } \\
\text { arade B }\end{array}$ & & 28.4 & 34,600 & & 70,400 \\
\hline
\end{tabular}




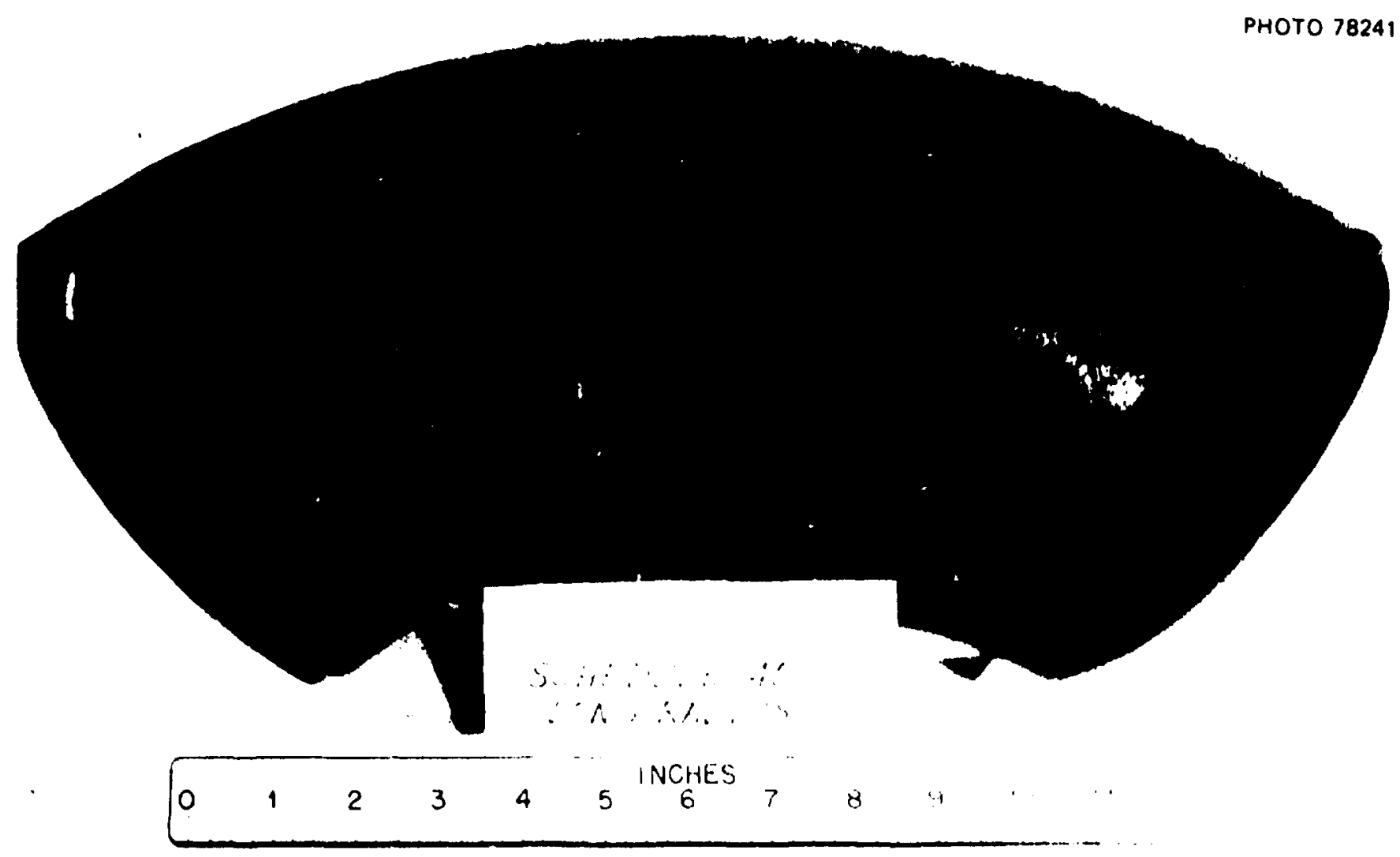

Fig. 1. Typlcal $25.4-\mathrm{mm}(6-\mathrm{In}$.) long-radius, carbon steel buttwelding elbow. 
electrical resistance strain gages having a 6.35 -mm (1/4-in.) gage length, except for eibows 17 chrough 20, which had a gage length of $3.18 \mathrm{~mm}$ $(1 / 8$ in.). The gages wer 2 mounted on opposite sides of the specimen with an epoxy adhesive and connected in series to average the strains. Thie platen rate was $0.051 \mathrm{~mm} / \mathrm{min}(0.002 \mathrm{in.})$. Thrte tensile specimens were tested for Iot S4401 (see Table 1) and elbows 17, 18, and 19; two tensile specimens were tested from lot SPFM and five for elbow 20 . Average values are given in the table.

Pipe extensions of ASTM A-106 grade B carbon steel of the same thickness as the elbow being tested were welded by the tungsten-arc inert-gas method to the ends of the albows. Elbow $P E-18$ was an exception in that 347 stainless steel extenstons were used. The assemblies were not heat treated following the welding operations, thus simulating metal conditions to be found in actual piping systems. One extension was then rigidly mounted on a pedestal attached to a load frame. A test setup is shown diagramatically in Fig. 2. A single force loading was applied in each case, with the point of load application on the free extension at a distance of four to five pipe diameters from the nearer end of the elbow. The loadings of interest were the moments at that end of the elbow; by selecting a relatively long moment arm, the shear force: were small in compaison with the moments. The distance from the other end of the elbow to the plane of restratnt (the top of the pedestal on the load frame) was about three pipe diameters.

The specimen numbers, wall thicknesses, bend radii, and loading conditions are listed in Table 2. For the specimens used, a bend radius of $152.4 \mathrm{~mm}$ ( $6 \mathrm{in.)}$ is termed short radius; $228.6 \mathrm{~mm}$ (9 in.) is long radius. In cases where the elbows were also internally pressurized, the specimens were held at the design pressure of $10.34 \mathrm{MPa}$ (1500 psi) throughout the test perfod. The moment sign convention is shown in Fig. 3 .

The locations of the dial Indicators used to measure deflections for 15 of the 16 carbon steel elbows and 3 of the 4 stainless steel elbows are Indicated In Fig. 2. Fo: carbon steel elbow PE-20, dial indicator DI 1 was at $254 \mathrm{~mm}(10 \mathrm{in.})$ and dial indicator DI 2 was at $381 \mathrm{~mm}$ (15 in.) from the end of the elbov. In the case of stainless steel elbow PE-15, two dial indicatore in addition to those shown in Fig. 2 were used to 


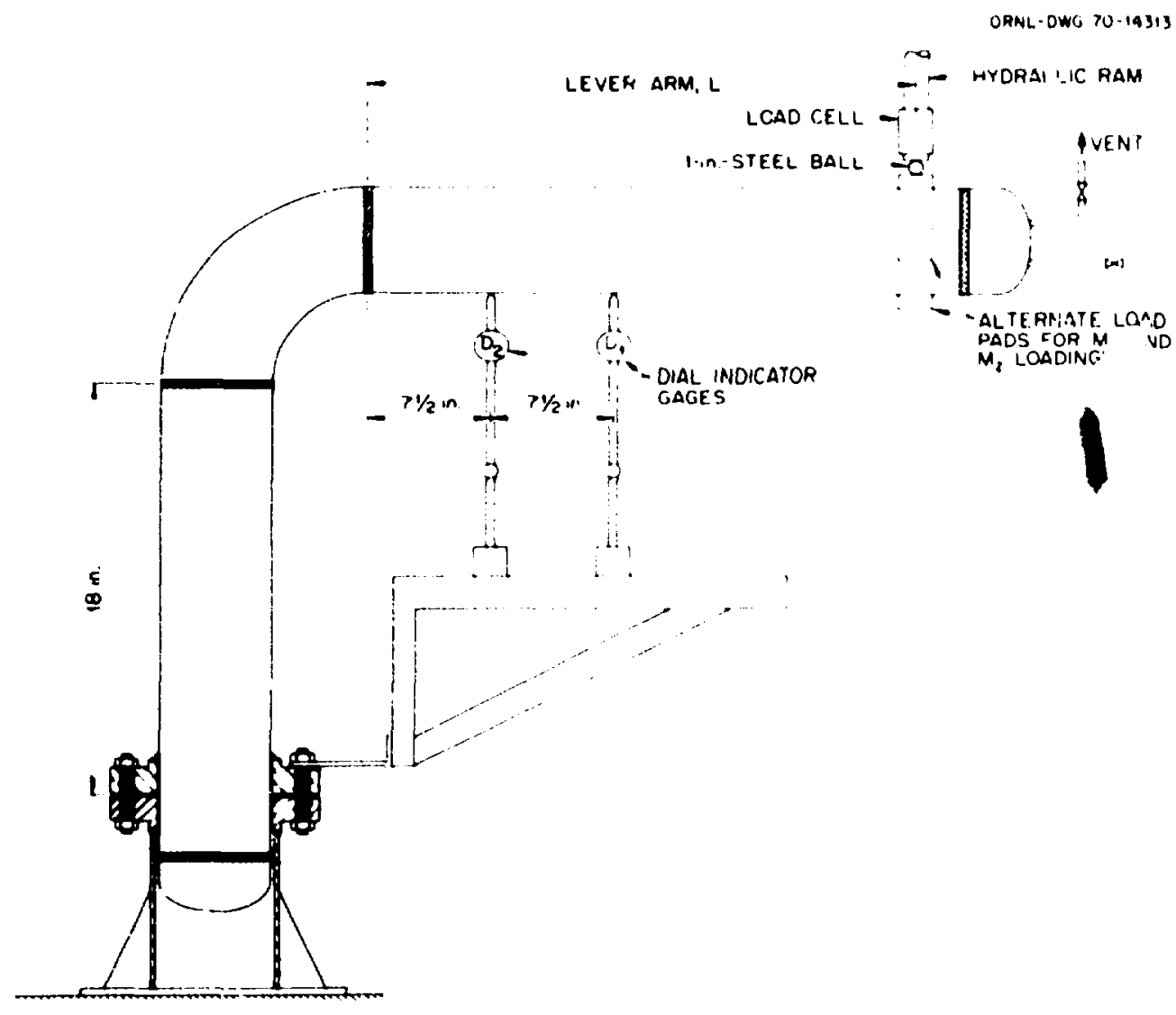

Fig. 2. Diagram of test setup $(1 \mathrm{in} .=25.4 \mathrm{~mm})$.

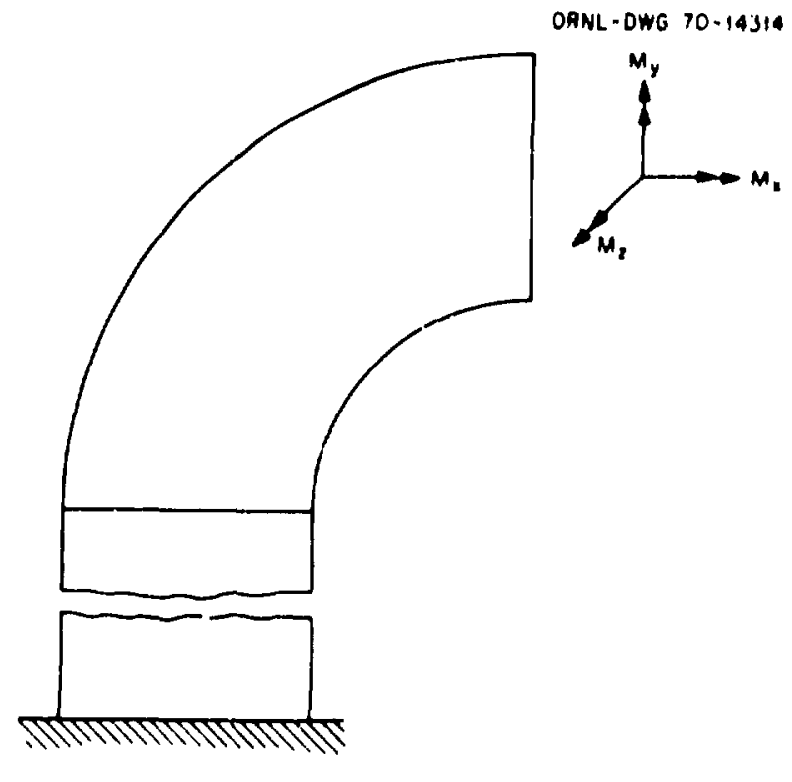

F18. 3. Dlagram of moment sign convention. 
Table 2. Plastic limlt load tests on 6-1n. elbows ${ }^{a}$

\begin{tabular}{|c|c|c|c|c|c|c|}
\hline & \multirow{2}{*}{\multicolumn{2}{|c|}{ Elbow }} & \multicolumn{4}{|c|}{ Loading conditions } \\
\hline & & & \multicolumn{3}{|c|}{ Howent ${ }^{c}$} & \multirow{3}{*}{$\begin{array}{c}\text { Pressure, } \\
\text { P }\end{array}$} \\
\hline \multirow[t]{2}{*}{ Number $b$} & \multirow{2}{*}{$\begin{array}{c}\text { Wall } \\
\text { thickness } \\
\text { (schedule) }\end{array}$} & \multirow{2}{*}{$\begin{array}{l}\text { Bend } \\
\text { radius } \\
\text { (in.) }\end{array}$} & \multicolumn{2}{|c|}{ In plane ${ }^{d}$} & Out of plane & \\
\hline & & & $+H_{2}$ & $-\mathrm{M}_{2}$ & $\mathrm{M}_{\mathrm{y}}$ & \\
\hline PE-1 & 40 & 9 & $\mathbf{x}$ & & & \\
\hline PE-2 & 40 & 9 & & $\mathbf{X}$ & & \\
\hline PE-3 & 40 & 9 & & & $\mathbf{X}$ & \\
\hline$P E-4$ & 40 & 9 & $\mathbf{x}$ & & & $\mathrm{X}$ \\
\hline PE-5 & 40 & 9 & & $\mathbf{x}$ & & $\mathrm{X}$ \\
\hline PE-6 & 40 & 9 & & & $\mathbf{X}$ & $\mathbf{X}$ \\
\hline PE-7 & 80 & 9 & $\mathbf{x}$ & & & \\
\hline PE-8 & 80 & y & & $\mathrm{x}$ & & \\
\hline PE-9 & 80 & 9 & & & $x$ & \\
\hline PE-10 & 40 & 6 & $\mathbf{x}$ & & & \\
\hline PE-11 & 40 & 6 & & $x$ & & \\
\hline PE-12 & 40 & 6 & & $A$ & $x$ & \\
\hline $\mathrm{PE}-13$ & 40 & 6 & $x$ & & & $x$ \\
\hline PE-14 & 40 & 6 & & & $\mathrm{X}$ & $\hat{x}$ \\
\hline $\mathrm{PE}-15^{e}$ & 40 & 9 & & $x$ & & \\
\hline$P E-16^{E}$ & 40 & 9 & & $\mathrm{x}$ & & \\
\hline $\mathrm{PE}-17^{e}$ & 40 & 6 & & $\mathrm{x}$ & & \\
\hline $\mathrm{PE}-18^{e}$ & 80 & 9 & & $\mathrm{X}$ & & \\
\hline PE-19 & 40 & 6 & & $\mathrm{X}$ & & \\
\hline PE-20 & 80 & 6 & & $\mathbf{x}$ & & \\
\hline
\end{tabular}

$a_{1}$ in. $=25.4 \mathrm{~mm}$.

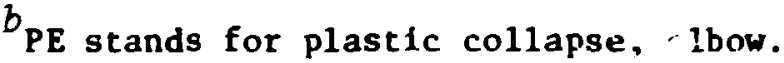

${ }^{c}$ See Fig. 3 for sign convention.

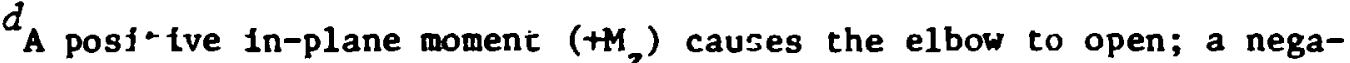
tive in-plane roment $\left(-H_{z}\right)$ causes the elbow to close'.

$e_{\text {Type }} 304 \mathrm{~L}$ stainless steel elbow.

obtain the vertical and horizontal displacements at the weld at the loaded end of the elbow. With the additional information provided. the rotation $\theta$ of the pipe extension in the plane of loading could be used In determining the collapse load. Forces were applied by hydraulic ram, and the gnitudes were measured using a strain-gage-based load cell.

F1gure 4 is a photograph of specimen PE-16 under test. 


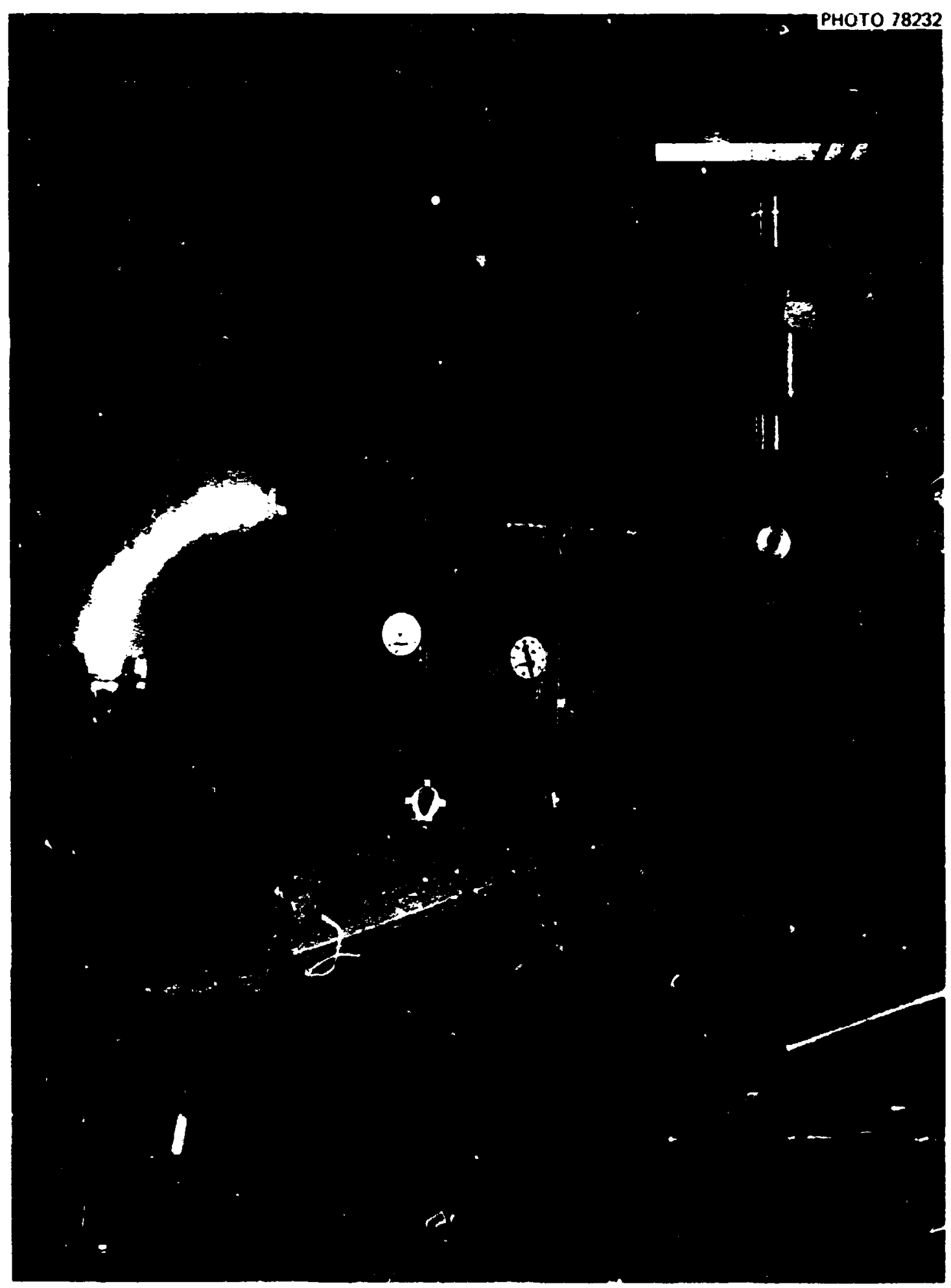

Fig, 4. Strinless steel elbow PE-16 during test. 
Strain gages were mounted on specimens $P E-1,-2,-3,-\delta,-10$, and -11 at the lr ations show in Fig. 5. Single-element, bonded metallicfoll, electrical resistance strain gages with a 3.18-mm (1/8-in.) gage length were used in these tests. Ten three-gage strain rosettes with a delta configurazion (Micromeasurements EA-06-030YB-120) were used for specimen PE-15; the gage langth for the individual strain elements was 0.76 ( $0.030 \mathrm{in.})$. Their locations on the test assembly are shown in Fig. 6. Specimens $\mathrm{PE}-i 7,-18,-19$, and -20 were wore extensively instrumented than the others becsuse gages were wornted on both the inside and the outside surfaces. The gage locations at the central cross section of these elbows are shown in Figs. 7 and 3.

Two types of gages were used at the locations shown in Figs. 7 and 8. Single three-gage rosettes with a 1.57-mo (0.062-in.) gage length. (Micromeasurements EA-06-062RG-120) were designa:ed type B and used for most locations. The second type of gage rosetle, type A (Micromeasurements FA-06-030YB-120) was furnished by the manufacturer in stringers of five closely spaced units, with the rosettes spaced enter to center at $3.15 \mathrm{~mm}$ $(1 / 8 \mathrm{in.}$.) (A stringer is shown in Fig. 9.) Trese stringers can be trimmed so that when two are fitted together, the sfacing between end gages for the two stringers is $3.18 \mathrm{~mm}(1,8 \mathrm{in.})$.

For reference, each type B rosette was designated according to its angular location; the type $A$ rosettes were near the $90^{\circ}$ location. The identification system used for tach cross section is show in Figs. 7 and 8. Type B rosettes were used on the outside at $90^{\circ}$ for specimen $\mathrm{PE}-18$ and on the inside at $90^{\circ}$ for PE-20.

Brittle lacquer and birefringent coatings were also used on some specimens to verify that plastic collapse occurred in the elbows rather than in some other part of the system and to indicate locations and extents of plastic zones. The strain-gage data were used to examine details of behavior for elbows PE-17, $-18,-19$, and -20 , but generally they were used to determine loads at which deviation from linear response occurred and to provide estimates of collapse loads. Quantitative anaiyses were not made with respect to the brittle lacquer and birefringent coatings. 


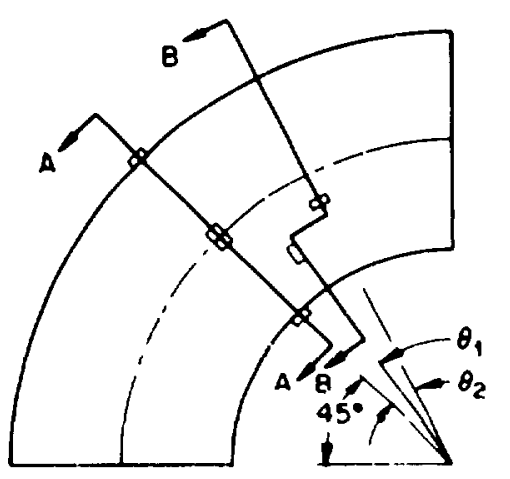

OANL OWG $\gg$ 924R

\section{$\theta_{1}=4^{\circ}$}

$\theta_{2}=9^{\circ}$

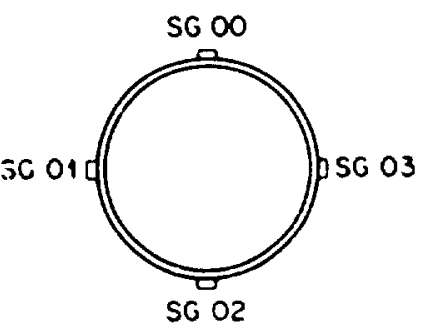

SECTION A-A

TEST PE-1 (FIG 22)

TEST PE-2 (FIG. 23)

TEST PE-8 (FIG 25)

TEST PE-10

TEST PE-11 (FIG 26)

F18. 5. Dlagram of strain-gage locations, PE-1, $-2,-3,-8,-10,-11$.

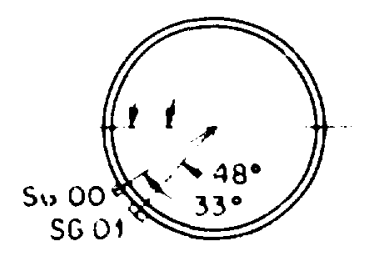

SECTION A-B

TEST PE-3 (FIG 24)

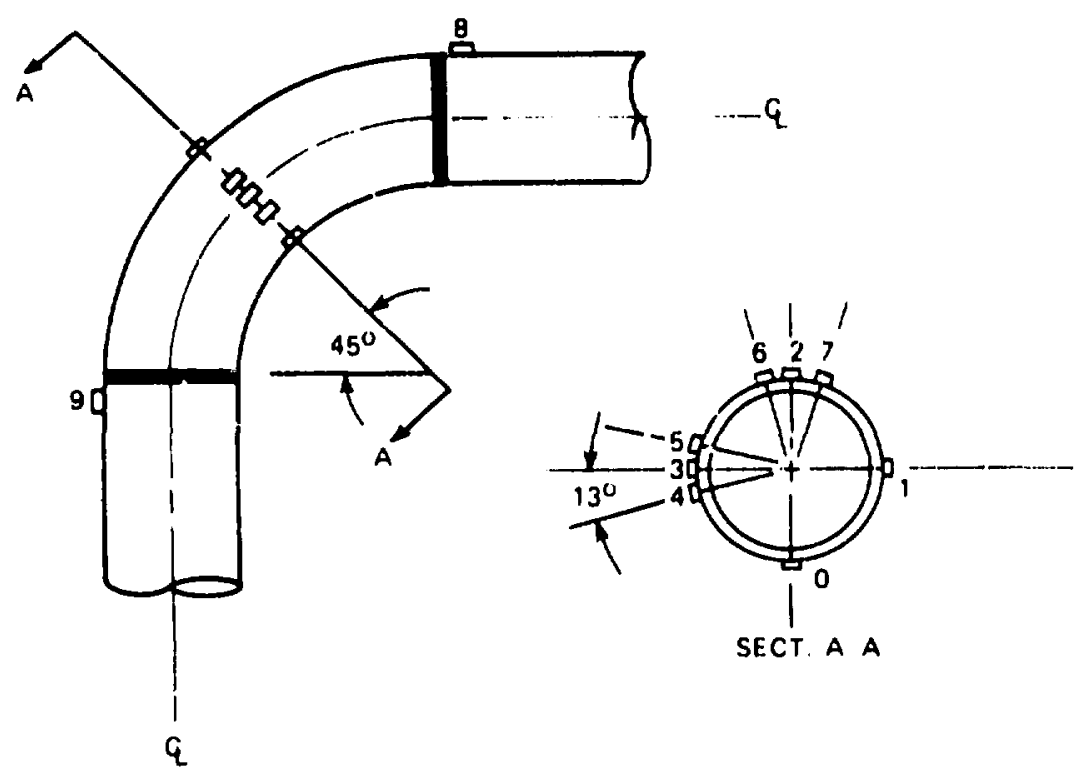

F18. 6. Diagram of stra1n-gage locations, 


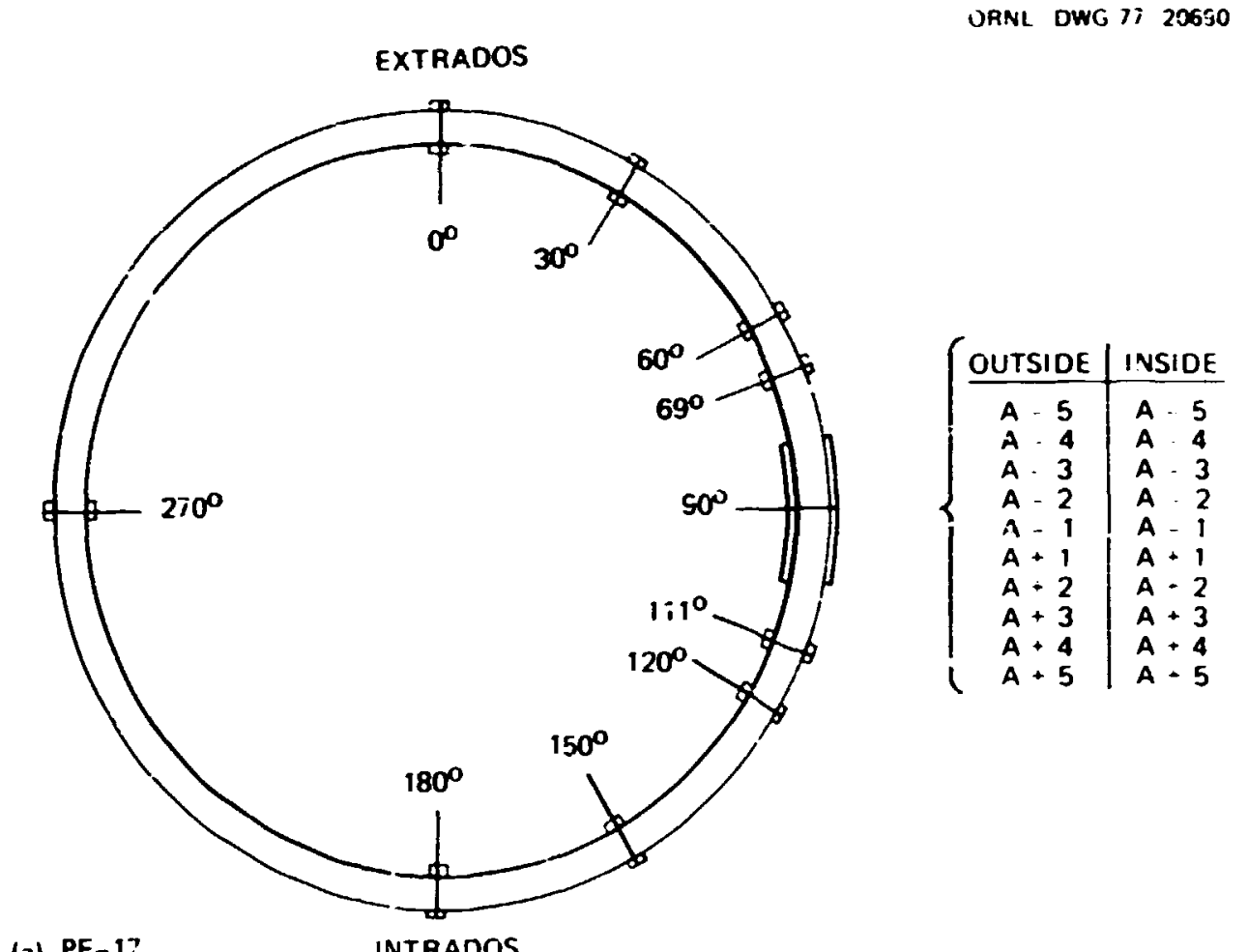

(a) PE-17 INTRADOS

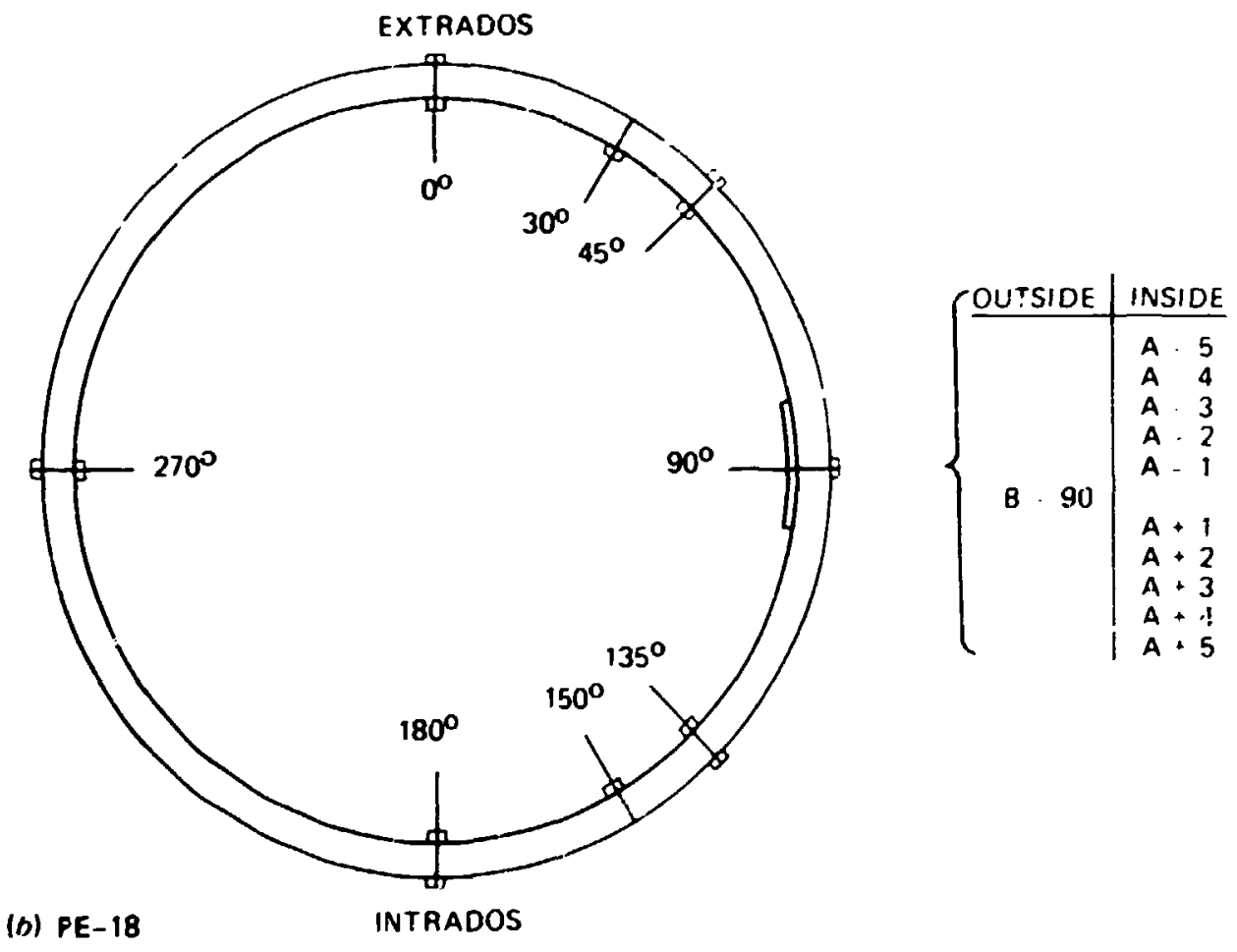

Fig. 7. Strain-gage locations on $45^{\circ}$ cross-sectional planes of $P E-18$ and -19 . 

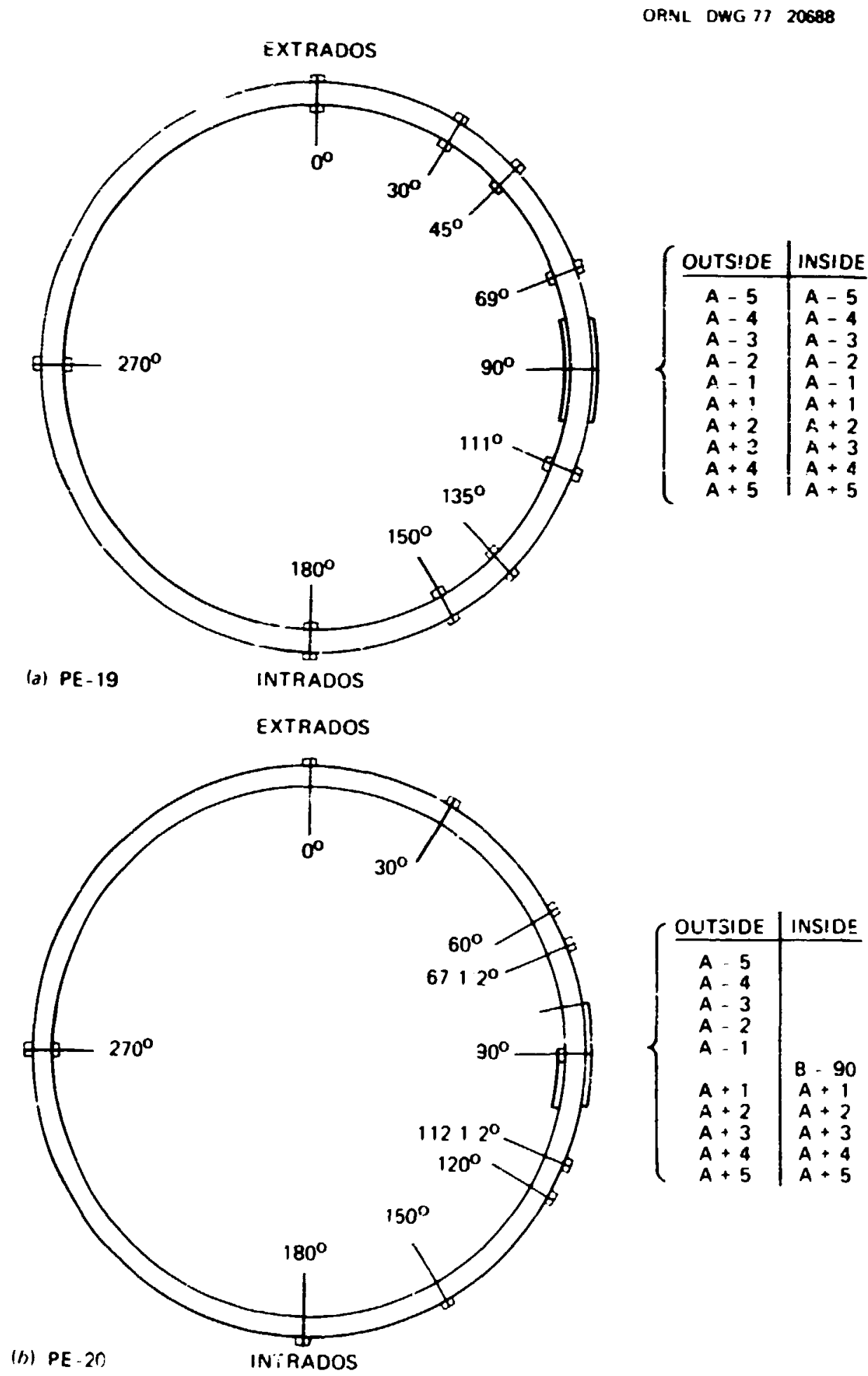

Fig. 8. Strain-gage locations on $45^{\circ}$ cross-sectional planes of $\mathrm{PE}-19$ and -20 . 


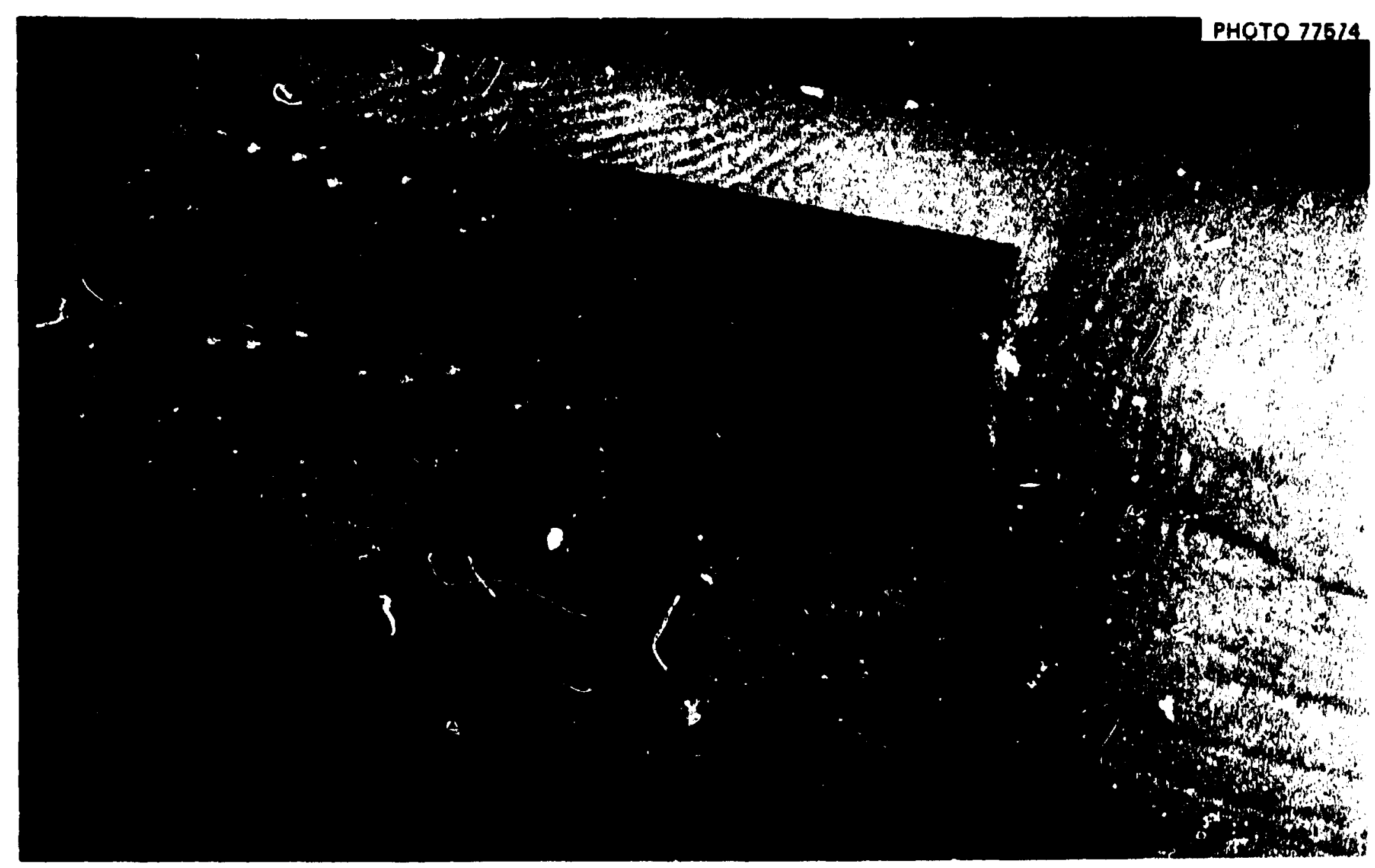

F18. 9. Assembly of five strain-gage rosettes on common foll backing. 
Each test was conducted by slcily applying the force loadings stepwise. The dial indicator readings were tabulated for eaci lcad increment, and the strain-gage data :ere recorded at each step with an automatic strafn-gage scanning and indicating system, Binary Electronics model 225.

\section{EXPERIMENTAL RESULTS}

Load-deflection curies were obtainea for all specimens; representative plots are included for illustration. Curves are shown for specimen PE-1 in F18. 10, PE-2 in Fig. 11, and PE-3 in Fig. 12. These three specimens were long-radius, sched-40 elbows, and each was subjected to one of the three moment loadings employed (see Table 2). The curves show regions of Initial inear (elastic) response and a gradual trangition to predominantly plastic behavior.

In several instances, limitations on maximum loading ram irave? and/or dial indicator travel limited the range of deflections that could be examined. However, in cases where the load-deflection curves extended well into the region of predominantly plastic behavior, there were no observable indications of alterations in response attribitabie either to geometry change effects or to strain nardening. One of the curves for $P E-1$ and one for PE-2 indicate these larger deflection trends.

Figures $1 ?$ and 14 show the load-deflection curves for specimens PE8 (a sched-80 long-radius elbow) and PE-11 (a sched-40 short-radius elbow), respectively. The curves for PE-8 ghow leveifng-off trends with increase in deflection.

The load-deflection curves for specimen PE-13 are showil in Fig. 15. In this case, the assembly was subjected to internal presiure plus force to produce an in-plane moment. Again, these curves show the initial elastic response and the gradual transition to predominantly plastic behavior. However, the slopes in the predominantiy plastic region are much greater than those for the specimens discussed above and show stiffening which results from the addition of internal pressure.

Specimens PE-2, -15 , and -16 were sched-40, long-radius elbows; the first was carbon steel and the others were stainless steel. Loaddefiection curves for specimens $\mathrm{PE}-2$ and -16 are plotted together in 


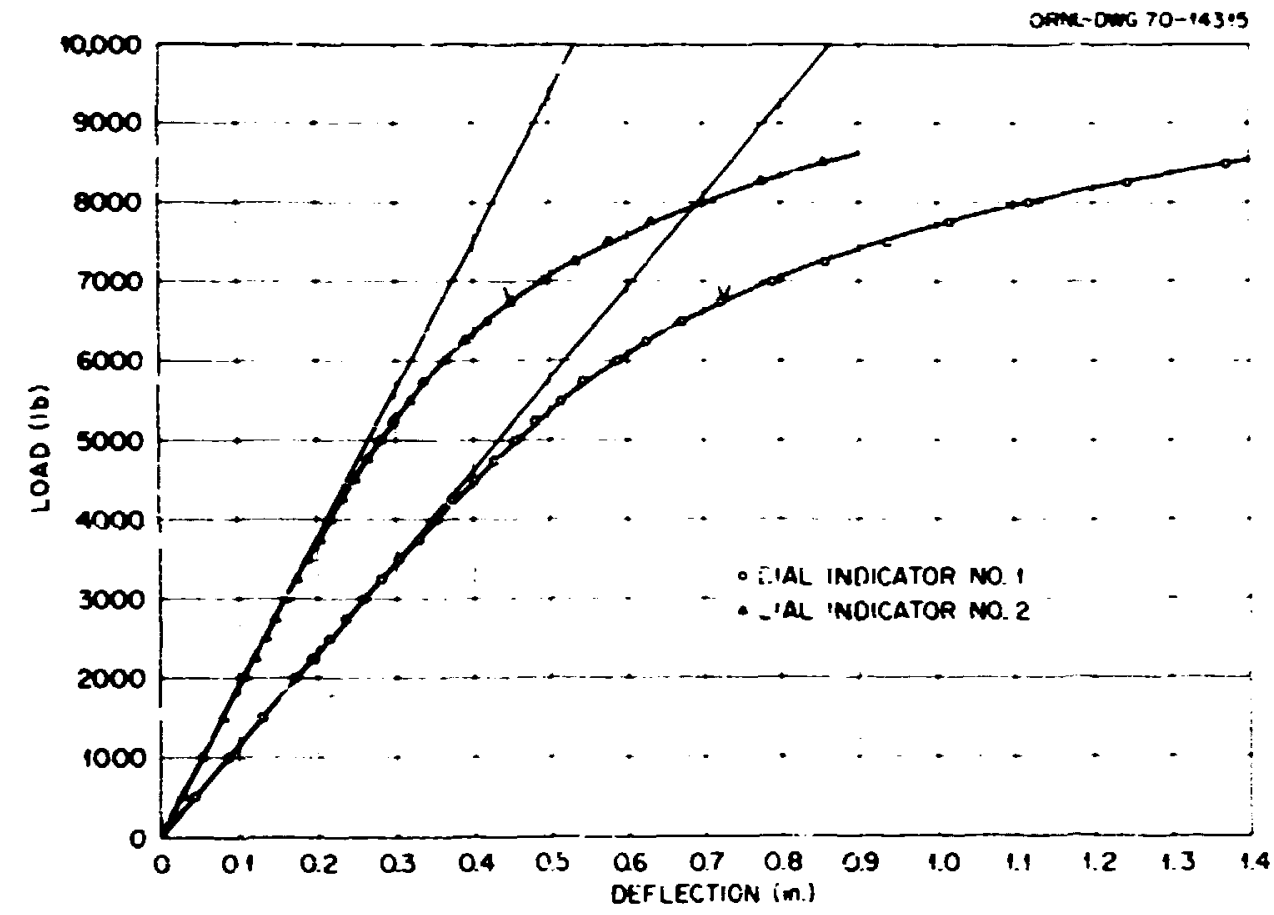

Fig. 10. Load-deflection curves for in-plane bending . specimen PE-1 ( 1 in. $\left.=25.4 \operatorname{mom} ; 11 b_{f}=4.448 \mathrm{~N}\right)$.

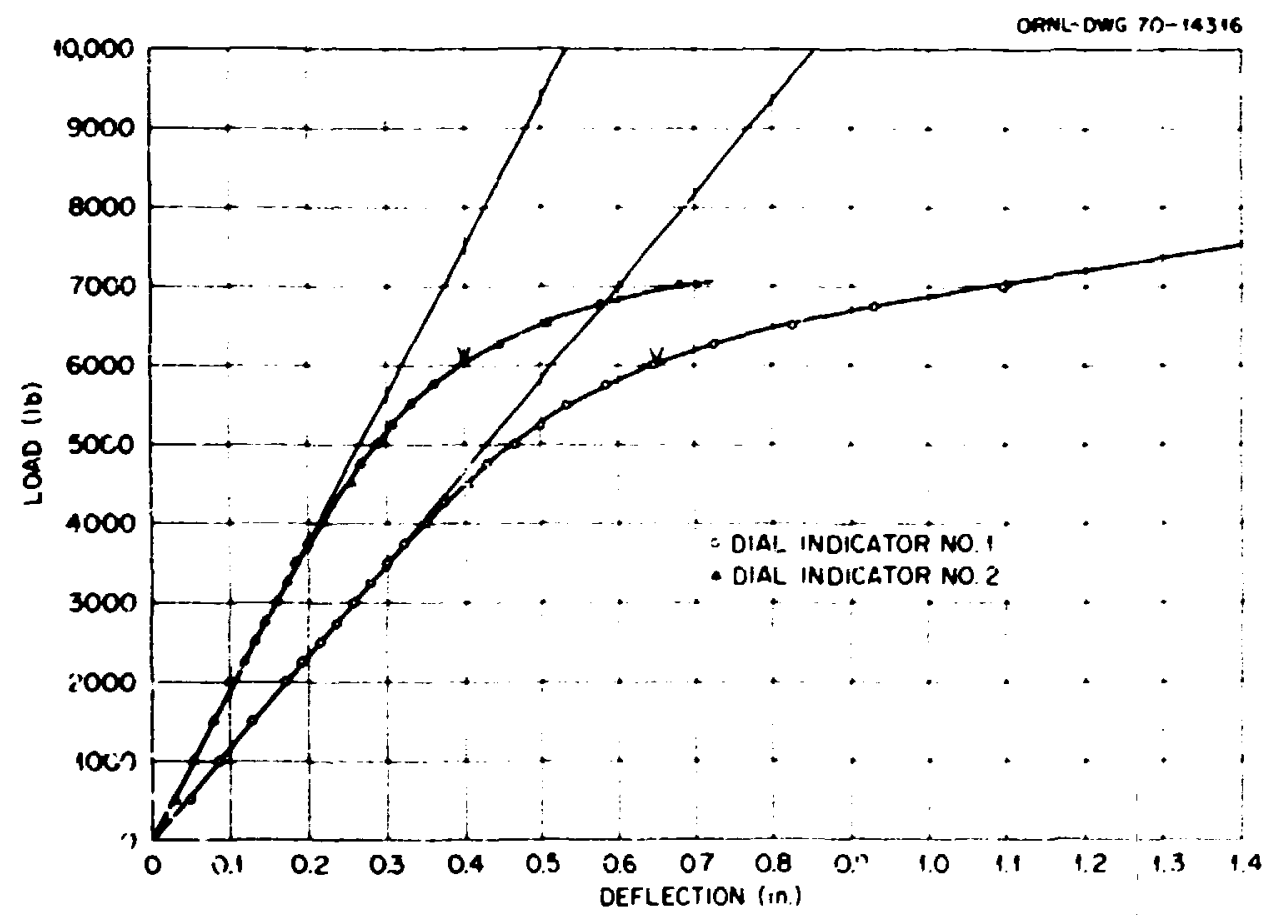

P1g. 11. Lcad-deflection curves for in-plane bending $\left(-M_{z}\right)$ of specisen PE-2 (1 $\left.\ln .=25.4 \mathrm{~m} ; 1 \mathrm{bb}_{\mathrm{f}}=4.448 \mathrm{~N}\right)$. 


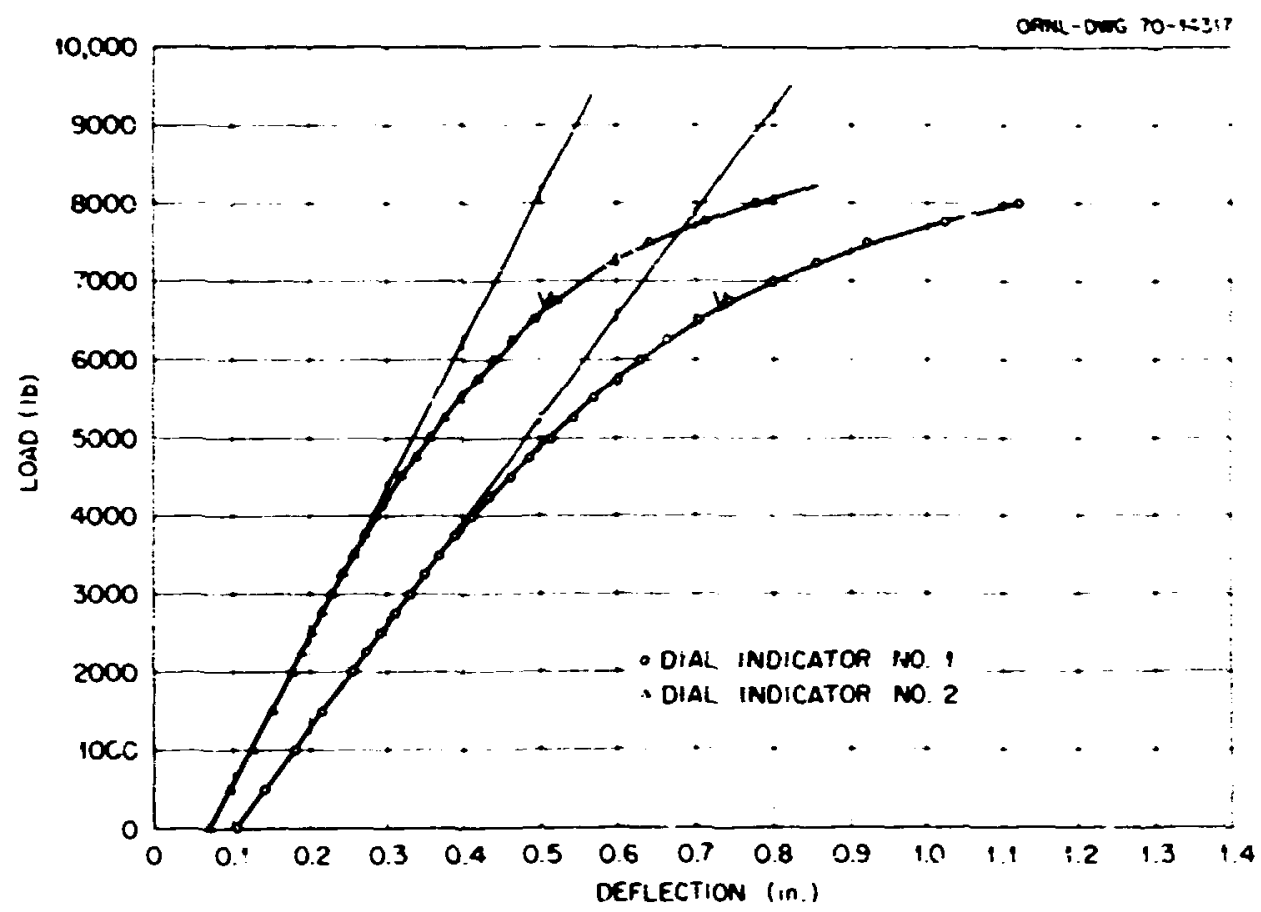

F18. 12. Load-deflection curves for out-of-plane bending $\left(M_{y}\right)$ of specimen PE-3 ( $1 \mathrm{in}$. $=25.4 \mathrm{~mm} ; 1 \mathrm{lb}_{\mathrm{f}}=4.448 \mathrm{~N}$ ).

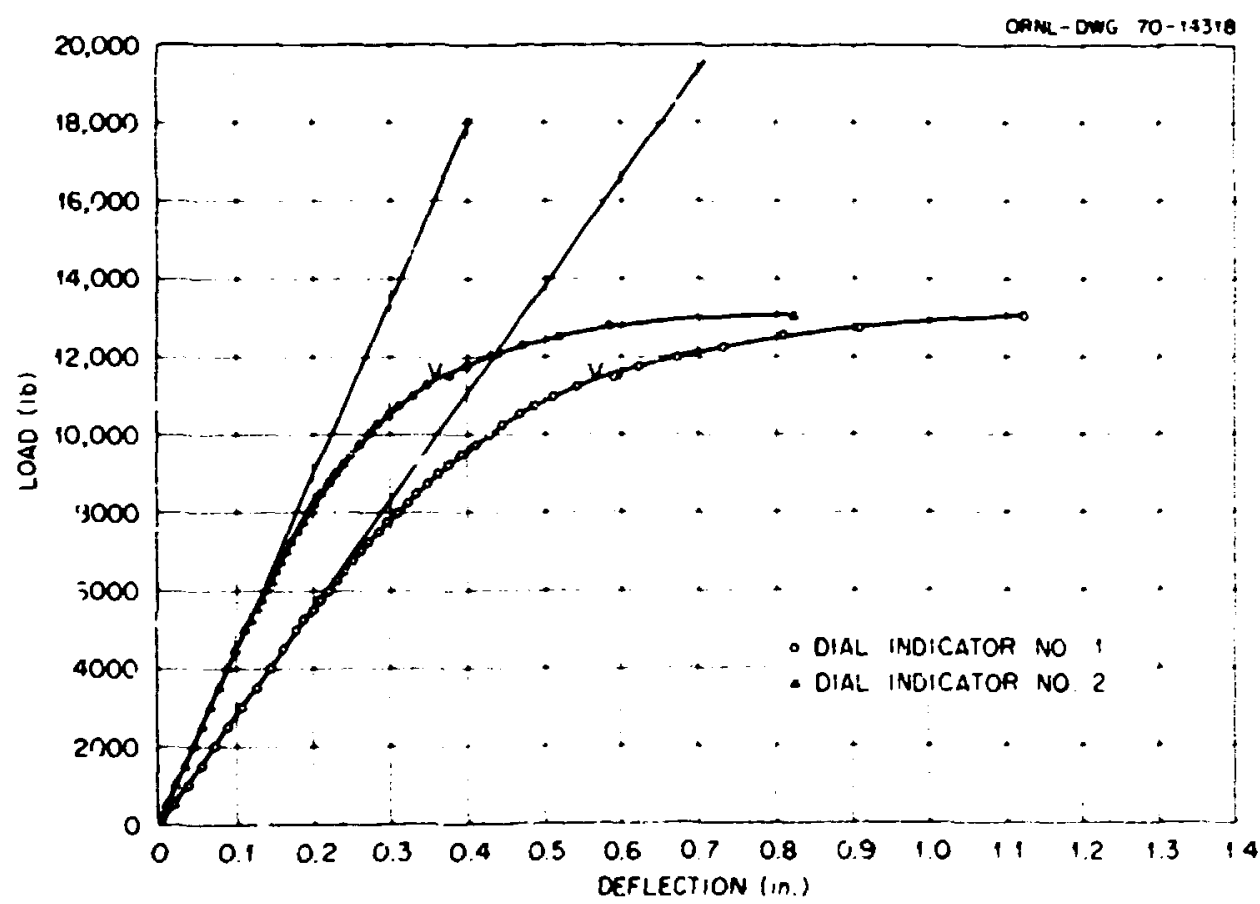

F18. 13. Load-deflection curves tor 1n-plane bending $\left(-M_{2}\right)$ of specimen PE-8 ( $1 \mathrm{in}$. $=25.4 \mathrm{~mm} ; 1 \mathrm{lb}_{\mathrm{f}}=4.448 \mathrm{~N}$ ). 


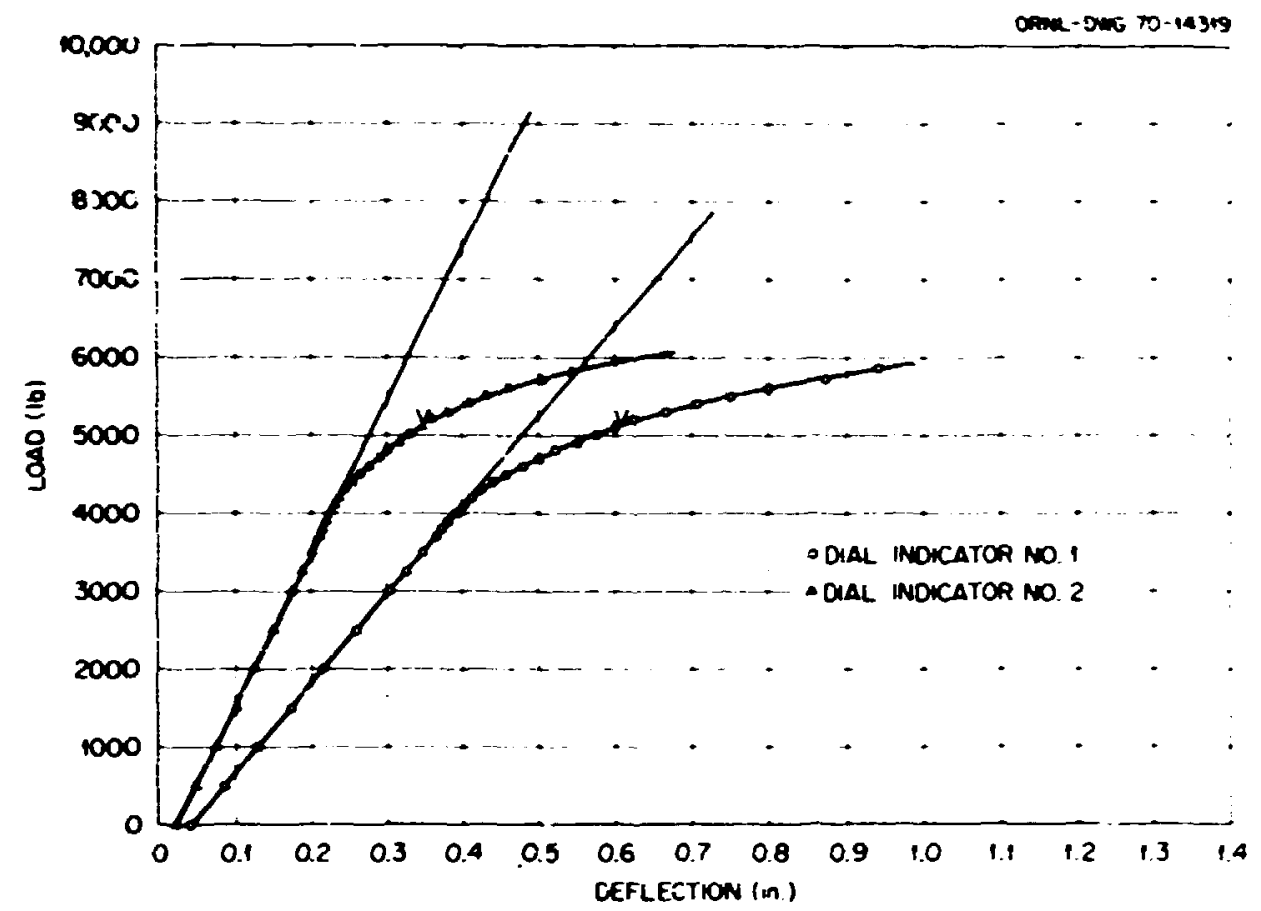

Fig. 14. Load-deflection curves for in-plane bending $\left(-\mathrm{M}_{2}\right)$ of spectien PE-11 ( 1 in. $=25.4 \mathrm{~m} ; 1 \mathrm{lb}_{\mathrm{f}}=4.448 \mathrm{~N}$ ).

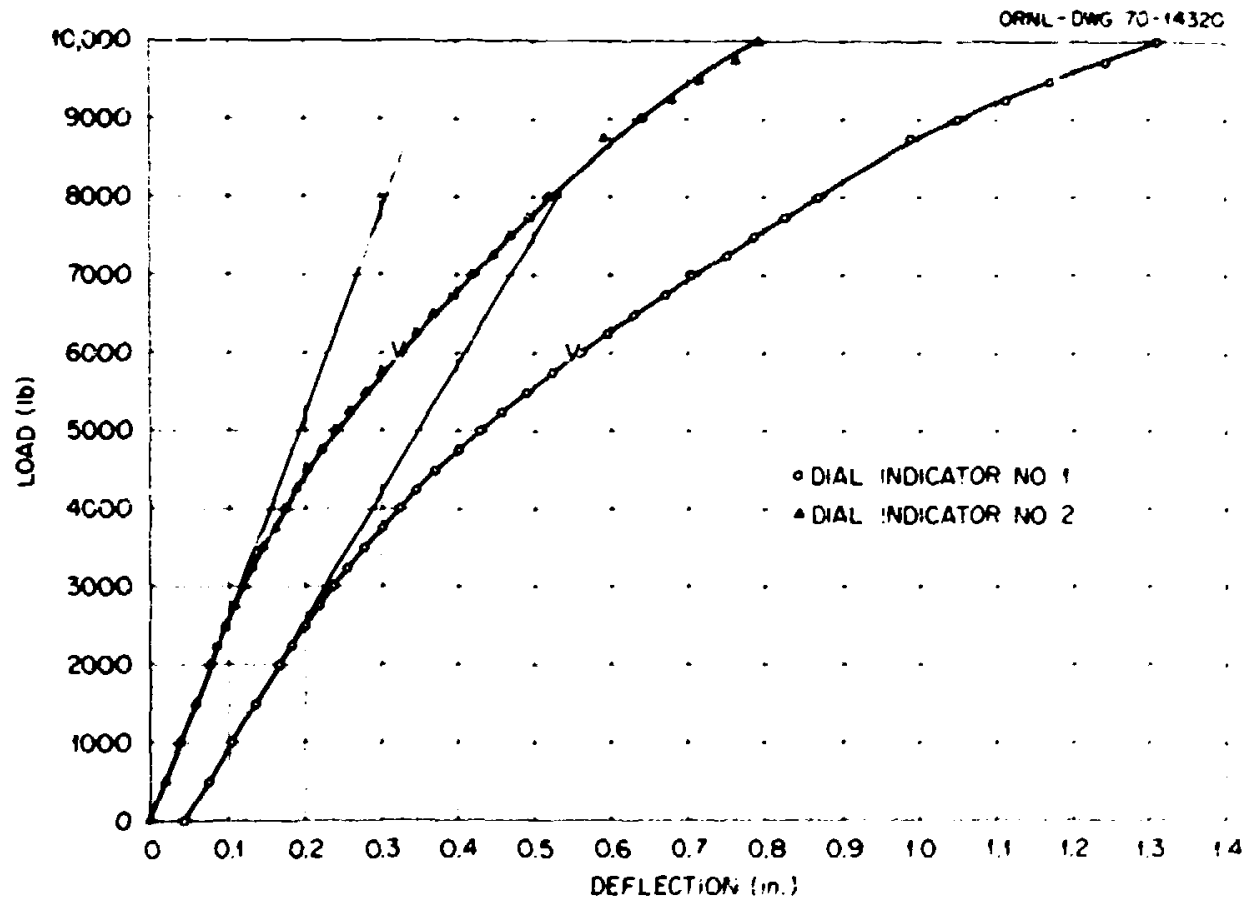

F1g. 15. Load-deflection curves for in-plane bending with internal pressure $\left(\mathrm{M}_{2}+\mathrm{P}\right)$ of specimen PE-13 ( $\left.1 \mathrm{In} .=25.4 \mathrm{~mm} ; 1 \mathrm{lb}_{\mathrm{f}} \approx 4.448 \mathrm{~N}\right)$. 
Fig. 16 to show differences in response for stainless steel and carbon steel specimens. Ta load-deflection curves for PE-15 (shown in Fig. 17) are very similar to those for $P t-16$. The collapse load for the carbon steel specimen is higher, but the transition from initial inear response to predominantly plastic response is more rapid than that for stainless steel.

Special care was given to the testing of $P E-17$ through -20 . The test procedures were established to assure that the load-deflection curves would extend well into the region of predominantly plastic response; and, as noted, strain gages were mounted on both the inside and the outside of the elbows at the central cross section. These gages were for montoring strain distributions as functions of load and for determining onset of nonlinear response from the Individual load-strain histories. The load-deflection curves for each of the four specimens are given in Figs. 18 through 21.

The load-deflection curves of Figs. 18 thruugh 21 show leveling of at the larger displacements, with the leveling-off treñ being least pronounced for the sched-40 stainless steel elbow, PE-17. In Fig. 20, upper and lower load points are shown on the load-deflection plots for $P E-19$. The lower points were obtained for each displacement increment in the plastic range by holding the deflection fixed until tie corresponding load decreased and stabilized.

Load-strain curves for specimens PE-1, -2, $-3,-8,-11$, and -15 are shown in Figs. 22 through 27. For the most part, the data selected were those for which the forces at $0.2 \%$ offset strain could be determined. The strain-gage numbers correspond to those in Figs. 5 and 6 . The characteristics of these curves are similar to those of the corresponding load-deflection curves, with a small linear response portion for the stainless steel specimen. For the in-plane bending cases, the gages were located in planes in which the major and minor axes of ovaiity for the deformed cross section were expected to lie. In the case of outof-plane bending, Fig. 24, the gages were mounted on the tension side of the elbow, again at locatinns near the position of the major axis of expected ovality. These gages were oriented as closely as possible with the directions of principal strains, as indicated by the brittle lacquer 


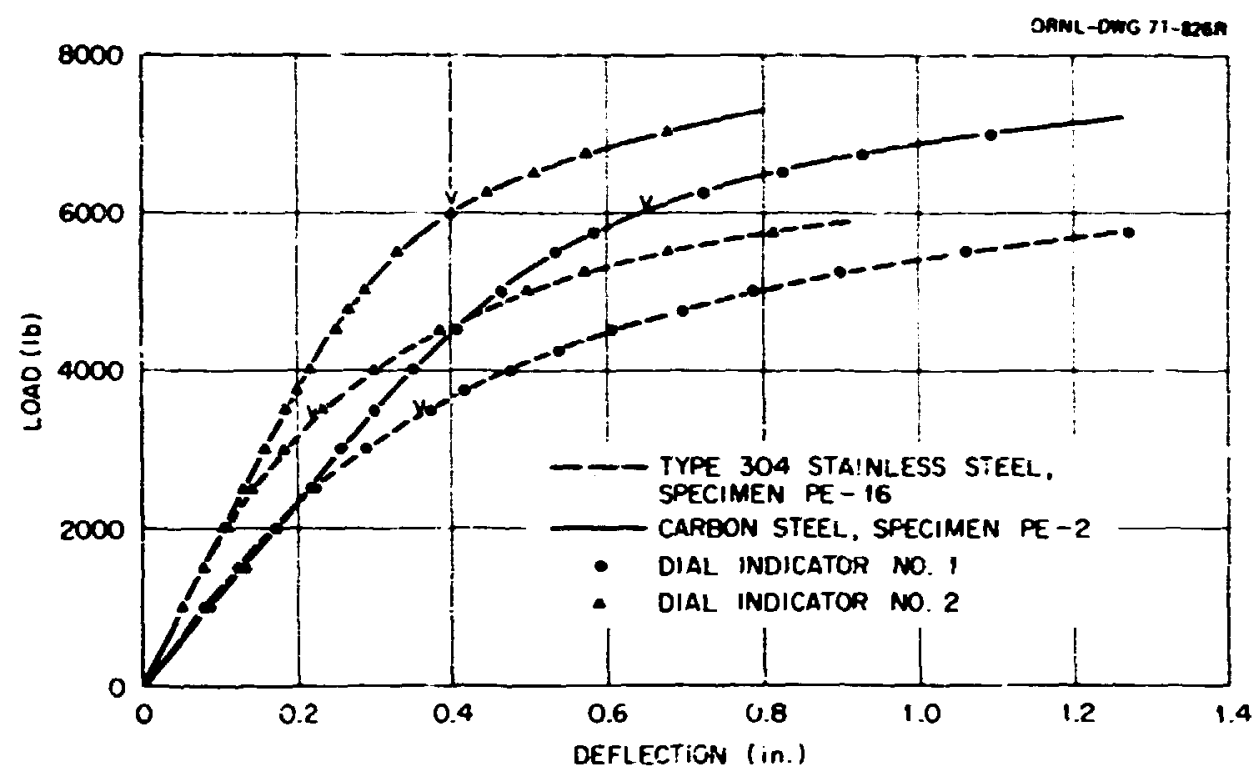

P1g. 16. Load-detiection curves for in-plane bending $\left(H_{2}\right)$ of spectmens $\mathrm{PE}-2$ and $\mathrm{PE}-16\left(1 \mathrm{in}\right.$. $\left.=25.4 \mathrm{~mm} ; 1 \mathrm{lb}_{\mathrm{f}}=4.4 .8 \mathrm{~N}\right)$.

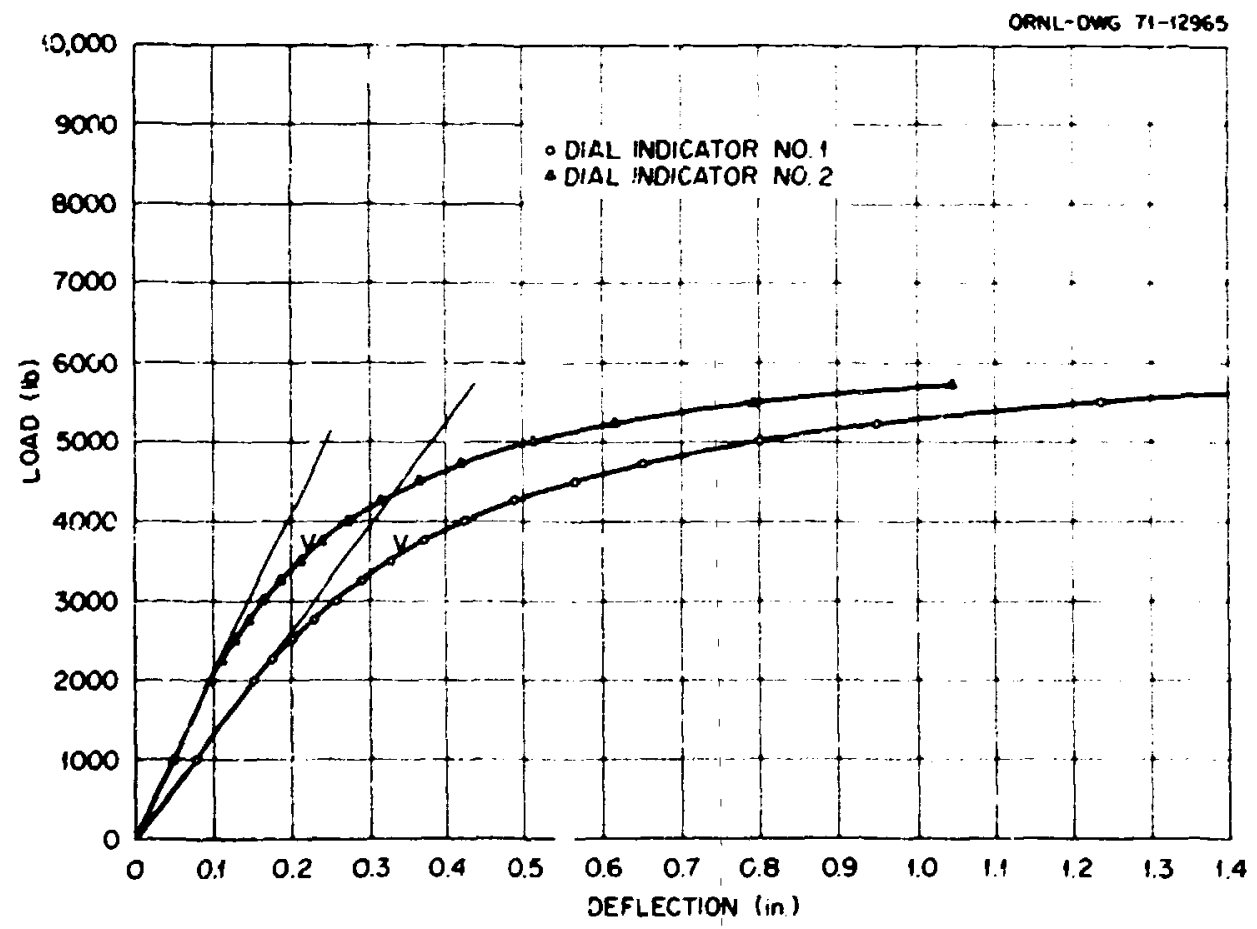

F1g. 17. Lead-deflection curves for In-plane bending $\left(H_{z}\right)$ of specimen PE-15 (1 1n. $\left.=25.4 \mathrm{dm} ; 1 \mathrm{lh}_{\mathrm{f}}=4.448 \mathrm{~N}\right)$. 


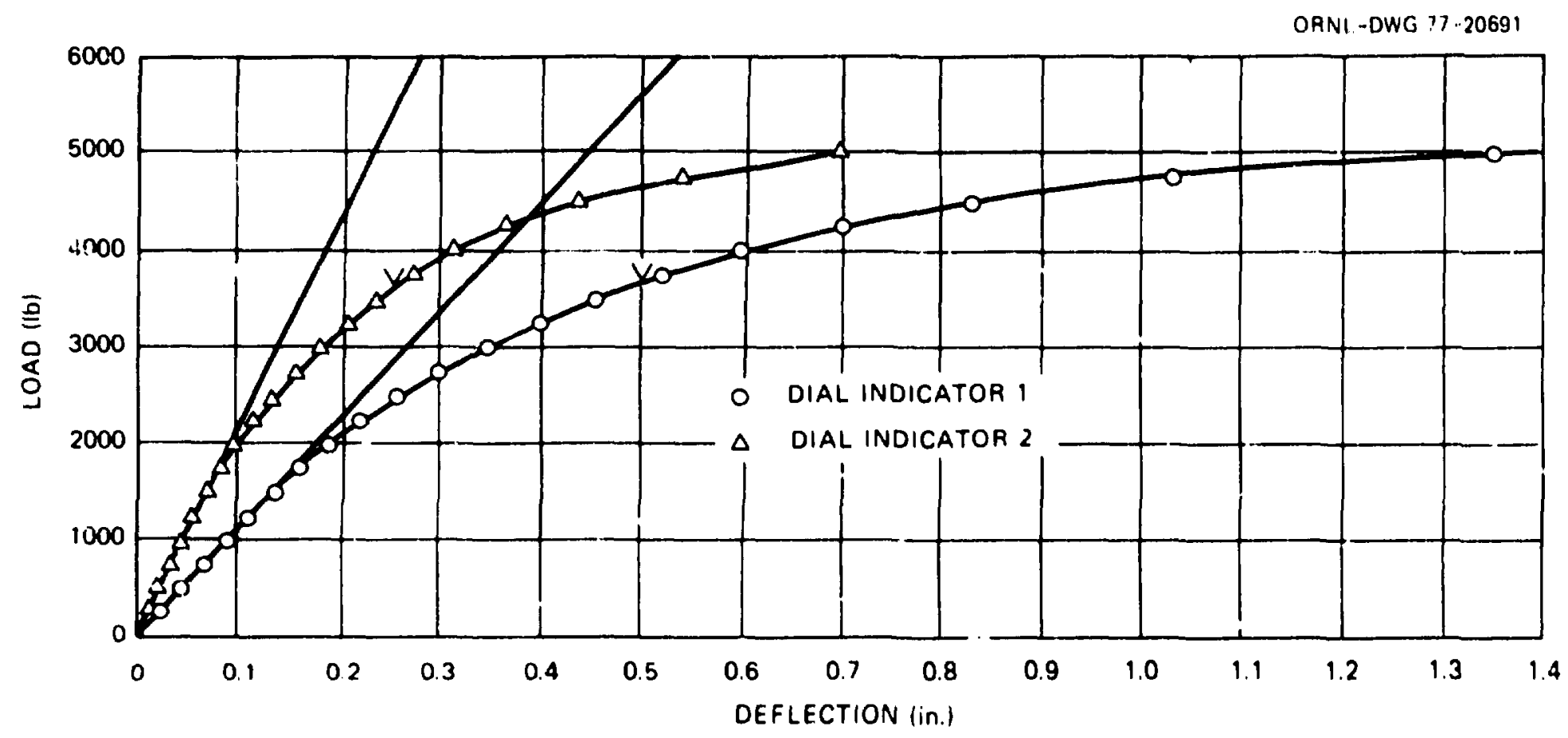

Fi3. 18. Load-deflection curves for In-plane bending $\left(H_{2}\right)$ of specimea PE-17 ( $1 \mathrm{in}$. $\left.=25.4 \mathrm{~mm} ; 1 \mathrm{lb}_{\mathrm{f}}=4.448 \mathrm{~N}\right)$. 


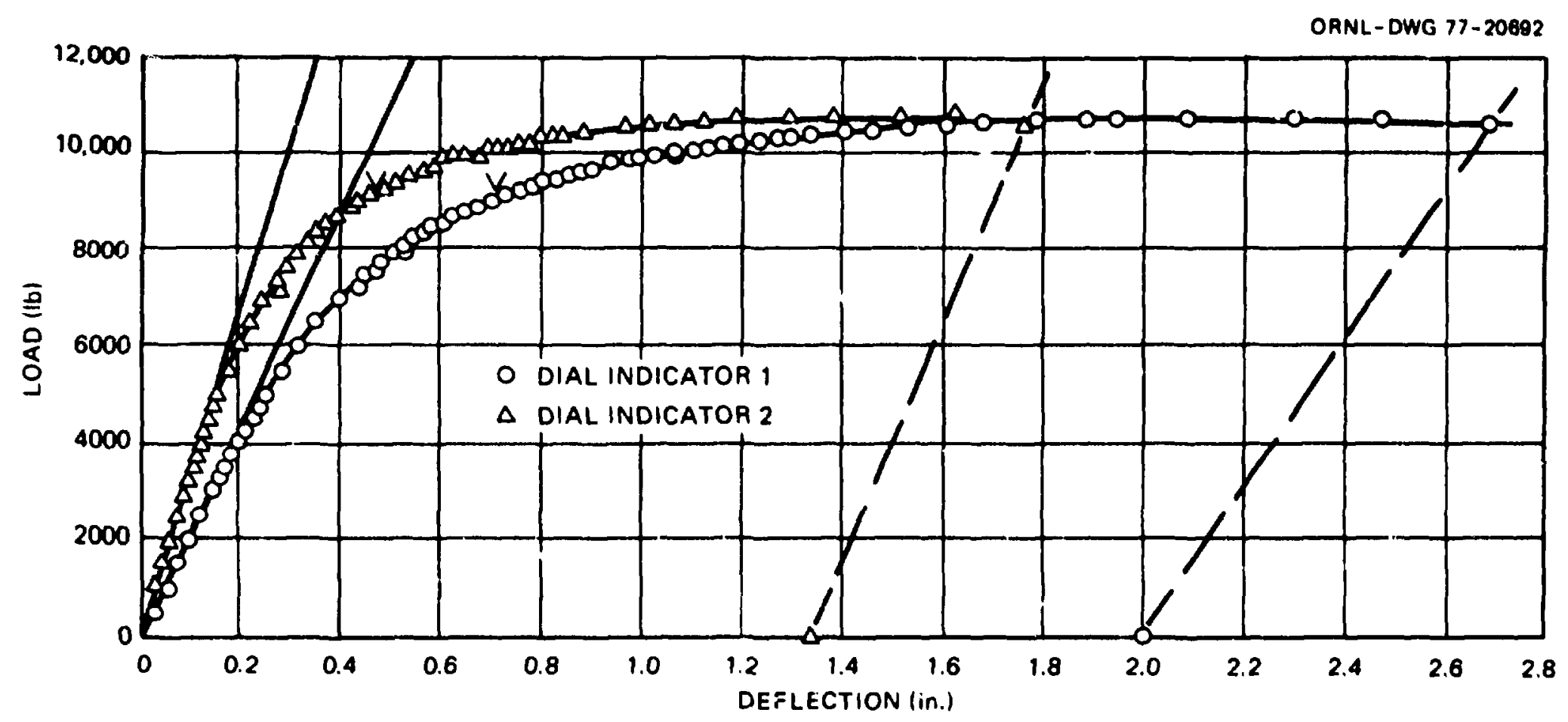

F1子. 19. Load-deflection curves for in-plane bending $\left(-M_{z}\right)$ of specimen PE-18 ( $1 \mathrm{ll}$. $\left.=25.4 \mathrm{~m} ; 11 \mathrm{~b}_{\mathrm{f}}-4.448 \mathrm{~N}\right)$. 
ORNI. DWG $\% \cdot 20693$

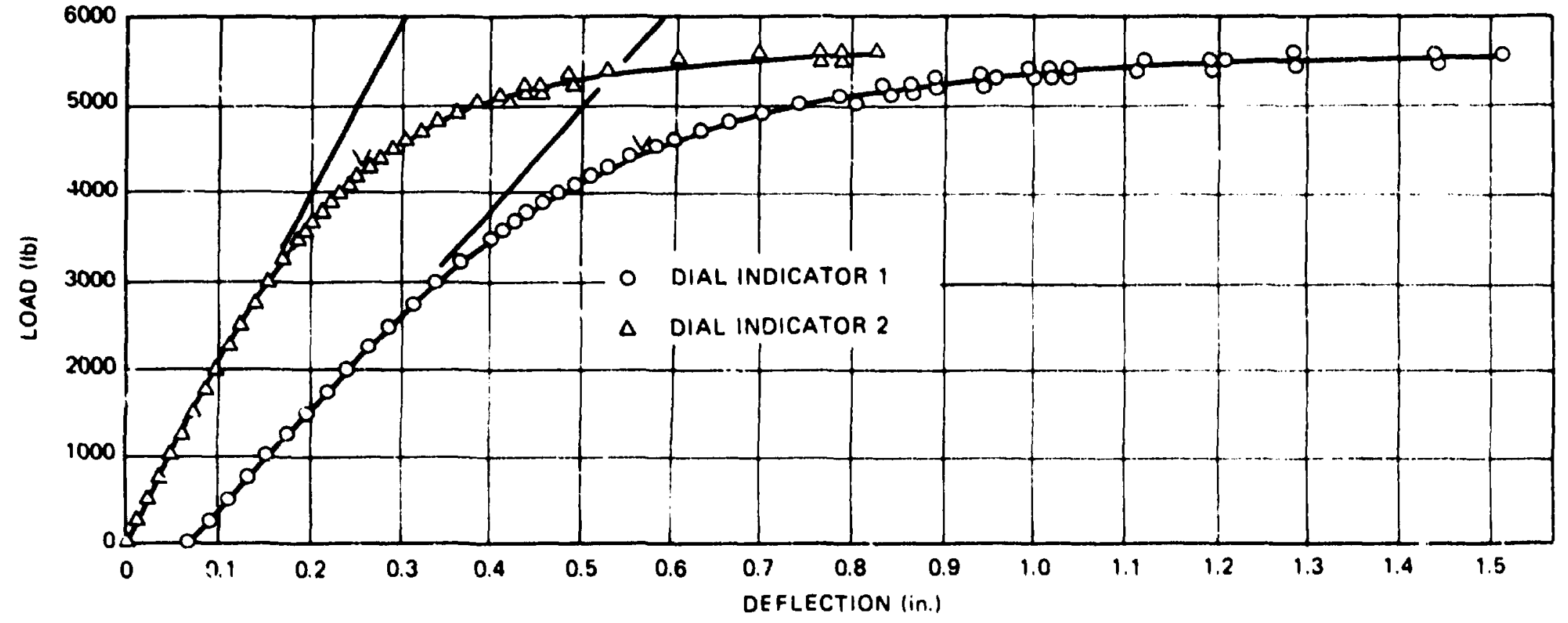

F18. 20. Load-deflection curves for in-plane bending $\left(H_{2}\right)$ of specimen PE-19 ( $1 \mathrm{in}$. $=25.4 \mathrm{mau} ; 11 \mathrm{~b}_{f}=4.448 \mathrm{~N}$ ). 


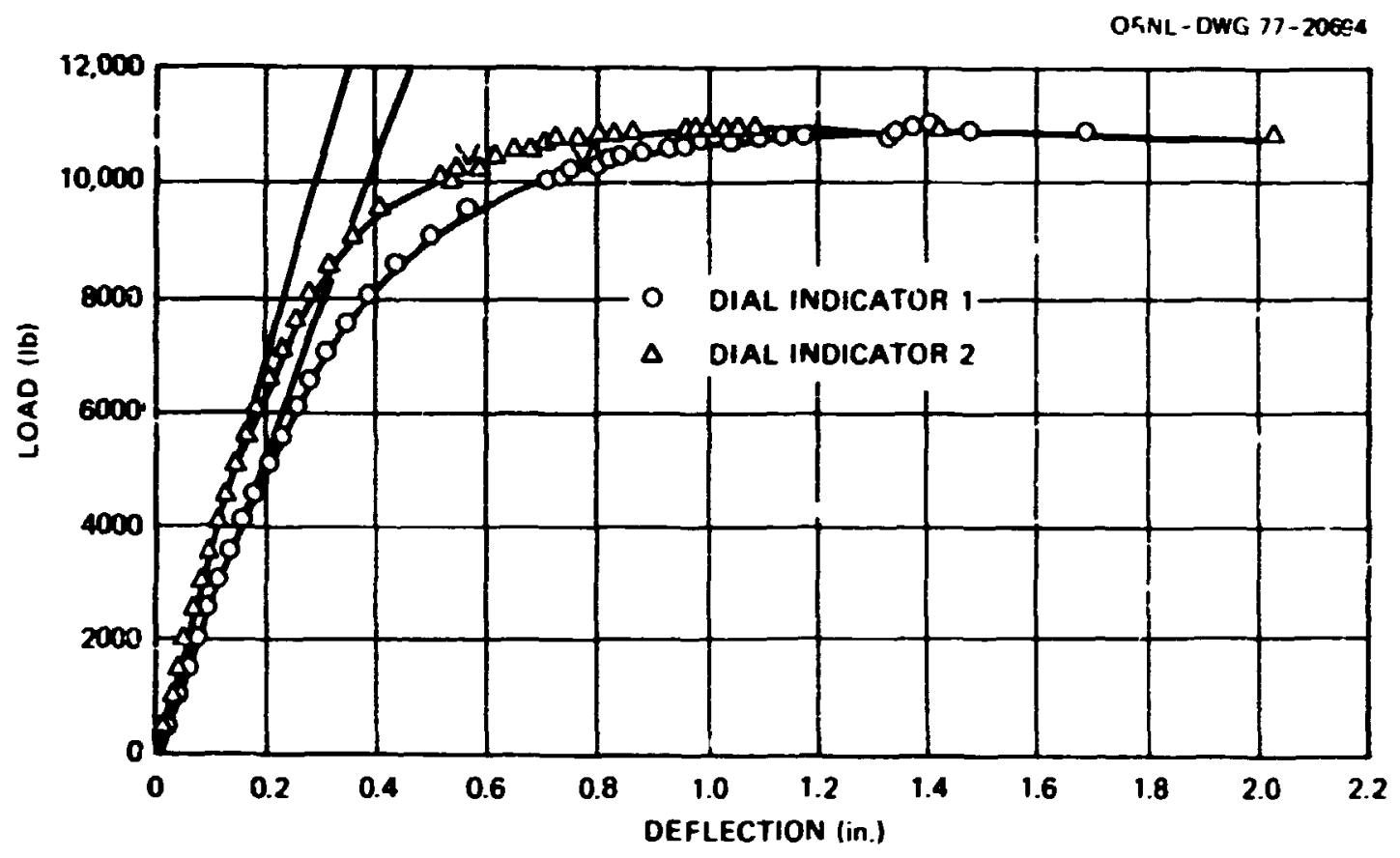

F1g. i1. Load-deflection clrves for in-plane bending $\left(-H_{2}\right)$ of specimen PE-20 ( 1 in. $=25.4 \mathrm{mog} 1 \mathrm{lb} f=4.448 \mathrm{~N})$.

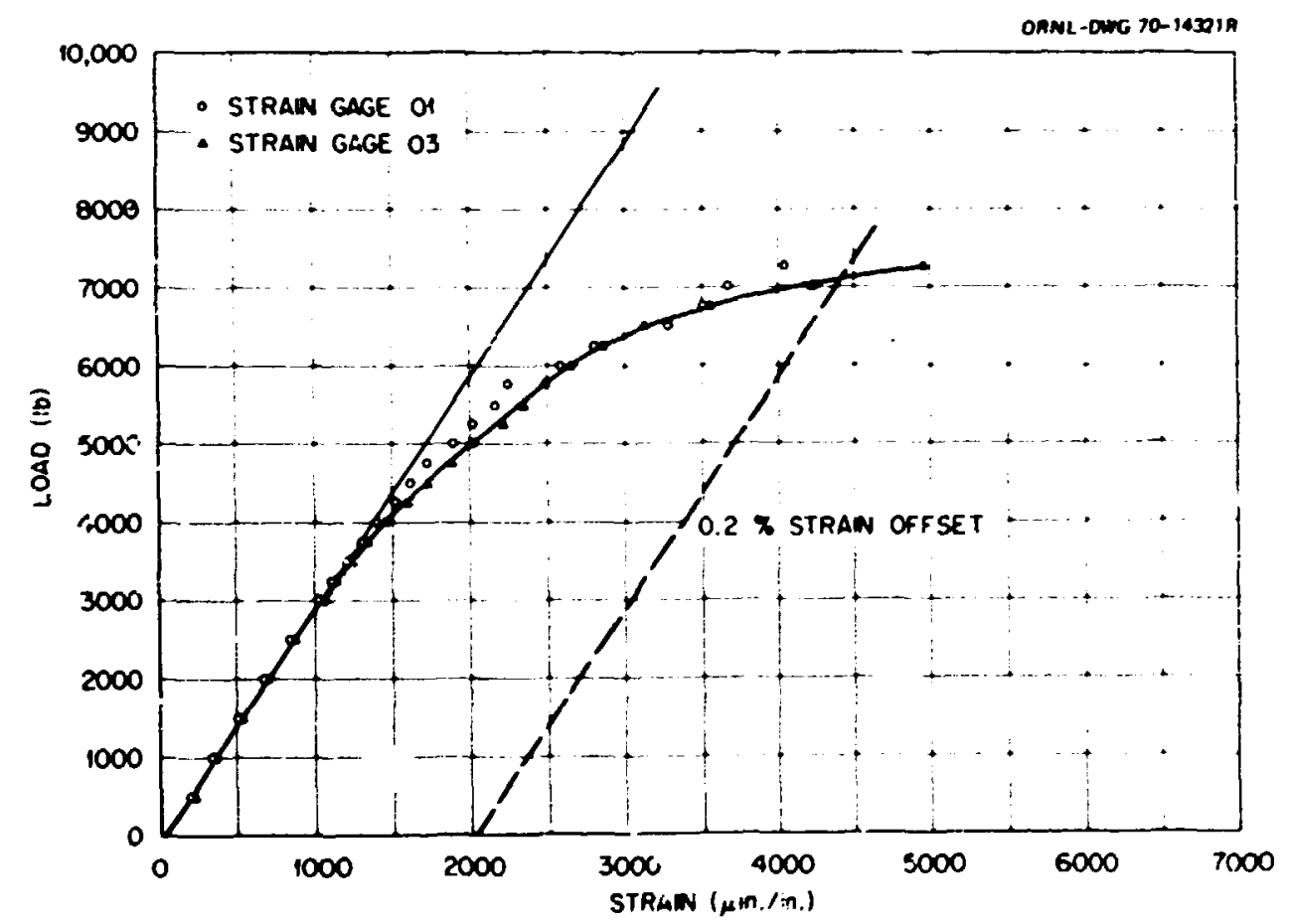

P1g. 22. Load-strain data for in-plane bending $\left(+M_{2}\right)$ of specimen $P E-1\left(1 \quad 1 b_{f}=4.448 \mathrm{~N}\right)$. 


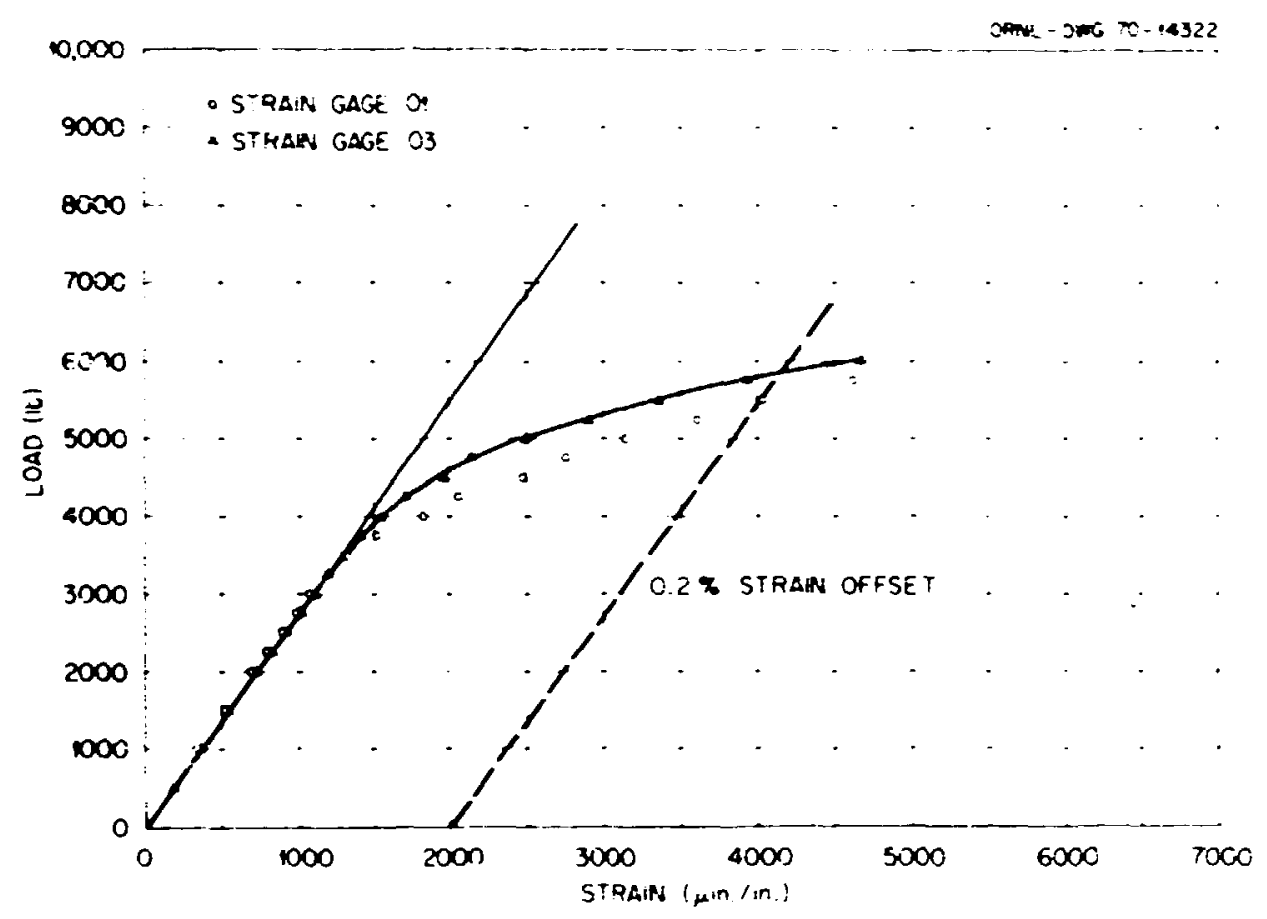

Fig. 23. Load-strain data for in-plane bending $\left(-M_{2}\right)$ of specimen $P E-2\left(11 b_{f}=4.448 \mathrm{~N}\right)$.

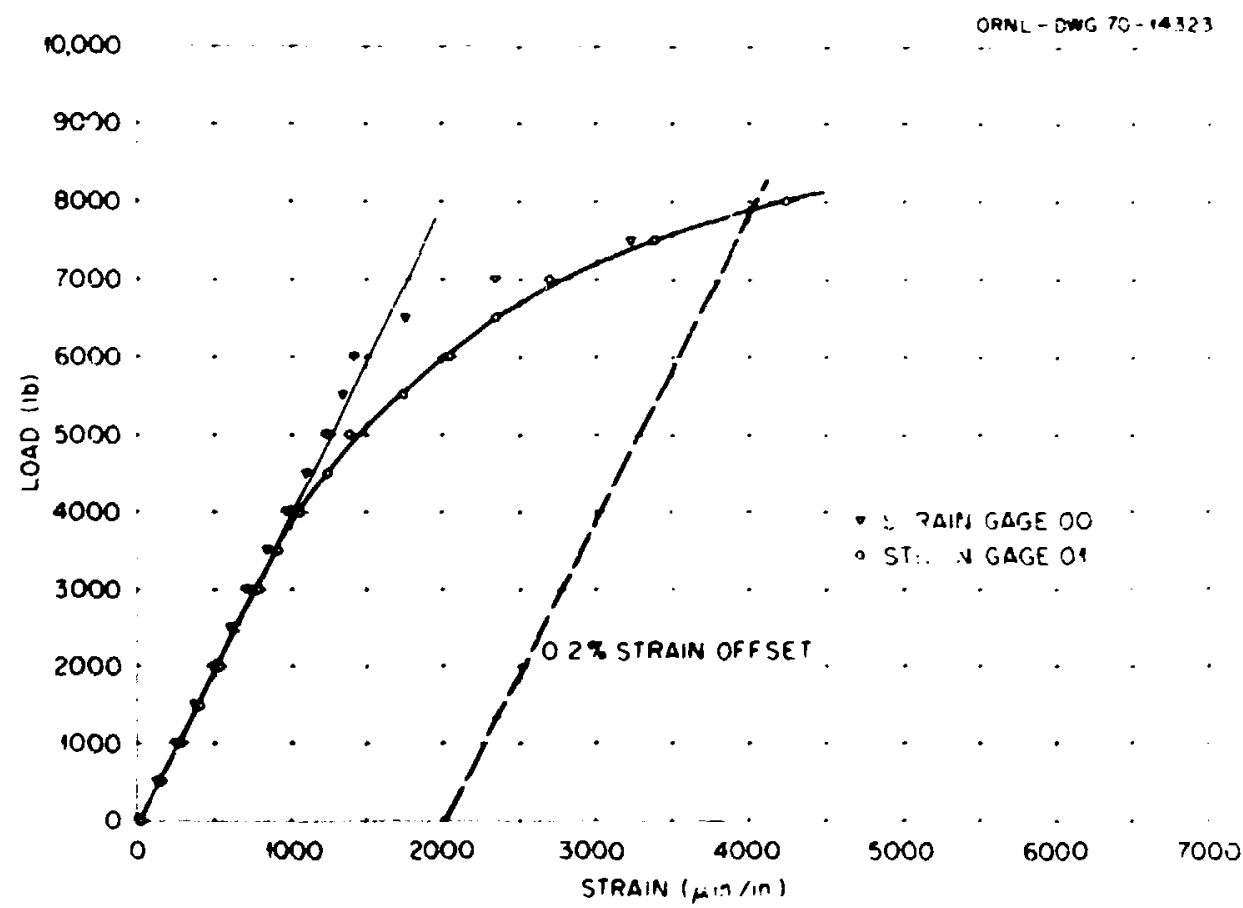

Fig. 24. Load-strain data for out-of-plane bending $\left(M_{y}\right)$ of spectmen $\mathrm{PE}-3\left(1 \mathrm{l \textrm {b } _ { \mathrm { f } }}=4.448 \mathrm{~N}\right)$. 


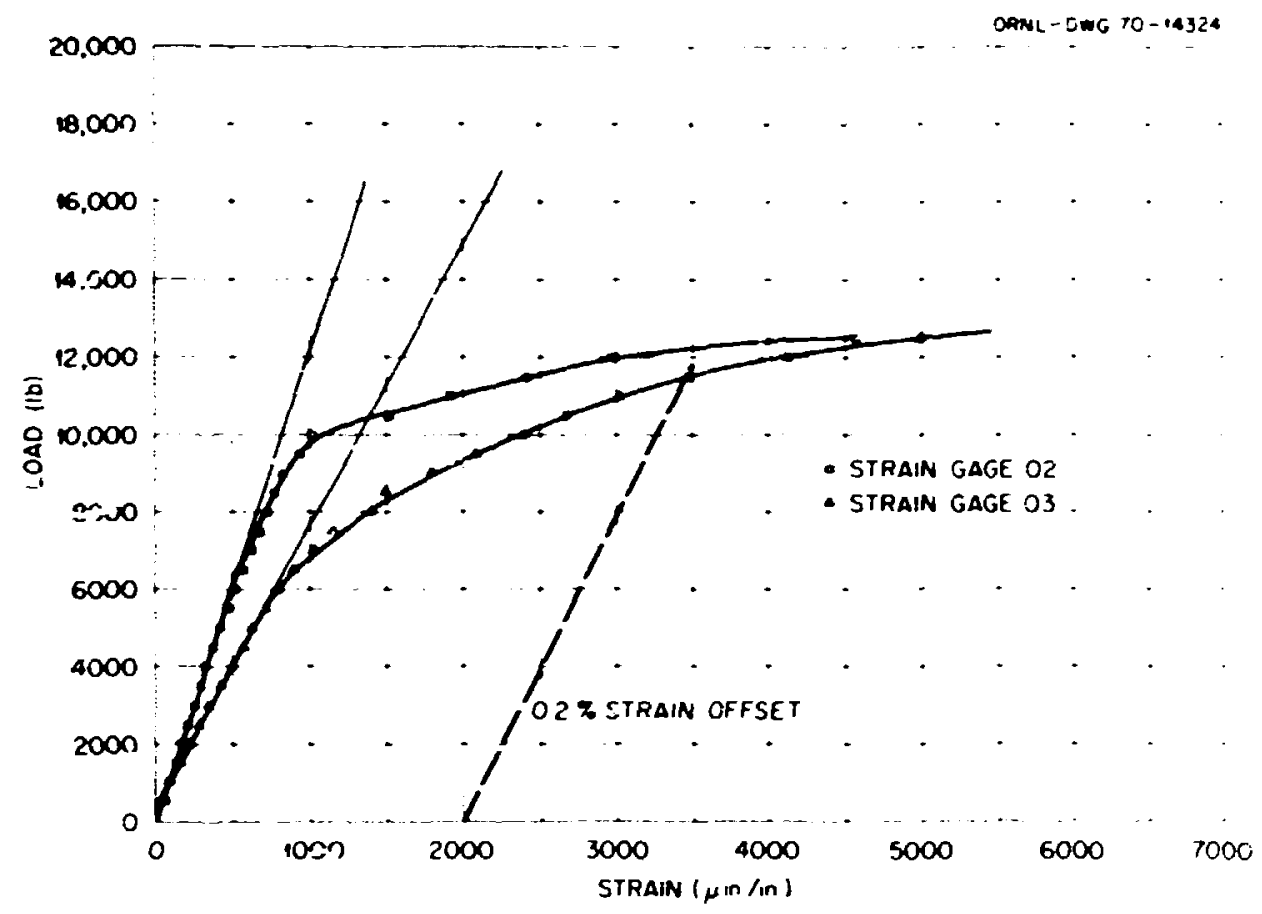

Fig. 25. Load-strain data for in-plane bending $\left(-M_{2}\right)$ of specimen $P E-8\left(11 b_{f}=4.448 \mathrm{~N}\right)$.

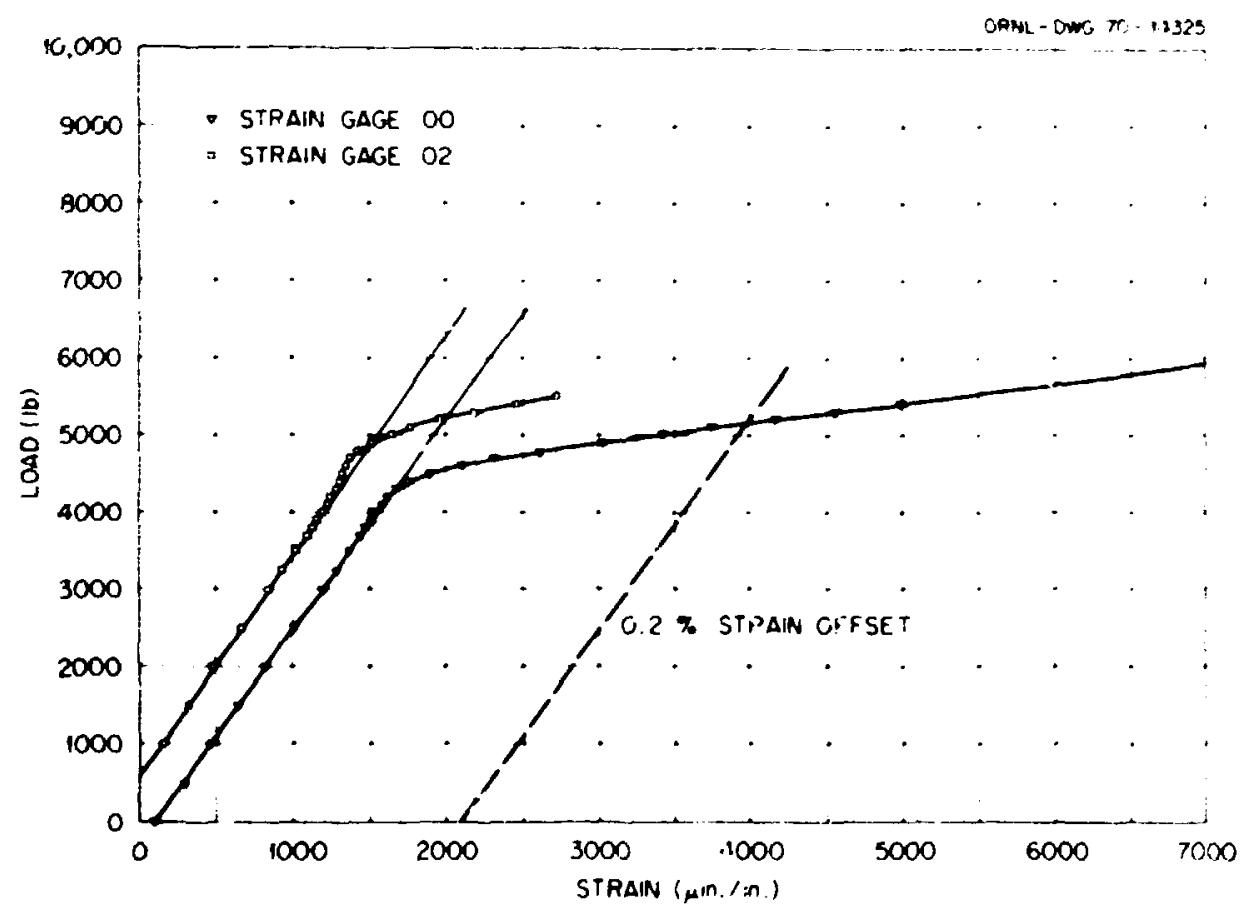

Fig. 26. Load-strain data for in-plane bending $\left(\mathrm{M}_{2}\right)$ of specimen $P E-11\left(11 b_{f}=4.448 \mathrm{~N}\right)$. 


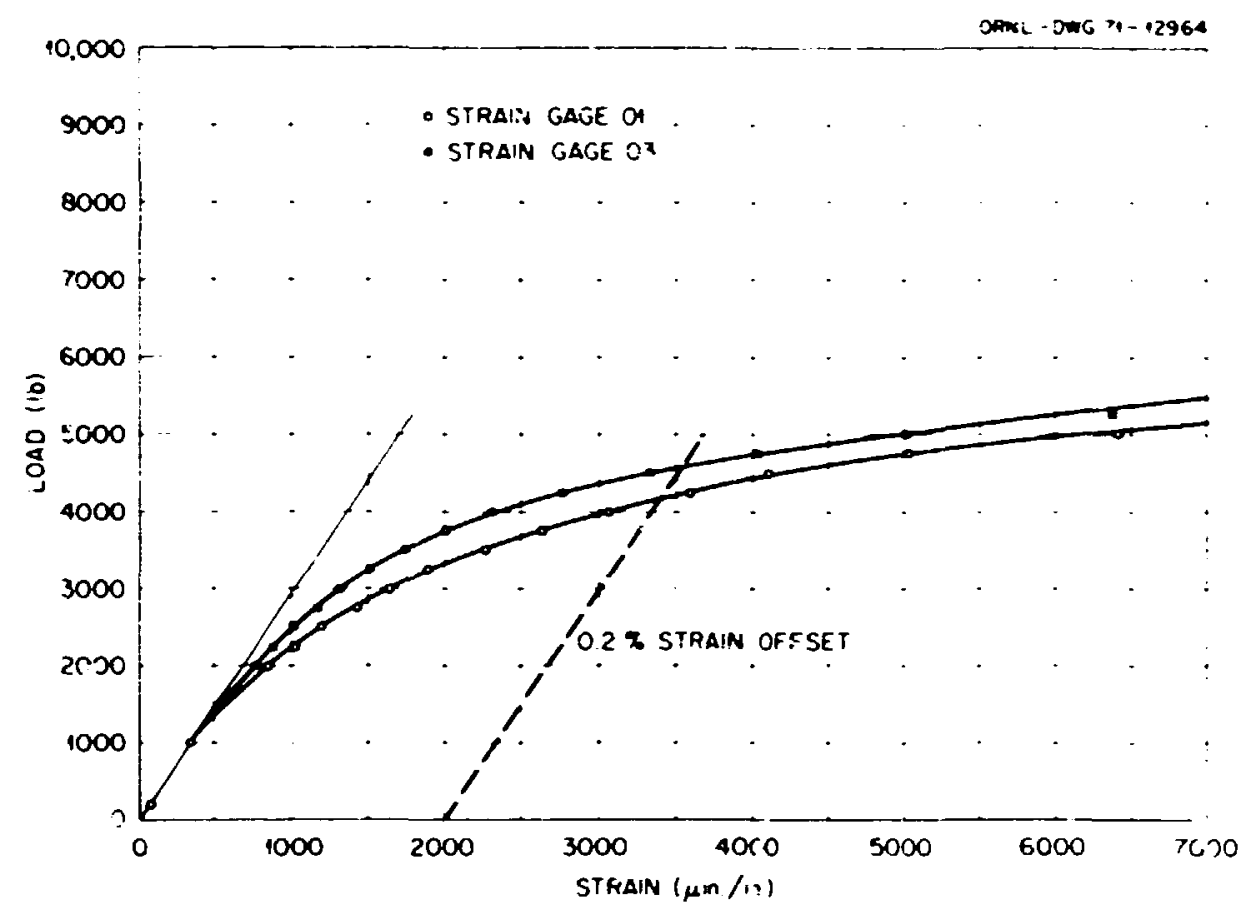

Fig. 27. Load-strain data for in-plane bending $\left(-M_{z}\right)$ of specimen $P E-15\left(11 b_{f}=4.448 \mathrm{~N}\right)$.

tests. However, birefringent coating results indicated a significant difference between the location of maximum gtrain and the locations of the gages.

In the case of a negative in-plane moment $\left(-M_{z}\right)$, which tends to cause the bend radius of the elbow to decrease, the load-strain curves for carbon steel elbows show a relatively rapid transition from elastic to predominantly plastic behavior. For the curves shown in Fig. 26 , the onset of nonlinear behavior, as indicated by strain gage 00 on the convex side (extrados) of the elbow, was accompanied by a tendency for an inftial reduction in strain increase as a function of load on the concave side (intrados) of the elbow, as indicated by strain gage 02 .

The load response of specimen PE-15 was also charted by plotting the angle of rotation, $\theta$, of the plane of the loaded end of the elbow (or, alternately, the rotation of the loaded extension) as a function of load. Values of $\theta$ were calculated from the displacements measured at the end of the elbow and the deflections obtained from the two dial indicators 
positioned as showa in Fig. 2. Load-v's-angle curves are shown in Fig. 28, where $\theta_{1}$ and $\theta_{2}$ weze obtained from indicators DI 1 and DI 2 , respectively.

Circumferential strain at the midplane $\left(45^{\circ}\right.$ plane) is plotted as a function of angular position in Figs. 29 and 30 for PE-18 and -19 , respectively. The circumferential strain is the maximum principal strafin, and the angular locations are as shown in Figs. 7 and 8 . The :urves shown are for constant loads as indicated on the curves for the insid: surfaces. The load ranged from 15.57 to $44.26 \mathrm{kN}$ ( 3500 to $9950 \mathrm{lb}$ ) for PE-18, and the range was from 6.67 to $22.24 \mathrm{kN}$ (1500 to $5000 \mathrm{lb})$ for PE-19. These plots show that the maximum strain occurs on the inside surfaces near the $\ni 0^{\circ}$ location.

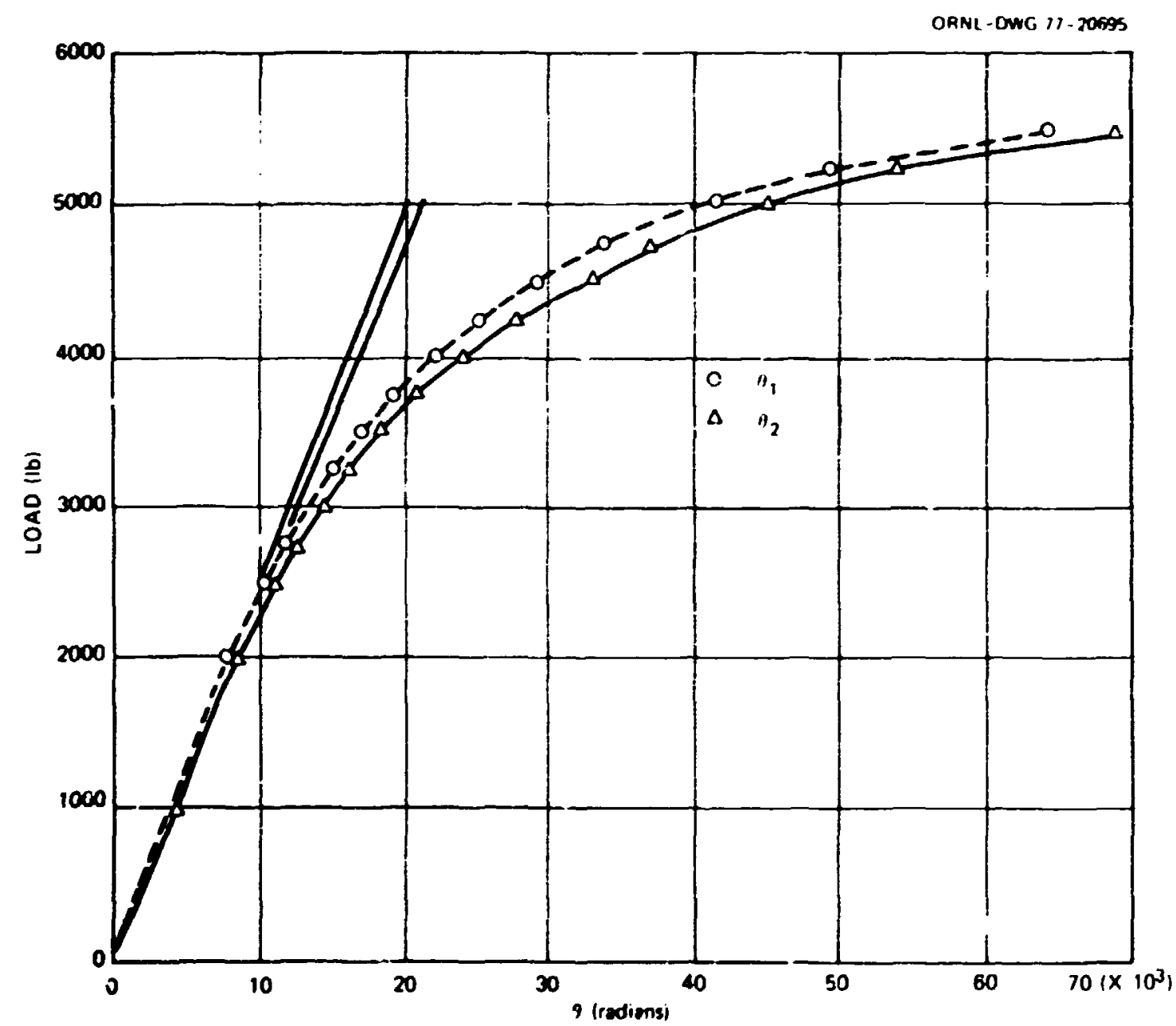

F18. 28. Load-angle of rotation curves for in-plane bending $\left(-M_{z}\right)$ of epecimen PE-15 $\left(11 \mathrm{~b}_{\mathrm{f}}=4.448 \mathrm{~N}\right)$. 


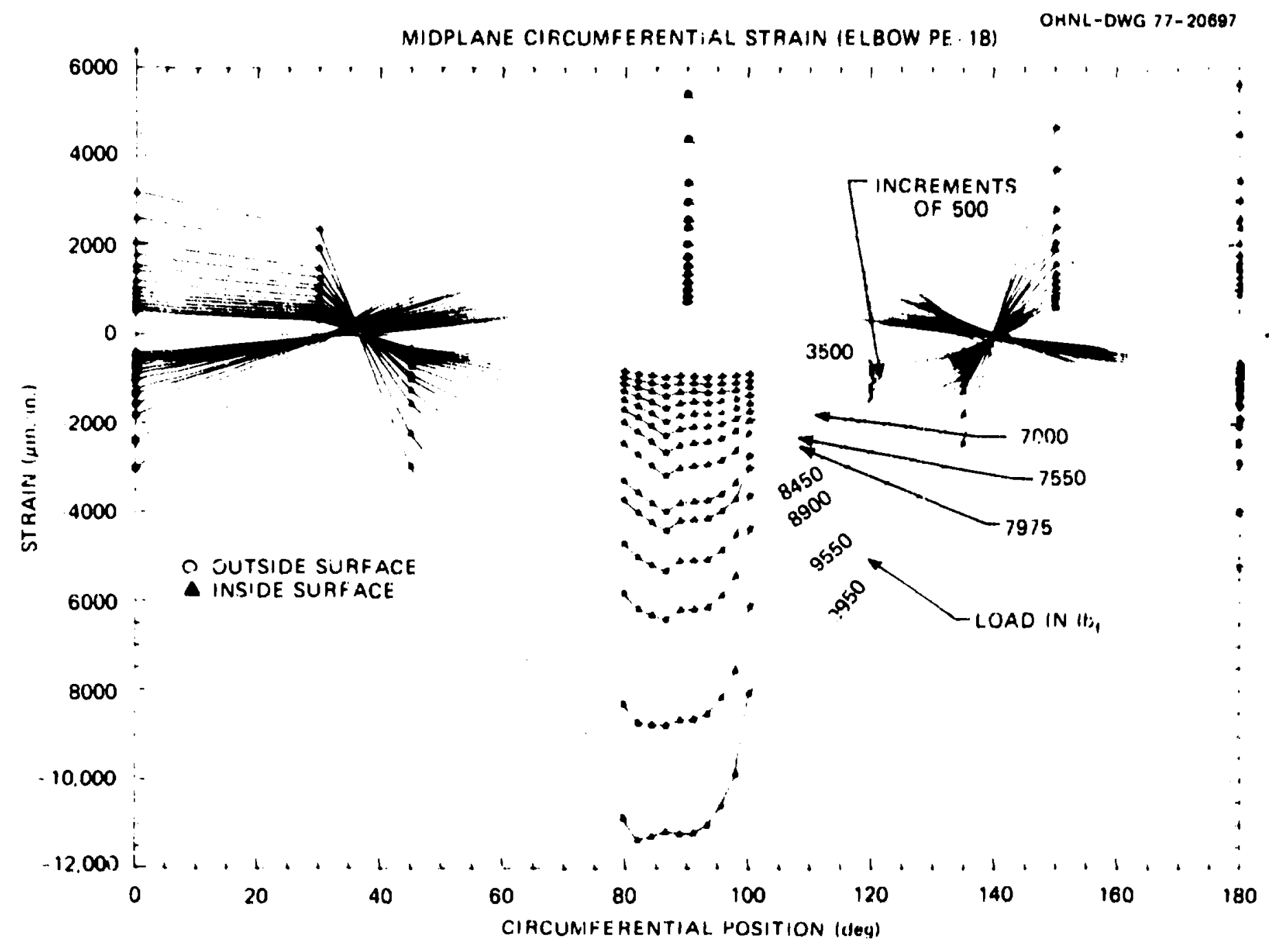

F1g. 29. Circumferential strain vi angular location as function of load for PE-18 ( $\left.1 \mathrm{lb}_{\mathrm{f}}=4.448 \mathrm{~N}\right)$. 


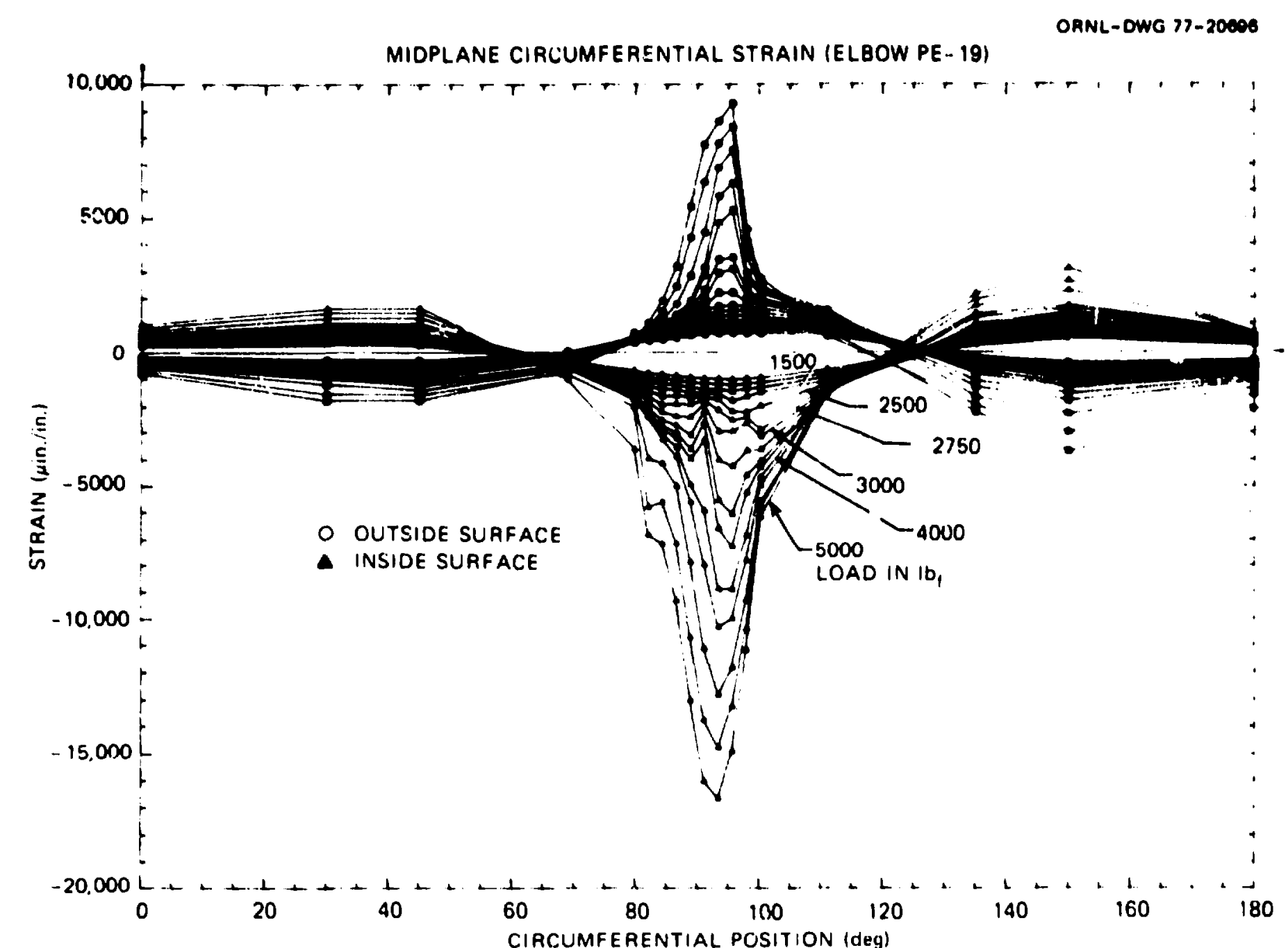

F18. 30. Circumferential strain vs angular location as function of load for PE-19 ( $\left.1 \mathrm{lt}_{\mathrm{f}}=4.448 \mathrm{~N}\right)$. 
Load-strain curves for specigens PE-17 through -20 are given in Figs. 31 through 34. These curves are for gages mounted at or near the maximum strain point or: the inside surface, except tCI PE-20 where data from a gage on the outer surface are plotted. The strain gage numbers correspond to those shown in Figs. 7 and 8.

Birefringent and brittle lacquer coatings were used on the tensile sides of two specimens which were subjected to out-of-plane loadings. In both cases, the region of maximum tensile stress was indicated to be

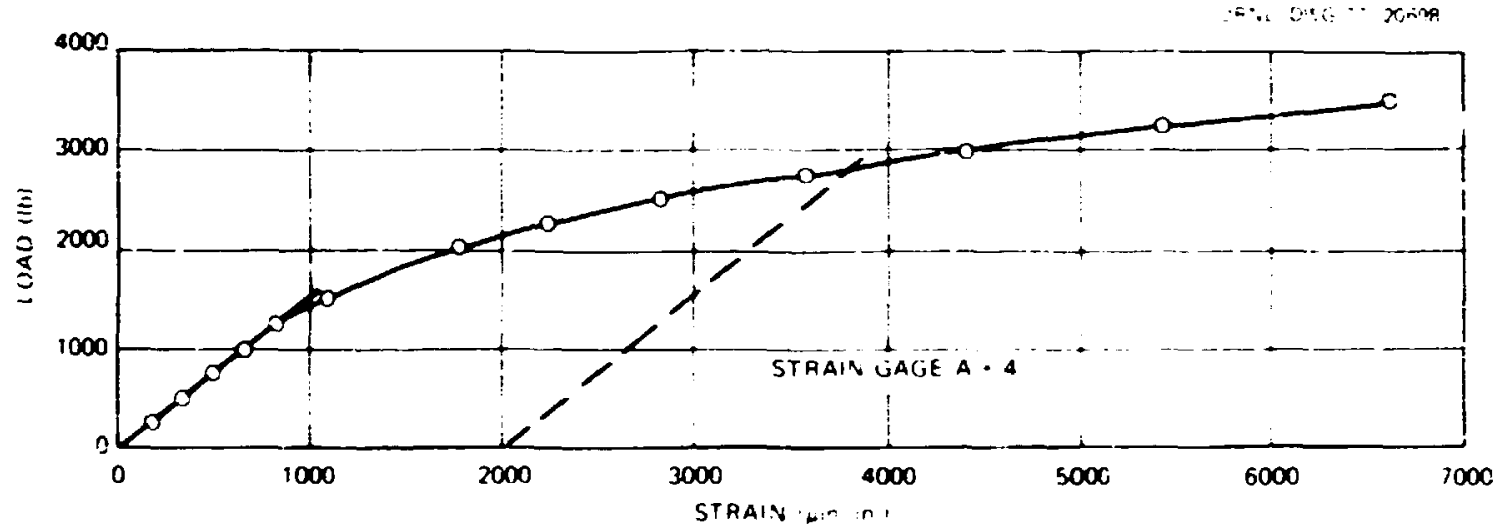

Fig. 31. Load-strain data for in-plane bending $\left(M_{z}\right)$ of specimen $\mathrm{PE}-17$ ( $1 \mathrm{in}$. $=25.4 \mathrm{~mm} ; 1 \mathrm{lb}_{\mathrm{f}}=4.448 \mathrm{~N}$ ).

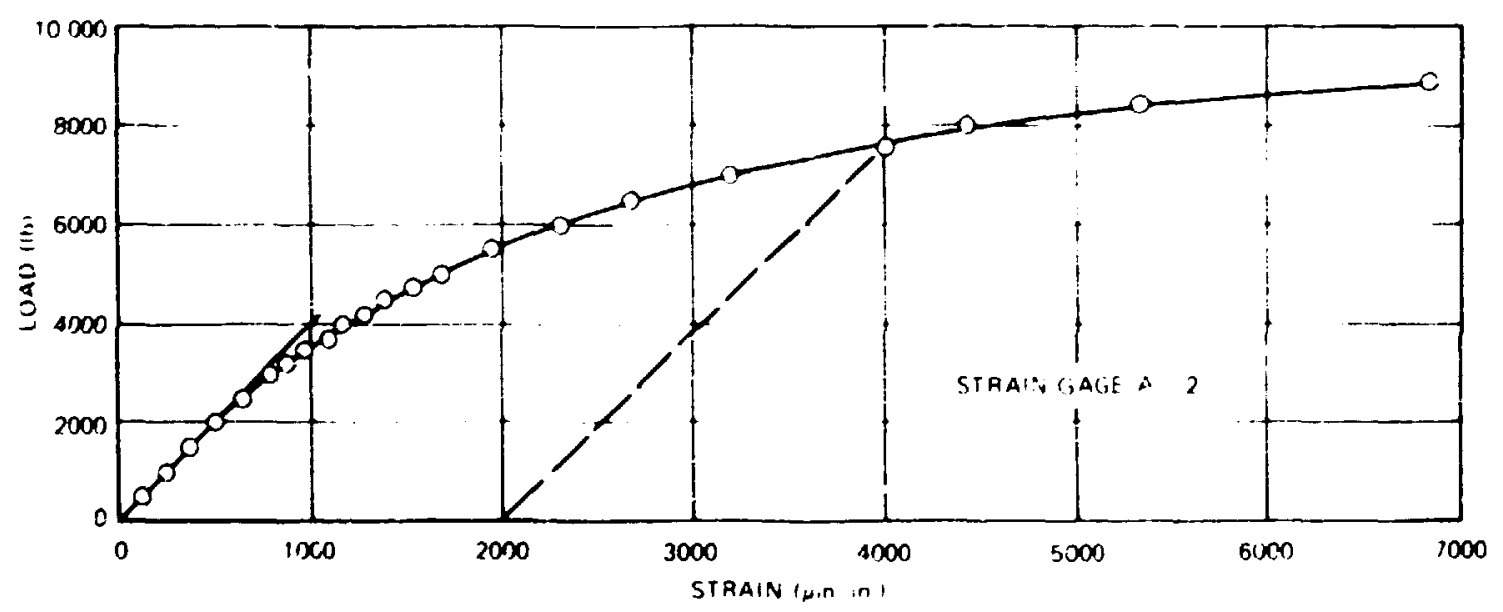

Fig. 32. Load-strain data for in-plane bending $\left(-M_{z}\right)$ of specimen $P E-18$ ( 1 in. $\left.=25.4 \mathrm{~mm} ; 11 \mathrm{~b}_{\mathrm{f}}=4.448 \mathrm{~N}\right)$. 


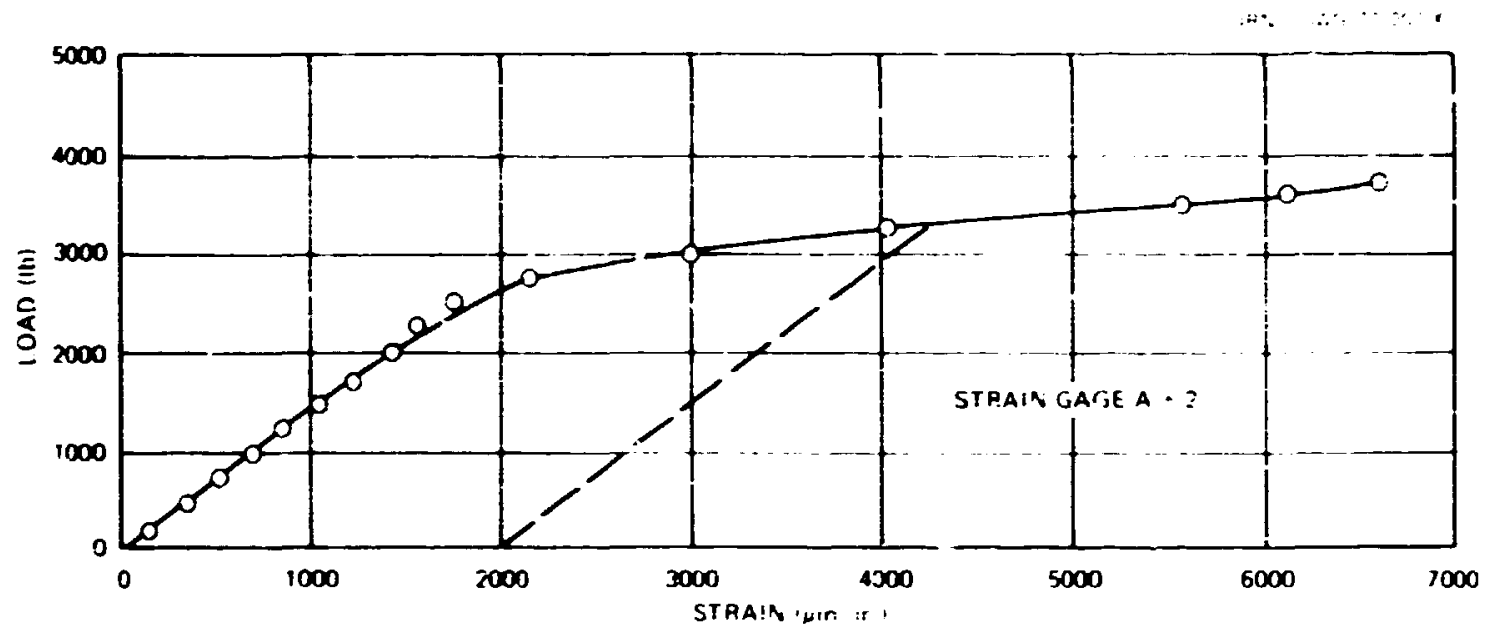

Fig. 33. Load-strain data for in-plane bending $\left(-M_{2}\right)$ of specimen PE-19 ( 1 in. $\left.=25.4 \mathrm{~mm} ; 1 \mathrm{lb}_{\mathrm{f}}=4.448 \mathrm{~N}\right)$.

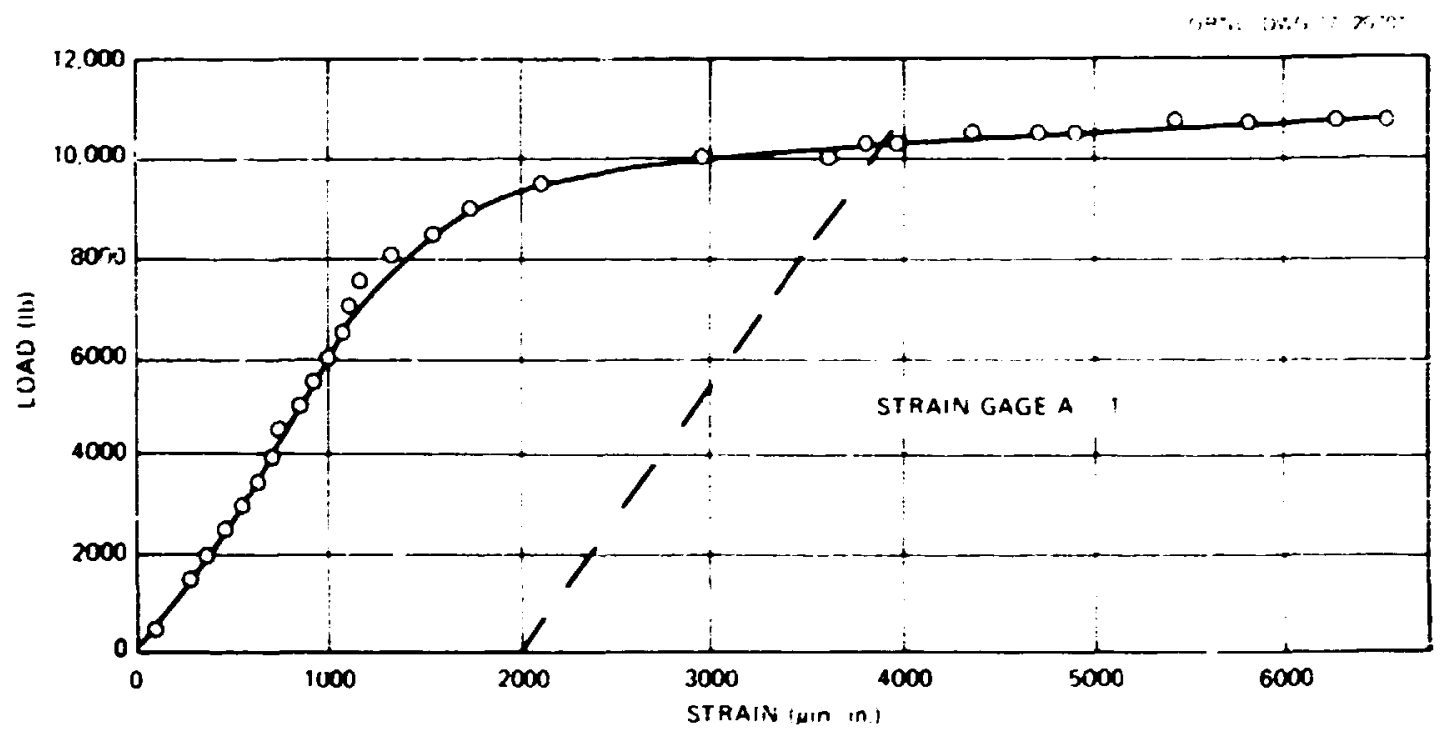

Fig. 34. Load-strain data fer in-plane bending $\left(-H_{z}\right)$ of spectmen PE-20 ( 1 in. $=25.4 \mathrm{~mm} ; 1 \mathrm{lb}=4.448 \mathrm{~N}$ ).

essentially at the midplane or toward the concave side of the elbow. These observations are in line with results to be expected on the basis of elastic analyses. " The brittle lacquer coating revfaled a region of maximum tensile stress approximately $38.1 \mathrm{~mm}(1 / 12 \mathrm{in}$.) wide and $304.8 \mathrm{~mm}$ (12 in.) in length along the surface at the midplane of $P E-15$, which was subjecred to in-plane loading. 
A dimensional survey ${ }^{*}$ on selected compercial pipi:1g components vas conducted at ORN; this survey indicated that the maximum measured o:ality for 161.6-mm (4-in.) sched-40 elbows was about 1.0\%. The maximum ovality meisured for the first I' carbon steel specimens after test in tilis study was $6.5 \%$ for PE-1, which had bec.l suojected to an in-plane bending moment. The stainless steel elbow, PE-15, had pretest ovalities of $1.0 \%$ at the ends and $2.4 \%$ at the $45^{\circ}$ plane; after test, these ovalities were 5.3 and $10 \%$, respectively. The post test ovality at the $45^{\circ}$ plane for the second stainless steel elbow, PE-16, was $9.4 \%$.

Dimensional data for $\mathrm{FE}-17$ through -20 were obtained before and after testing. These data included both didmeters and thicknesses measured at the loaded and the fixed end and at the $45^{\circ}$ plane of the elbow. (See the appendix.) All dimensions prior to test were within the limits given by applicable standards. Postest cvalities are given in Table 3; the largest was $14.5 \%$ for PE-1\%, the sched-80 stainless steel elbow. The pretest ovalities were about $1 \%$ or less.

Table 3. Posttest ovalities

\begin{tabular}{|c|c|c|c|}
\hline \multirow{2}{*}{$\begin{array}{l}\text { Specimen } \\
\text { No. }\end{array}$} & \multicolumn{3}{|c|}{ Ovalicy $(\%)$} \\
\hline & $\begin{array}{l}\text { Loaded } \\
\text { end }\end{array}$ & $\$ 5^{\circ}$ piane & $\begin{array}{c}\text { Fixed } \\
\text { end }\end{array}$ \\
\hline $\mathrm{PE}-17$ & 4.7 & 9.3 & 5.4 \\
\hline $\mathrm{PE}-18$ & 4.2 & 14.5 & 5.1 \\
\hline$P E-19$ & 5.6 & 7.6 & 5.9 \\
\hline$P E-20$ & 6.3 & 12.6 & 8.2 \\
\hline
\end{tabular}

It is instructive to examine the extent of the region of initial linear (elastic) response for each specimen. The furces, or loads, corresponding to the point of departure from linear response are listed in Table 4. The strain-gage results are representative values ubtained from the gages used, and the two values obtained from the di..l indicators are listed for all specimens. There is reasonably gond agreement 
Table 4. Experimentally determined forces corresponding to departure from inear response

\begin{tabular}{|c|c|c|c|c|c|}
\hline \multirow{2}{*}{$\begin{array}{l}\text { Test } \\
\text { No. }\end{array}$} & \multirow{2}{*}{$\begin{array}{l}\text { Type of } \\
\text { load }\end{array}$} & \multirow{2}{*}{ Type of elbow } & \multicolumn{3}{|c|}{$\begin{array}{c}\text { Force (1b) at departure } \\
\text { from linear response }\end{array}$} \\
\hline & & & $\begin{array}{l}\text { Strain } \\
\text { gage }\end{array}$ & DI 1 & DI 2 \\
\hline PE-1 & $H_{2}$ & Sched-40 LR & 3250 & 3500 & 3500 \\
\hline$P E-2$ & $H_{2}$ & Sched-40 LR & 3500 & 3750 & 3750 \\
\hline PE-3 & $\mathrm{H}_{\mathrm{j}}$ & Sched-40 LR & 3500 & 3750 & 3750 \\
\hline PE-4 & $+H_{z}+P$ & Sched-40 LR & & 2500 & 2400 \\
\hline$P E-5$ & $\mathrm{H}_{2}+\mathrm{P}$ & Sched-40 LR & & 2800 & 3000 \\
\hline PE-6 & $M_{y}+P$ & Sched-40 iR & & 3000 & 3000 \\
\hline PE-7 & $+H_{2}$ & Sched-80 LR & & 7000 & 7500 \\
\hline$P E-8$ & $\mathrm{M}_{2}$ & Sched-80 LR & 5000 & 6000 & 5250 \\
\hline PE-9 & $\mathbf{M}_{\mathbf{y}}$ & Sched-80 LR & & 5000 & 5000 \\
\hline$P E-10$ & $+M_{2}$ & Sched-40 SR & 3400 & 3200 & 3000 \\
\hline PE-11 & $-M_{z}$ & Sched-40 SR & 4050 & 4200 & 4100 \\
\hline PE-12 & $M_{y}$ & Sched-40 SR & & 4000 & 3850 \\
\hline PE-13 & $+H_{z}+P$ & Sched-40 SR & & 2500 & 2500 \\
\hline PE-14 & $M_{y}+P$ & Sched-40 SR & & 2750 & 3000 \\
\hline$P E-15$ & $M_{2}$ & Sched-40 LR & 1200 & 2200 & 2100 \\
\hline PE-16 & $-M_{z}$ & Sched-40 LR & & 1900 & 1800 \\
\hline PE-17 & $H_{2}$ & Sciled-40 SR & 1150 & 1500 & 1500 \\
\hline PE- 18 & $M_{z}$ & Sched-80 LR & 2700 & 3000 & 3300 \\
\hline$P E-19$ & $-M_{2}$ & Sched-40 SR & 1400 & 2050 & 2150 \\
\hline PE-20 & $M_{2}$ & Sched-80 SR & 3700 & 4000 & 4000 \\
\hline
\end{tabular}

betroen the values for a given specimen in all cases except for the low straln-gage value for specimen PE-15.

The data in Table 4 for carbon steel elbows show that combinations of Internal pressure and external force loading resulted in departures from lineartty at loads which were lower than those for external forces 
alone. A comparison of the values obtained from dial-indicator surves shows that the loads at the onset of nonlinear response for the stainless steel elbows are frum 0.4 to 0.5 of those for corresponding carbon steel elbows subjected to the same loading conditions and with the same radii and iall thcknesses. These differences are not reflections of the differences in $0.2 \%$ of fet yield stresses.

\section{INTERPRETATICA OF RESULTS}

The determination of plastic collapse loads from tests on real structures for comparison with limit analysis calculations has been the subject of many discussions. ${ }^{1,5-10}$ In general, a force-displacement curve for a structure displays a region of linear responsc, a transition region where the behavior changes from mainly elastic to mainly plastic, and a region in which a small increase in load produces a large change in displacement. The concept of plastic collapse for an ideal structure is the concition where deflections can increase without limit while the load is held constant. Thus, the selection of the collapse load for a real structure requires careful study.

Demir and Drucker, 1 in their studies on cylindrical specimens subjected to outwardly directed ring loadings, defined the limit load as the load at which the measured deflection was three times the extrapolated elastic deflection. The limit loads obtained in this way were in excellent agreemert with theoretical predictions. According to the authors, che factor 3 was selected arbitrarily and represent ad a compromise between the larger and smaller factors which are sometimes used.

A second method for establishing the limit load is to use the point of intersection of a line drawn tangent to the initial portion of the force-deflection curve (the elastic response region) and a line drawn tanger, to the straight-line portion of the curve in the piastic region. of course this method depends upon the existence of a region in the predominantly plastic response range for which the deflection is directly proportional to the load, and thus the experiment must be carried beyond the transition region, and geometry change efiucts mus': be absent. A 
third method is to determine the load at 0.22 offset strain from a loadstrain diagram where the strains are measured by strain gages locatid in the high-stress or -strair. regions of the structure.

The results corresponding to the intersecting line, or tangent, method described above are very close to those obtained using the total deflection criterion in the case of the experiments by Demir and Drucker. Ti:us, the two methods are essentially equivalent for their case. Other investigators ${ }^{6}, 7,11$ have shown that the tangent method gives results which compare favo" lbly with salculated limit-load values for other shell structures and loadings. In addition, reasonable agreement has also been found between the load at $0.2 \%$ offset strain and the load obtained using the tangent method. ${ }^{7,9,10}$

The results from the series of tests on 152.4-mm (6-in.) elbows indicated continuous decreases in deformation resistance with increase in load. However, as mentioned in the preceding section, there were cases in which limitations on maximum loading ram travel and/or dial indicator travel precluded obtaining curves which extended far enough into the plastic region to show linear response at the higher loads. In addition, strain-gage results were obtained only for a few cases. Thus a method patterned after thai used by Demir anid Drucker was established for obtaining limit-ioad values on the basis of total deflection. The means for selecting the deflection values is described below.

Results for those specimens where collapse loads could be obtained ty the $0.2 \%$ offset strain method, by the tangent mathod, or by both are given in Table 5. Values were determined by the tangent method for toth load-deflection curves for $\mathrm{PE}-14,-15,-18,-13$, and -20 . A comparison of the results obtained by the two methods for specimens PE-1, $-2,-11$, and -20 shows very good agreement between strain gage $(0.2 \%$ offset $)$ and dial-indicator (tangent) data. There is also close agreement between the strain-gage result for $\mathrm{PE}-15$ and the dial indicator values. The gtrain gage results are low for $P E-17,-18$, and -19 . It is noted that the loads which were determined from the load-strain and the load-deflection curves (Table 4) and which correspond to the ons $t$ of nonlinear response were generally found to be In good agreement for all but one specimen, PL-15, where there was a significant difference between these values. 
Tabie 5. Experimentally determined loads using selected criteria

\begin{tabular}{|c|c|c|c|c|c|}
\hline \multirow{3}{*}{$\begin{array}{c}\text { Test } \\
\text { No. }\end{array}$} & \multirow{3}{*}{$\begin{array}{l}\text { Type of } \\
\text { load }\end{array}$} & \multirow{3}{*}{ Type of elbow } & \multicolumn{3}{|c|}{$\begin{array}{c}\text { Collapse } \text { load }^{a} \\
\text { (1b) }\end{array}$} \\
\hline & & & \multirow{2}{*}{$\begin{array}{l}0.2 \% \text { offset } \\
\text { strain }\end{array}$} & \multicolumn{2}{|c|}{ Tangent method } \\
\hline & & & & DI 1 & DI 2 \\
\hline PE.-1 & $+H_{2}$ & Sched-40 LR & 7,100 & & 6,875 \\
\hline $\mathrm{PE}-2$ & -11 & Sched-40 LR & 5,700 & & 6,175 \\
\hline$P E-3$ & $i t y$ & Sched-40 LR & 7,900 & & \\
\hline PE-5 & $M_{2}+P$ & Sch $=d-40$ LR & & 7,925 & \\
\hline $\mathrm{PE}-6$ & $M_{y}+P$ & Sched 40 LR & & 7,250 & \\
\hline $\mathrm{PE}-7$ & $+M_{z}$ & Sched-80 LR & & 13,750 & \\
\hline $\mathrm{PE}-8$ & $\mathrm{H}_{z}$ & Sched-90 LR & 11,900 & & \\
\hline PF-9 & $\mathrm{M}_{\mathrm{y}}$ & Sched-30 LR & & 12,900 & \\
\hline$P E-11$ & $-i x_{2}$ & Sched-40 SR & 5,150 & & 5,150 \\
\hline$P \bar{E}-13$ & $+M_{z}+P$ & Sched-40 SR & & 6,800 & \\
\hline PE-14 & $M_{y}+P$ & Sched-40 SR & & 6,200 & 6,750 \\
\hline$P E-15$ & $M_{2}$ & Sched-40 LR & 4,400 & 4,160 & 4,160 \\
\hline$P E-16$ & $-M_{2}$ & Sched-40 LR & & 4,475 & \\
\hline $\mathrm{PE}-17$ & $\mathrm{M}_{2}$ & Sched-40 SR & 2,850 & 3,700 & \\
\hline$P E-18$ & $-M_{2}$ & Sched-80 LR & 7,600 & 7,100 & 9,100 \\
\hline PE -19 & $\mathrm{M}_{2}$ & Sched-40 SR & 3,300 & 4,750 & 5,000 \\
\hline$? \mathrm{E}-20$ & $\mathrm{H}_{2}$ & Sched-8O SR & 10,700 & 10,220 & 10,300 \\
\hline
\end{tabular}

It is important to note that stress-strain curves for carbon steel in the strain range of interest in this report are clore to those corresponding to the elastic, perfectly plastic behavior assumed in the development of 1 imit analysis theory. But stainless steel, which shows a gradual transition from elastic to elastic-plastic behavior, exhibits resporse characteristics that are significantly different from the idealized behavior assumed. For this reason, it is justifiable to 
establish the method of limit-load determination based on the response data for the carbon steel specimens only.

Since the loads for $0.2 \%$ of fet strain and those determined from load-deflection curves through the use of the tangent method itave been show: by others to Elve good comparisons with calculated limit loads, the agreement found between results obtained by these methods for the carbon steel specimens in this series of tests suggests that the tangent or an equivalent metho' can properly be used here for limit-load definition. In order to establish an equivalent method, the extrapolated elastic deflection, $\delta E$, was subtracted from the total deflection corresponding to the limit load in each case where the tangent method couid be used. The difference, or the nonelastic deflection (denoted by $a \delta E$ ), was divided by the elastic deflection to determine "a" and repre:sentative a values were selected. (Note that Deit and Drucker used $a=2$.) These selected values. 1 isted in Table 6 , were then used to determine the collapse loads for each spectmen. The collapse loads determined in this way are those assocjted with the " $\mathrm{V}$ " marks on the curves in Figs. 10 through 21. The collapse moments, $M^{*}$, at the ends of the elbows are the pro!luct, to the nearest $113.0 \mathrm{~N} \cdot \mathrm{m}$ (1000 in.-1b), of the collapse loads and the moment arms; these moments are also given in Table 6 .

The collupse load for $\mathrm{PE}-3$, as indicated in Table 6, is significanty less than the lcad determined by the $0.2 \%$ of fset strain method (Table 5 ). This is also true for the collapse loads listed in Tables 5 and 6 for specimen PE-1j. The magnitude of this difference for PE-15 is about the same as that for $1 E-3$. The difference for $P E-3$ may be attributable to failure to locate the strain gages in the higil strain region, as noted in the preceding section. However, this is not the contributing factor in the case of the stainless steel elbow, PE-15. The collapse loads for this specimen determined by the tangent method from the load vs $\theta_{1}$ and the load vs $\theta_{2}$ curves (Fig. 28) ire the same, 18.5 k: (4160 Ib). The corresponding values obtained from these load-vs- $\theta$ curves using the displacenent method adopted for this study are $15.57 \mathrm{kN}(3500 \mathrm{lb})$ and $15.79 \mathrm{kN}(3550 \mathrm{lb})$.

Thus, the ilist set of values for PE-15 are in reasonable agreement with the 0.27 of fset strain value (Table 5), while the latter values agree with those given in Table 6 which were obtained from the load-deflection curves. 


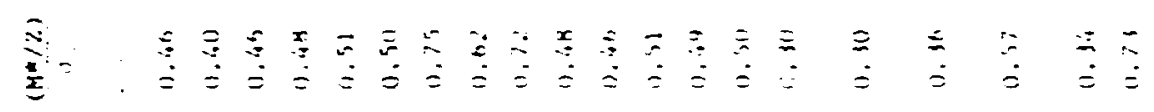

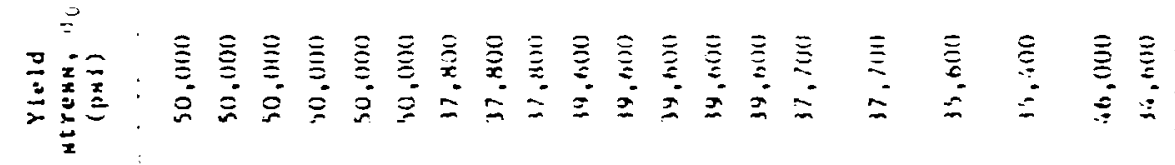

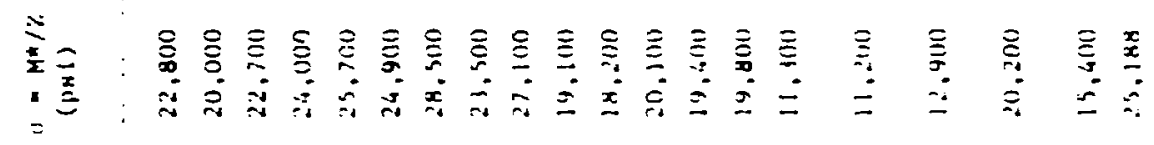

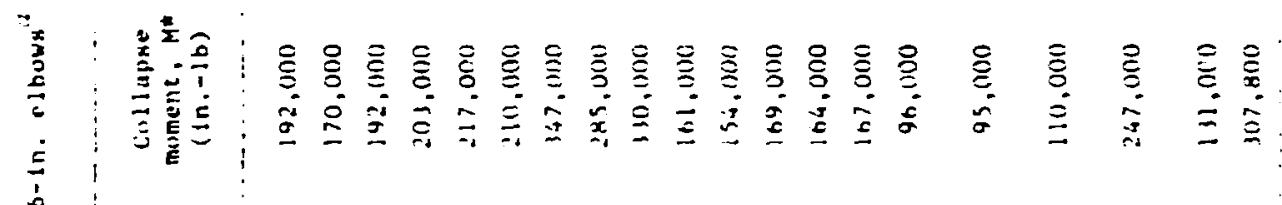

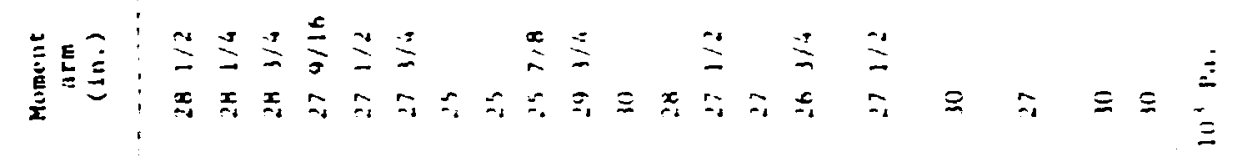

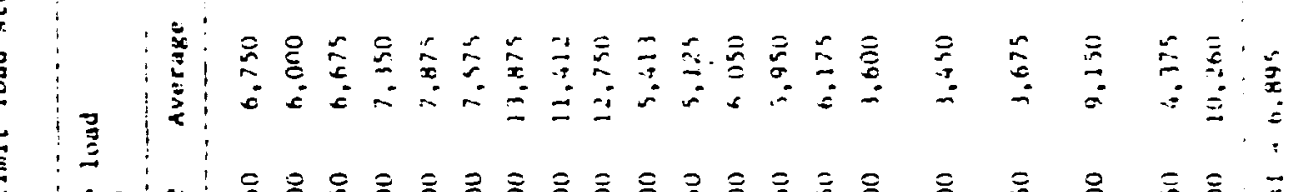

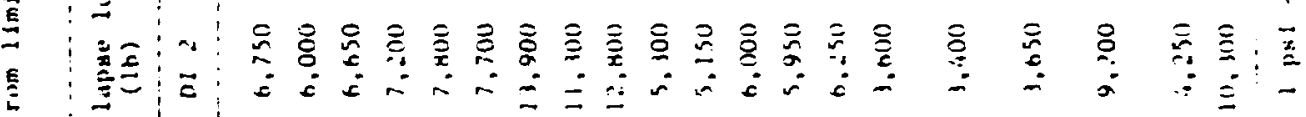

- -

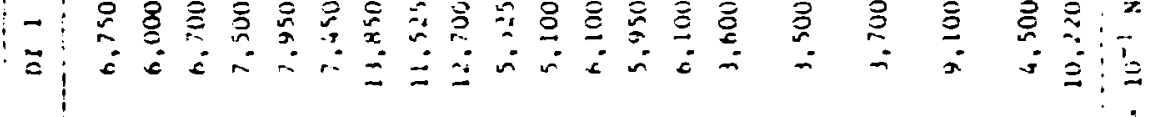

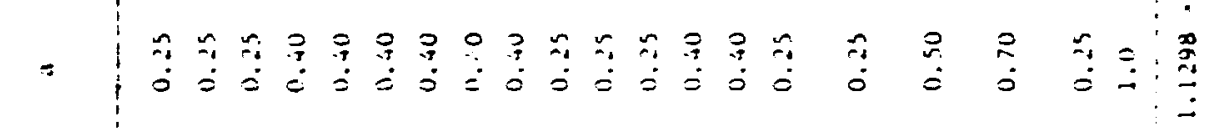

$\dot{5}$

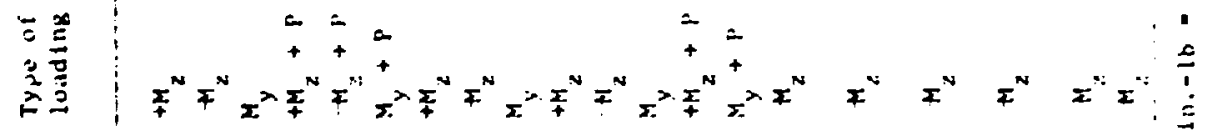

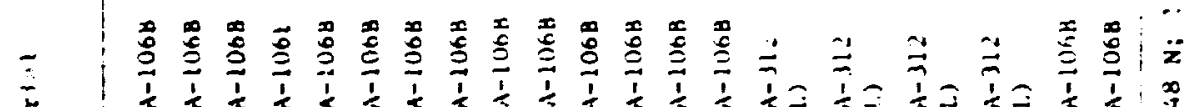

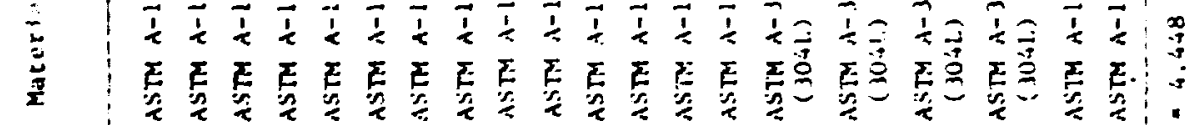

$\div$

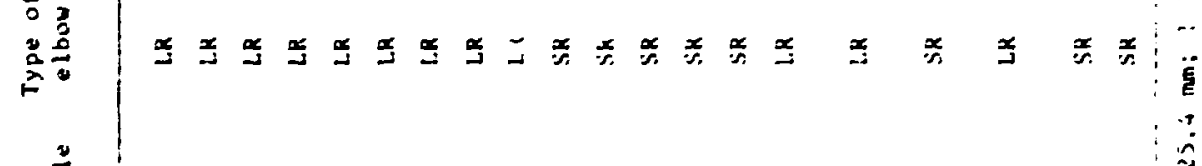

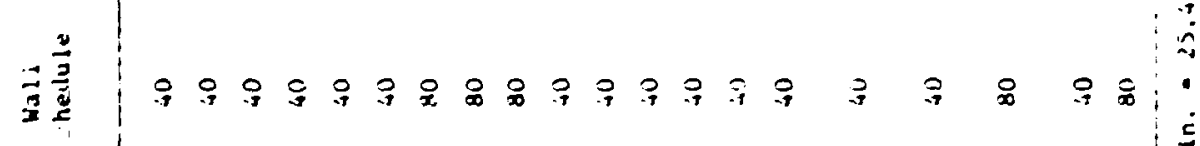

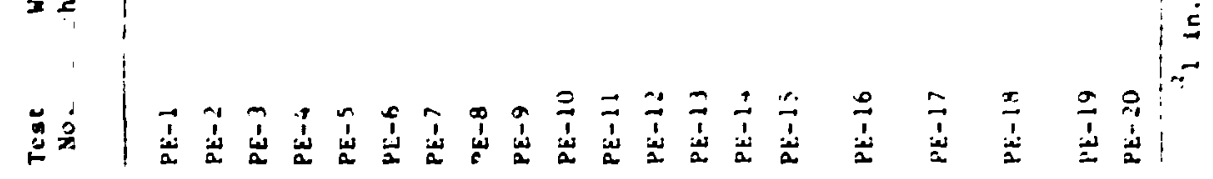


Further, since essentially the same results are obtained from load-vsdeflection curves as from load-vs-angle of rotation curves, the selection of correlating parameters has little influence in this case.

The maximum bendi.ag stresses in the pipe extensions (the stresses, $\sigma=M^{*} / 2$, corresponding to the collapse moments, $M^{*}$ ) were also calculatad and listed in Table 6 . The symbol $Z$ denotes the section modulus for the pipe extension, or the elbow.

Because of the differences in yield stresses for the elbows (Table 1). comparisons must be made on the basis of the values in the last colum of Table 6. These values, whin range from 0.34 to 0.75 for carbon steel ( 0.30 to 0.57 for stainless steel), can be interpreted as indicating the margins of safety with respect to the onset of yield in straight runs of pipe.

The results given in Table 6 show that the ratio of the maximum bending stresses at collapse to the yield stresses are generally slightly larger for the short-radils sched-40 carbon steel albows than for the sched-40 long-radius elbows for a given loading. In general, the addition of internal pressure increases the collapse moment, although the load at the onset of nonlinear response is decreased as noted in the precting section. The ratio of maximum stress at collapse to yield stress is increased with increased wall thickness, and the collapse moments for stainless steel tend to be much smaller than those for carbon steel.

To give additional perspective, loads ccrresponding to first yield $\left(\mathrm{L}_{0.2 \%}\right)$, the proportional 1 imit $\left(\mathrm{L}_{\mathrm{PL}}\right)$, the onset of nonlinear response as determined from strain gage readings $\left(\mathrm{L}_{\mathrm{SG}}\right)$, " and the onset of nonInear response as determined from dial gages $\left(L_{D I}\right)$, were considered. These are listed in Table 7 along with the bend characteristic parameter $\lambda$ as given by

$$
\lambda_{1}=-\frac{t R}{r^{2} \sqrt{1-v^{2}}},
$$

\footnotetext{
*Note that only specimens with inside gages were considered, except for $P E-15$.
} 
Table i. Sureary ut idads"

\begin{tabular}{|c|c|c|c|c|c|c|c|c|c|c|}
\hline \multirow[t]{2}{*}{$\begin{array}{l}\text { Test } \\
\text { Sin. }\end{array}$} & \multirow[t]{2}{*}{$\begin{array}{l}\text { Type of } \\
\text { loading }\end{array}$} & \multirow[t]{2}{*}{$:$} & \multirow[t]{2}{*}{$\because$} & \multirow[t]{2}{*}{$R_{i} \mathbf{r}$} & \multirow[t]{2}{*}{ - } & \multicolumn{2}{|c|}{$\begin{array}{c}\text { Aad at onset } \\
\text { of yield } \\
\text { (lb) }\end{array}$} & \multicolumn{2}{|c|}{$\begin{array}{l}\text { Load at inset } \\
\text { of nonifinearit: } \\
\text { (lb) }\end{array}$} & \multirow{2}{*}{$\begin{array}{l}\text { Liatt } \\
\text { load } \\
(15)\end{array}$} \\
\hline & & & & & & $i_{0 .: 5}$ & LPL. & ${ }^{L}{ }_{S C}$ & ${ }^{L} \mathrm{DI}$ & \\
\hline PE-1 & $+4 z$ & 0.262 & 0.250 & $2.8 \div$ & 0 & $28 \mathrm{is}$ & & & 3500 & 6.750 \\
\hline PE-2 & $H_{2}$ & 0.262 & $0 .: 50$ & 2.84 & 0 & 2838 & & & $3: 50$ & 0.500 \\
\hline PE-3 & My & 0.262 & 0.250 & 2.84 & 0 & 3414 & & & 3750 & 6,675 \\
\hline PE-: & $H_{z}+P$ & 0.262 & 0.250 & 2.34 & 0.0045 & $2\{\gg\}$ & & & 2450 & 7,350 \\
\hline PE- 5 & $-M_{2}+P$ & 0.262 & 0.250 & 2.86 & $0 . \cos =5$ & 2198 & & & 2900 & 7.875 \\
\hline PE-6 & $x_{y}+p$ & 0.262 & 0.250 & 2.64 & 0.0045 & 2681 & & & 3000 & 7.575 \\
\hline$P E-i$ & $M_{2}$ & 0.425 & 0.405 & 2.91 & 0 & 4866 & & & 725 & 13.875 \\
\hline PE-B & -12 & 0.425 & 0.405 & 2.91 & 0 & $\therefore 866$ & & & 5625 & $11,+12$ \\
\hline PE- 9 & $\mathrm{M}_{\mathrm{y}}$ & 0.425 & 0.405 & 2.91 & 0 & 3610 & & & 5000 & 12,750 \\
\hline$P E-10$ & $+4 z$ & 0.375 & 0.167 & 1.89 & 9 & 1558 & & & 3100 & 5,413 \\
\hline PE-II & $H_{2}$ & 0.175 & 0.167 & 1.89 & 0 & 1365 & & & 4150 & 5.125 \\
\hline$P E-12$ & $y_{y}$ & 0.175 & 0.167 & 1.89 & 0 & 2073 & & & 3925 & 6.050 \\
\hline$P E-13$ & $+\frac{4}{z}+P$ & 0.175 & 0.167 & 1.89 & 0.0019 & 1065 & & & 2500 & 5.950 \\
\hline PE-1: & $M_{y}+P$ & 0.175 & 0.167 & 1.89 & $; .0019$ & 1363 & & & 2875 & 6,175 \\
\hline PE-15 & -4 & 0.262 & $0.25 ?$ & 2.56 & 0 & 2260 & 809 & 1200 & 2150 & 1.620 \\
\hline$P E-: 4$ & $-y_{2}$ & 0.262 & 0.250 & 2.84 & 0 & 2198 & 187 & & 1850 & 3.450 \\
\hline$P E-17$ & $\mathrm{H}_{2}$ & 0.175 & 0.167 & 1.89 & 0 & 1389 & 624 & 1130 & $1: 00$ & 3.675 \\
\hline$P E-18$ & +12 & $0 . \div 25$ & .405 & 2.91 & 0 & $\therefore 216$ & 2164 & 2700 & 3150 & 9.150 \\
\hline$P S-19$ & -4 & 0.175 & 0.167 & 1.89 & 0 & 1795 & & 1500 & 2100 & $\therefore 373$ \\
\hline PF- 20 & ${ }^{-1} 2$ & 0.286 & 0.270 & 1.94 & 0 & 2710 & & 3700 & 4000 & 10.260 \\
\hline
\end{tabular}

or

$$
\lambda_{2}=\frac{t R}{r^{2}}
$$

Also given in Table 7 are the radius ratio $R / r$, and the pressure parameter,

$$
\Psi=\frac{P^{2}}{E R t}
$$

In these equations, $t$ is the thickness of the elbow, $r$ is the mean radius, $R$ is the bend radius, $V 18$ Polsson's ratio, $E$ ts the elastic 
zraulus, and $P$ is pressure. The last columan of Table $i$ gives the limit luads. The loads corresponding to onset of yielding were calculated ustag stress indices dertued from Ref. 12 and assuming that yield is deternined by the maximum shear stress. The $L_{P L}$ values for the stainless steel specimens are lov compared with those for $\mathrm{L}_{\mathrm{SG}}$. For PE-19 and -20 , the $L_{0.27}$ and $L_{S G}$ values are in fair agreement.

Homes corresponding to the loads given In Table 7 were normalized using $M^{*}$, the plastic collapse moment in each case, and the resultint values are listed in Table 8 . The last colum of this table give: the ratio of the plastic collapse moment to the theoretical plastic collapse

Table 8. Summary of moment ratios

\begin{tabular}{|c|c|c|c|c|c|c|c|c|}
\hline \multirow{2}{*}{$\begin{array}{l}\text { Test } \\
\text { No. }\end{array}$} & \multirow{2}{*}{$\begin{array}{l}\text { Type of } \\
\text { loading }\end{array}$} & \multirow{2}{*}{$i^{2}$} & \multirow{2}{*}{ Rir } & \multicolumn{2}{|c|}{$\begin{array}{l}\text { Onset of } \\
\text { yield }\end{array}$} & \multicolumn{2}{|c|}{$\begin{array}{c}\text { Onset of } \\
\text { nonl inearity }\end{array}$} & \multirow{2}{*}{$\begin{array}{l}\text { Straight pipe } \\
\text { normalization } \\
\frac{y *}{y:}\end{array}$} \\
\hline & & & & $\frac{y_{0.2 \%}}{M^{*}}$ & $\frac{M_{P L}}{M \star}$ & $\frac{M_{S C}}{M^{*}}$ & $\frac{M_{D I}}{y^{\star}}$ & \\
\hline PE-1 & $+M_{2}$ & 0.250 & 2.84 & 0.42 & & & 0.52 & 0.36 \\
\hline PE-2 & $-H_{2}$ & 0.253 & 2.84 & 0.41 & & & 0.63 & 0.30 \\
\hline PE-3 & $M_{y}$ & 0.250 & 2.84 & 0.51 & & & 0.56 & 0.34 \\
\hline PE-4 & $+M_{z}+P$ & C. 250 & 2.84 & 1). 30 & & & 0.33 & c. 38 \\
\hline $\mathrm{PE}-5$ & $-M_{z}+P$ & 0.250 & 2.84 & 0.29 & & & 0.37 & 0.40 \\
\hline PE-6 & $M_{y}+P$ & 0.250 & 2.84 & 0.35 & & & 0.60 & 0.39 \\
\hline PF-7 & $+i_{z}$ & 0.405 & 2.91 & 0.35 & & & 0.52 & 0.53 \\
\hline PE-8 & $-H_{2}$ & 0.405 & 2.91 & 0.43 & & & 0.49 & 0.46 \\
\hline PE-9 & $M_{y}$ & 0.405 & 2.91 & 0.44 & & & 0.39 & 0.53 \\
\hline PE.-10 & $+M_{z}$ & C.167 & 1.89 & 0.29 & & & $0.5:$ & 0.36 \\
\hline$P E-11$ & $M_{z}$ & 0.167 & 1.89 & 0.30 & & & 0.81 & 0.35 \\
\hline PE- 12 & $M_{y}$ & 0.167 & 1.89 & 0.34 & & & 0.65 & 0.38 \\
\hline PE-13 & $+H_{z}+P$ & 0.167 & 1.89 & 0.18 & & & 0.42 & 0.40 \\
\hline PE-14 & $H_{y}+P$ & 0.167 & 1.89 & 0.22 & & & 0.47 & 0.40 \\
\hline PE-15 & $-M_{2}$ & 0.250 & 2.84 & 0.62 & 0.22 & 0.33 & 0.60 & 0.23 \\
\hline$P E-16$ & $-M_{2}$ & 0.250 & 2.84 & 0.64 & 0.23 & & 0.34 & 0.22 \\
\hline PE-17 & $-M_{2}$ & 0.167 & 1.89 & 0.38 & 0.17 & 0.31 & 0.41 & 0.27 \\
\hline$P E-18$ & $M_{2}$ & 0.405 & 2.91 & 0.46 & 0.23 & 0.30 & 0.34 & 0.47 \\
\hline PE-19 & $-\mathrm{M}_{2}$ & 0.167 & 1.89 & 0.41 & & 0.34 & 0.48 & 0.25 \\
\hline PE-20 & $H_{2}$ & 0.270 & 1.94 & 0.26 & & 0.36 & 0.39 & 0.54 \\
\hline
\end{tabular}


momeat for straight pipe. The latter is given by: ?

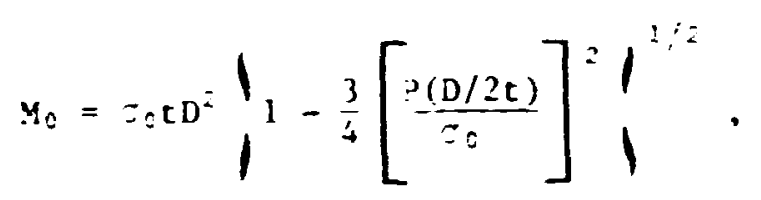

where $D$ is the mean diameter and $P$ is the internal pressure.

Tiie $\tilde{f}$ irst two normalized quantities in Table $8, M_{0.2 \%} / M^{*}$ and $M_{\mathrm{PL}} / \mathrm{M}^{*}$, correspond to reciprocal shape factors (the ratio of the moment at first yield to the fully plastic moment). The shape facter for straight pipe of ela:tic, perfectly plastic material is $4 / \pi$. The ratio $M_{0.2 \%} / M *$ is ploted as a function of $1 / \gamma_{2}$ in Fig. 35. where a dashed 1 ise at $T / 4$ has been draim for reierence. Unique correletious are not identifiable from this plnt; however, lines which are indicative of $f$ ixed $R / r$ are shown. Both $\lambda$ and $R / r$ dependence are indicated; this is also true Esr the results shown in Fig. 36, where $\mathrm{y}_{\mathrm{DI}} / \mathrm{y}^{*}$ is plotteri vs $1 / \gamma_{2}$. In both figures, the points for combined loading fall below those for single loadings. Beyond these similarities, there is essentially no correspondence between the sets of data in Figs. 35 and 36 .

The ratio ${ }^{\mathrm{PL}} / \mathrm{M}^{*}$ is also dependent on $\mathrm{R} / \mathrm{r}$, but. it appears to be independent of $\lambda$. Finally, ${ }_{S G} / M t$ does not show a discernitle dependence on either parameter.

The experimentally determined shape factor is given by $M^{*} / \mathrm{M}_{S G}$, and values obtained range from 2.78 to 3.33 . The shape factor for straight pipe. 1.27, is much lower. A second comparison van be made with experimental values obtained by Gross ${ }^{14}$ from elbows with dimensions similar to those for specimens PE-1 through -6 . In-plane loading corresponding to $-M_{2}$ in the present case was used, and ratios of load causing collapse divided by load causing local yielding (as determined by strain gages) were obtafned for two $152.4-m m(6-\mathrm{in}$.) specimens. These values were 2.06 and 2.11 for $\lambda_{2}$ values of 0.283 and 0.269 , respectfvely, and $R / r$ values of 2.85 and 2.84 . The strain gages used by Gross were mounted at the $45^{\circ}$ plane at $22.5^{\circ}$ intervals around the circumference on both the inside and the outstde surface of the elbow. Because of the spacing and the long gage lengrh, $20.6 \mathrm{~mm}$ (13/16 in.), localized yielding probably was 


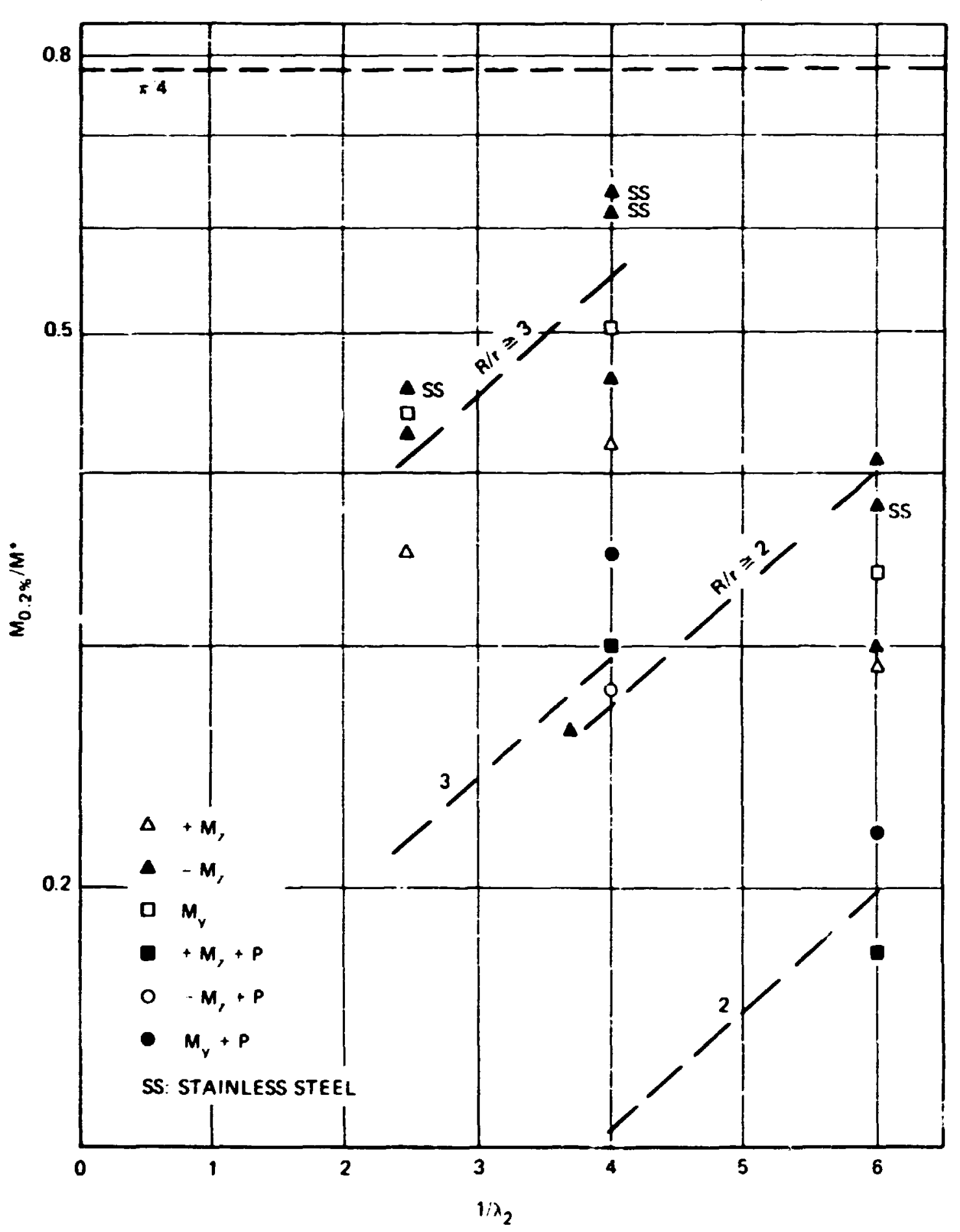

P1g. 35. Calculated moment at onset of ylelding. 
OHSL Dirg $/ i \cdot 26703$

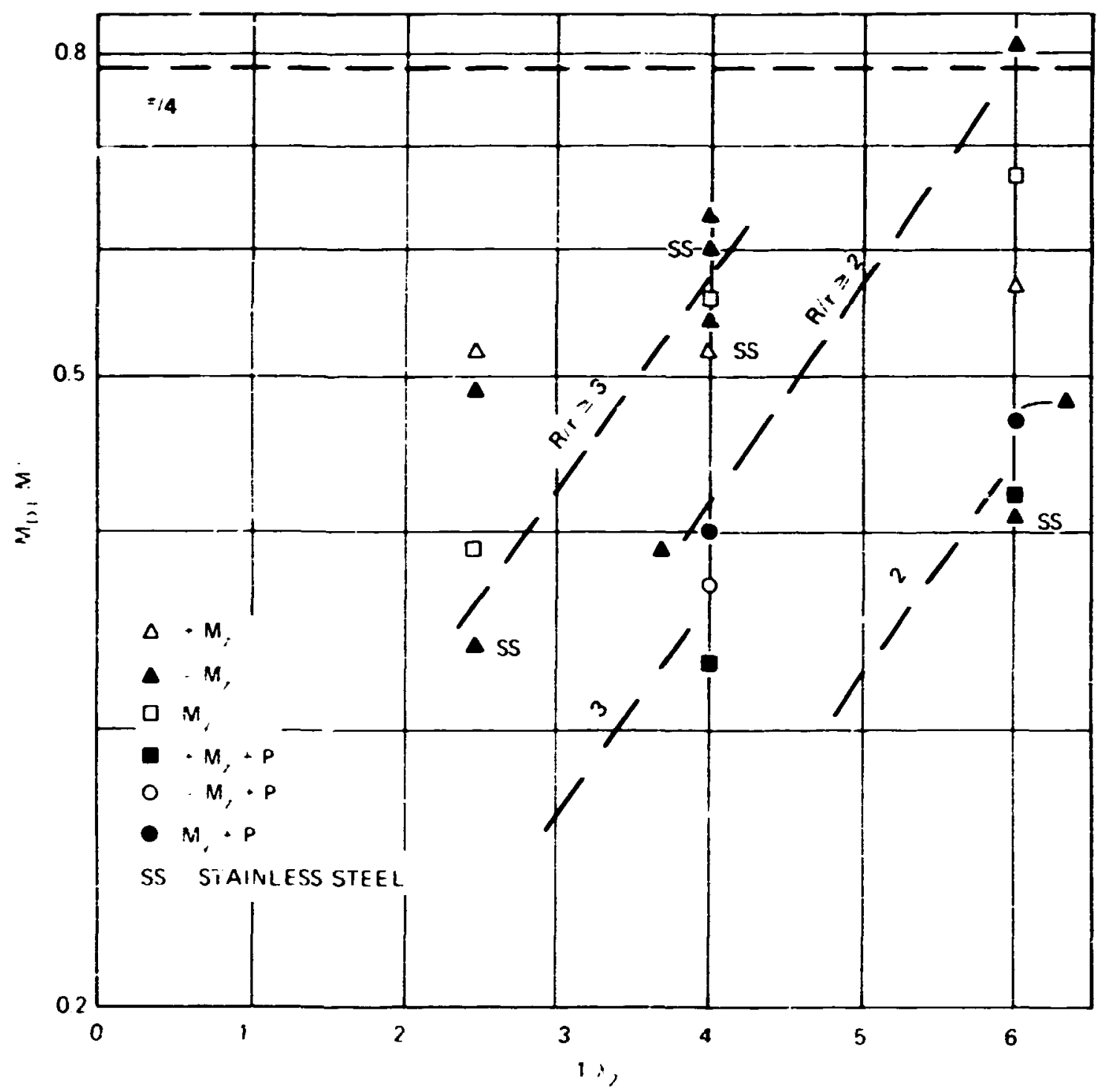

Fig. 36. Moment at onset of nonlinear response as determined from dial-gage readings.

not detected. Hence, the resulting shape factors are low compared to those obtained here; but, altogether, the experimentally determined shape factors from the study by Gross indicate a lack of dependence on in concert with the results given in this report.

The results in the last column of Table $8, M * / M_{0}$, are plotted vs $1 / \lambda_{2}$ in Fig. 37, where the specimen number is given at the left of eacis 


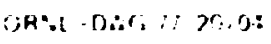

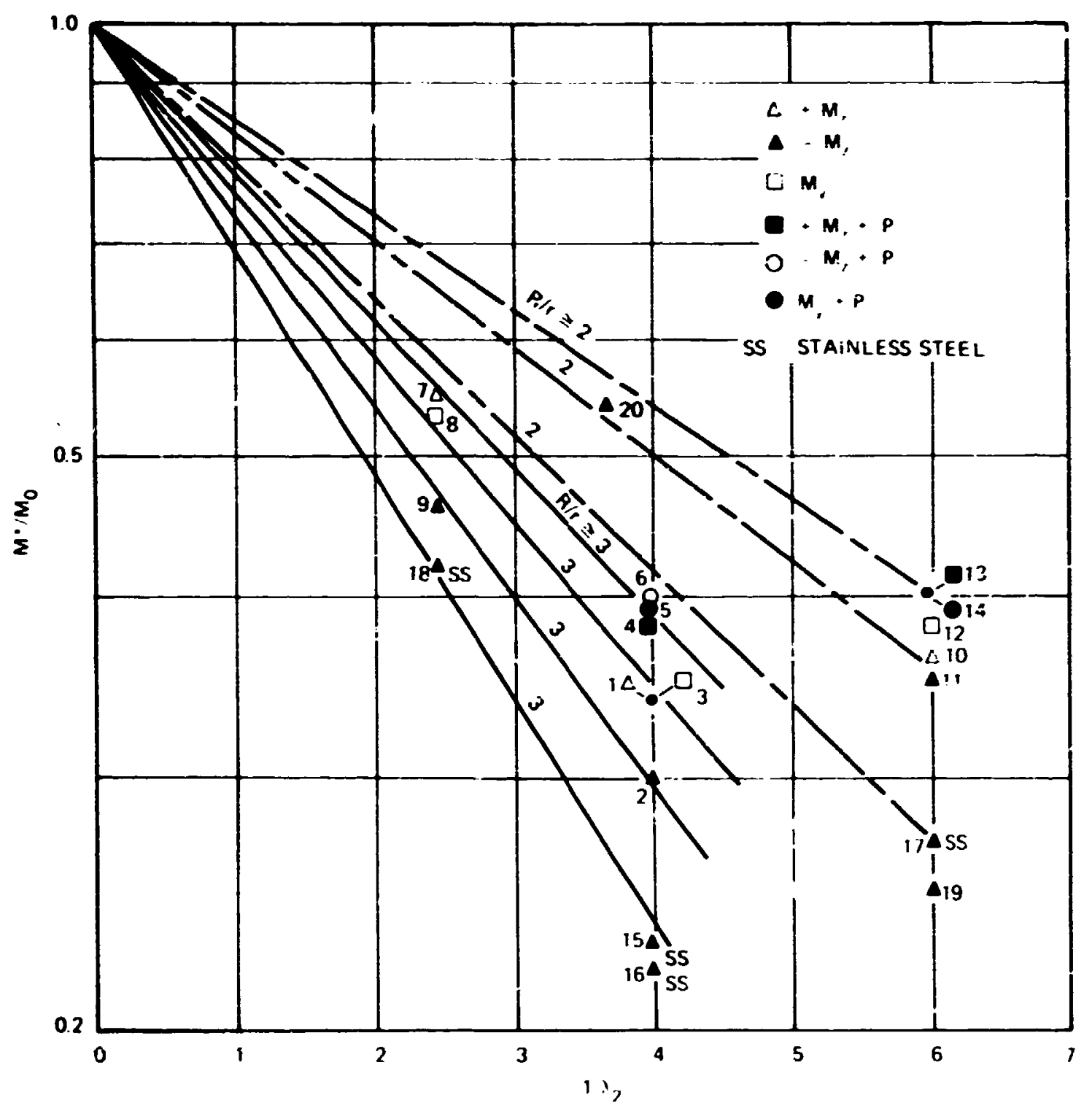

Fig. 37. Normalized plastic collapse moment.

point. By postulating that the results for straight pipe encompass all $R / r$ values, a fan of straight lines emanating from ulity at $1 / \lambda_{2}=0$ has been used for data examination. From Fig. 37, it is seen that the data may be correlated on the basis of $R / r$ as defined. In addition to $\lambda$ and $R / \mathbf{r}$ dependence, $M * / M_{0}$ is dependent upon material and loading.

The magnitude of $M * / M_{0}$ decreases as $R / r$ ratio increases, with the values being lowest for stuinless steel. Points for momert loadings 
also appear to lie on a single line for hir: 2 . However, when $R: T$, the results for $M_{z}$ fall below those for $+M_{z}$ and $M_{y}$. Combined loadings give higher $M * / M$ : ratios for both $i$ 'r ratio:. The value of 0.25 for PE-19 $(\therefore=0.167$ and $R / r=1.89)$ is incongruous with the remainder of the data set. but the cause is unknown.

\section{CONCLISIONS}

Experimentally determined coliapse toments for 20 commercial elbows are presented. The data can be interpreted on an overall basis in terms of the ratios of the calculated zaximum elastic binding stresses at collapse to the yield stresses. The trends are identified as foliows: for dn elbow of given wall thickness, radius, ant material under external load alone, the collapse moment is smaller when an in-plane morent $(-1)$, which tends to cause tine bend radius to decrease, is applied thar it is for the other two cases of moment loading studied. The addition of internal pressure for this case gites collapse moments for long-radius sched-40 elbows that are greater than the mements for the other two conbined loading cases studied for this type of specinen. Internal pressure generall: increases the moment at collapse as defined here, although the loa.l at the onse: of nonlinear iesponse is decreased. The ratio of calcul ted stress to yield stress, as iefined in the foregoing, increases with increasing wall thickness. Finally, this ratio increases with decreasing bend radics for a given wall thickness.

Additional conclusions are drawn $b$; considering the ratio of the collapse momen: to the theoretical collaps; moment for straight pipe, $M^{\star} / M_{2}$. These ratios are dependent upon $, R / r, r$ terials, and loading. They decrease with decreasing $\lambda$ and with increasing $R / r$ ratio. They also show that the collapse moment is smaller when an in-plane moment, which tends to cause the radius to decrease, is applicd. Addition of Internal pressure increases the moment ratin; the ratios are less for stainless steel than for carbon steel. Overall, the data show very consistert trends. However, additional studies are required before these results can be considered senerally applicable outside the ranges of the parameters examined. 
The changes in geometry were generally small, although some ovaling of the cross section occurred in each case. The greatest ovaling occurzed In the stainless-steel specimens, giving 9 to $15 \%$ ovality after test.

The results show that the collapse moments for the stainless steel elbows became increasingly smaller than those for carbon steel specimens, which were subjected to the same loading conditions and had the same dimensions, for decreases in the parameter $\lambda$. Although the yield stress is not the only factor in determining the plastic behavior of a structure, the results obtained in this study indicate that the effective yield stress for stainless steel is significantly lower than the value corresponding to 0.27 offset strain.

\section{ACKNOWLEDGMENT}

The author acknowledges with apprectation the assistance of E. C. Rodabaugh of Battelle Columbus Laboratories and S. E. Moore cf ORNL, who provided guidance in establishing this series of tests and help tn interpreting the results. Sincere appreciation is also extended to S. E. Bolt, J. E. Smith, T. S. Hill, J. P. Rudd, and R. Smith of ORNL, who performed the tests; to $"$. G. Dodge for data processing and for stress and strain computations; and to H. D. Curtis for dimensional data.

\section{REFERENCES}

1. H. H. Demir and D. C. Drucker, "An Experimental Study of Cylindrical Shells Under Ring Lnading," pp. 205-20 ir. Progress in Applied Mechanics (The Prager Anniversary Volwone), Macmillan, New York, 1963.

2. S. E. Bolt and W. L. Greenstreet, "Experimental Determinations of Plastic Collapse Loads for P1pe Elbows," ASME Paper 71-PVP-37, 1971.

3. J. P. Denhartog, Advanced Strength of Materials, PP. 234-45, McGraw-H111, New York, 1952.

4. H. L. Greenstreet, S. E. Moore, and R. C. Gwaltney, "Progress Report on Studies in Applied Solld Mechan1cs," ORNL-4576 (August 1970). 
5. R. M. Haythornthwaite, "A More Ratirial Approach to Strain Hardening Data," pp. 201-18 in Engineering Plasticity, ed. by J. Heyman and F. A. Leckie, Cambr'Age University Press, London, 1968.

6. G. Augusti and S. d'Agostino, "Experiments on the Plastic Behavior of Short Steel Cylindrical Shells Subject to Intern:l Pressure," pp. 45-47 in Pressure Vassel Technology Part I, American Society of Mechanical Engineers, New York, 1969.

7. Fernand Ellyin, "Elastic-'lastic Behavior of Intersecting Shells," J. Eng. Mech. Di.., ASCE, 95, 69-94 (February 1969).

8. J. Schroeder, K. R. Srinivasaiah, and P. Graham, "Analysis of Test Data on Branch Connections Exposed to Internal Pressure and/or Extornal Couples," Wel.d. Res. Counc. BuLZ. 200 (November 1974).

9. Fernand Ellyin, "Experimental Investigation of Limit: Loads of Nozzles in Cylindrical Vessels," Weld. Res. Counc. Bull. 219 (September 1976).

10. Fernand Ellyin, "An Experimental Study of Elastic-Plastic Response of Branch Pipe Tee Connections Subjected to Internal Pressure, External Couples and Combined Loadings," Weld. Res. Counc. Bull. 230 (September 1977).

11. S. Palusamy, "Inf luence of External Loads on Pressure-Carrying Capacity of Outlet Connections," ASME Trans., Ser. B, J. Eng. Ind. 95(3), 113-20 (Fetruary 1973).

12. W. G. Dodge and S. E. Moore, "Stress Indices and Flexibility Factors For Moment Loadings on Flbows and Curved Pipe," Weld. Res. Counc. Bull. 179 (December 19/L).

13. E. C. Rodabaugh, "Interpretive Report on Lialt Analysis and Plastic Behavior of Piping Products," Report Submiteed to PVRC Design Division, Task Group on Characterization of Plastic Behavior of Structures, September 1976.

14. N. Gross, "Experiments on Short-Radius Pipe Bends," Proceedinga of Institute of Mechanical Engineers 166(A), 406 (1952). 
Appendix

DIMENSIOALL DATA FOR SPEC IMENS PE-17 THROUGH -20

Dimensional data were obtained prior to and following test cospletion for spectens PE-17 and -20; specimens PE-18 and -19 were weas::red after cesting only. The outside dianeters (OD) and thicknesses (T) are Iisted in Table A-1 together with the locations at which these measurements we:e taken. Also listed are the ovalities, which ranged from a maximum of 1.37 (prior to test) to 14.57 (following test). The thickness deviations ranged from 0.0 to 14.27 of nominal for PE-17,-7.4 to $+22 \%$ for PE-18; -10 to +7.97 for PE-19z; and -11.6 to $+10.2 \%$ for PE-20. All elbow dimensions are within limits given by the applicable manufacturing standard. 


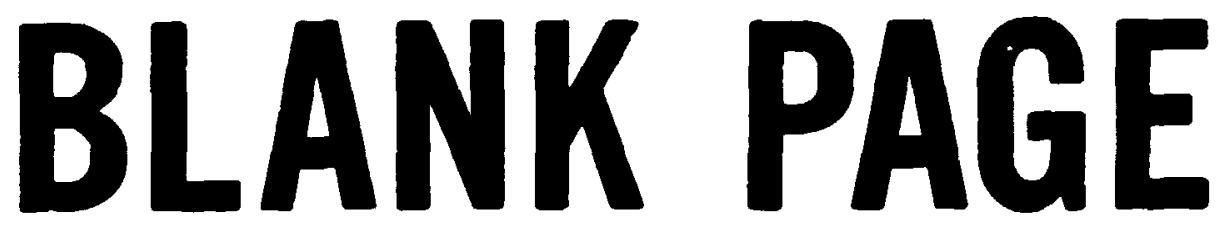


Table A-1. Se quured spectuen dimensions"

\begin{tabular}{|c|c|c|c|c|c|c|c|c|}
\hline \multirow{2}{*}{$\begin{array}{l}\text { Sperituen } \\
\text { ne. }\end{array}$} & \multicolumn{2}{|c|}{ Location } & \multicolumn{2}{|c|}{$\begin{array}{c}\infty \\
(1 r .)\end{array}$} & \multirow{2}{*}{$\begin{array}{l}\text { Location } \\
\text { ansle }\end{array}$} & \multirow{2}{*}{$\frac{\begin{array}{c}T \\
(\leq n .)\end{array}}{\text { Postcest }}$} & \multicolumn{2}{|c|}{$\begin{array}{l}\text { Ovality } \\
\text { (z) }\end{array}$} \\
\hline & Plane & Angle ${ }^{C}$ & Pretent & Postrest & & & Prezest & Posttest \\
\hline \multirow[t]{3}{*}{$P E-17$} & $A$ & $\begin{array}{r}0-180 \\
90-270\end{array}$ & $\begin{array}{l}6.700 \\
6.660\end{array}$ & $\begin{array}{l}6.488 \\
6.848\end{array}$ & $\begin{array}{r}0 \\
90 \\
180 \\
270\end{array}$ & $\begin{array}{l}0.295 \\
0.332 \\
0.296 \\
0.30:\end{array}$ & 0.6 & 5.6 \\
\hline & nid & $\begin{array}{r}0-180 \\
90-270\end{array}$ & $\begin{array}{l}6.575 \\
6.622\end{array}$ & $\begin{array}{l}6.332 \\
0.937\end{array}$ & $\begin{array}{r}0 \\
90 \\
180 \\
270\end{array}$ & $\begin{array}{l}0.250 \\
0.288 \\
0.316 \\
0.278\end{array}$ & 0.7 & 9.3 \\
\hline & - & $\begin{array}{r}0-180 \\
90-2 \div 0\end{array}$ & $\begin{array}{l}6.700 \\
6.625\end{array}$ & $\begin{array}{l}6.460 \\
6.713\end{array}$ & $\begin{array}{r}0 \\
90 \\
180 \\
270\end{array}$ & $\begin{array}{l}0.290 \\
0.298 \\
0.301 \\
0.303\end{array}$ & 1.1 & 4.7 \\
\hline \multirow[t]{3}{*}{ PE-18 } & $A$ & $\begin{array}{r}0-180 \\
90-270\end{array}$ & & $\begin{array}{l}6.423 \\
6.358\end{array}$ & $\begin{array}{r}0 \\
90 \\
180 \\
270\end{array}$ & $\begin{array}{l}0.471 \\
0.477 \\
0.467 \\
0.501\end{array}$ & & 5.1 \\
\hline & Mid & $\begin{array}{r}0-180 \\
90-270\end{array}$ & & $\begin{array}{l}6.105 \\
7.064\end{array}$ & $\begin{array}{r}0 \\
90 \\
180 \\
? 70\end{array}$ & $\begin{array}{l}0.400 \\
0.659 \\
0.514 \\
0.434\end{array}$ & & 14.5 \\
\hline & $L$ & $\begin{array}{r}0-180 \\
90-270\end{array}$ & & $\begin{array}{l}6.477 \\
6.74 i\end{array}$ & $\begin{array}{r}0 \\
90 \\
180 \\
270\end{array}$ & $\begin{array}{l}0.514 \\
0.525 \\
0.455 \\
0.494\end{array}$ & & 4.2 \\
\hline \multirow[t]{3}{*}{ tE-19 } & $A$ & $\begin{array}{r}0-180 \\
90-270\end{array}$ & & $\begin{array}{l}6.432 \\
6.820\end{array}$ & $\begin{array}{r}0 \\
90 \\
180 \\
270\end{array}$ & $\begin{array}{l}0.252 \\
0.293 \\
0.285 \\
0.281\end{array}$ & & 5.9 \\
\hline & Mid & $\begin{array}{r}0-180 \\
90-270\end{array}$ & & $\begin{array}{l}6.412 \\
6.920\end{array}$ & $\begin{array}{r}0 \\
90 \\
180 \\
: 70\end{array}$ & $\begin{array}{l}0.252 \\
0.290 \\
0.269 \\
n .270\end{array}$ & & 7.6 \\
\hline & $\mathbf{L}$ & $\begin{array}{r}0-180 \\
90-270\end{array}$ & & $\begin{array}{l}6.471 \\
6.845\end{array}$ & $\begin{array}{r}0 \\
90 \\
180 \\
270\end{array}$ & $\begin{array}{l}0.260 \\
0.273 \\
0.252 \\
0.302\end{array}$ & & 5.6 \\
\hline \multirow[t]{3}{*}{ PE-20 } & $A$ & $\begin{array}{r}0-180 \\
90-120\end{array}$ & $\begin{array}{l}6.640 \\
6.655\end{array}$ & $\begin{array}{l}6.352 \\
6.898\end{array}$ & $\begin{array}{r}0 \\
90 \\
180 \\
270\end{array}$ & $\begin{array}{l}0.386 \\
0.458 \\
0.443 \\
0.450\end{array}$ & 0.1 & 8.2 \\
\hline & Mid & $\begin{array}{r}0-180 \\
90-120\end{array}$ & $\begin{array}{l}6.566 \\
6.653\end{array}$ & $\begin{array}{l}6.199 \\
7.035\end{array}$ & $\begin{array}{r}0 \\
90 \\
180 \\
270\end{array}$ & $\begin{array}{l}0.383 \\
0.437 \\
0.423 \\
0.44 n\end{array}$ & 1.3 & 12.6 \\
\hline & $L$ & $\begin{array}{r}0-180 \\
90-120\end{array}$ & $\begin{array}{l}6.624 \\
6.647\end{array}$ & $\begin{array}{l}6.410 \\
6.824\end{array}$ & $\begin{array}{r}0 \\
90 \\
180 \\
270\end{array}$ & $\begin{array}{l}r .382 \\
0.450 \\
0.383 \\
0.457\end{array}$ & 0.4 & b.j \\
\hline
\end{tabular}

